\title{
RELAP-7 Input Manual
}

\section{David Andrs, Joshua Hansel, Russell Johns, Richard Martineau, Gregg Swindlehurst}

\section{March 2018}

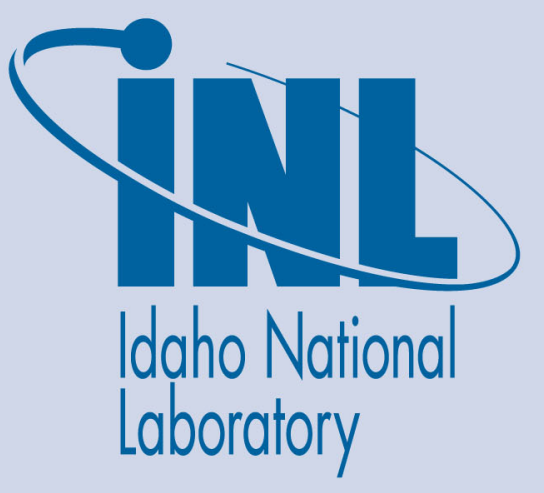

The INL is a U.S. Department of Energy National Laboratory operated by Battelle Energy Alliance 
INL/EXT-18-44979-Revision-0

\section{RELAP-7 Input Manual}

David Andrs, Joshua Hansel, Russell Johns, Richard Martineau, Gregg Swindlehurst

March 2018

Idaho National Laboratory Idaho Falls, Idaho 83415

http://www.inl.gov

Prepared for the

U.S. Department of Energy

Under DOE Idaho Operations Office

Contract DE-AC07-05ID14517 


\title{
RELAP-7 Input Manual
}

\author{
Gregg Swindlehurst \\ David Andrs \\ Joshua Hansel \\ Russell Johns \\ Richard Martineau
}

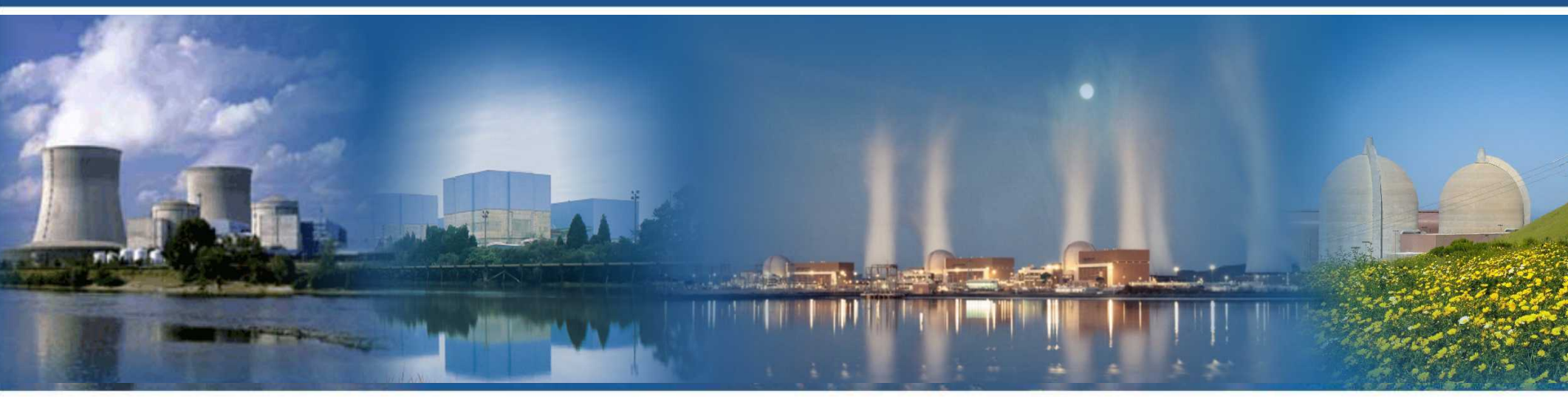

March 2018 


\section{DISCLAIMER}

This information was prepared as an account of work sponsored by an agency of the U.S. Government. Neither the U.S. Government nor any agency thereof, nor any of their employees, makes any warranty, expressed or implied, or assumes any legal liability or responsibility for the accuracy, completeness, or usefulness, of any information, apparatus, product, or process disclosed, or represents that its use would not infringe privately owned rights. References herein to any specific commercial product, process, or service by trade name, trade mark, manufacturer, or otherwise, does not necessarily constitute or imply its endorsement, recommendation, or favoring by the U.S. Government or any agency thereof. The views and opinions of authors expressed herein do not necessarily state or reflect those of the U.S. Government or any agency thereof. 
RELAP-7 Input Manual

Gregg Swindlehurst, David Andrs, Joshua Hansel, Russell Johns, Richard Martineau

March 2018

\section{Idaho National Laboratory Idaho Falls, Idaho 83415}

http://www.inl.gov

Prepared for the

U.S. Department of Energy

Office of Nuclear Energy

Under DOE Idaho Operations Office

Contract DE-AC07-05ID14517 


\section{Table of Contents}

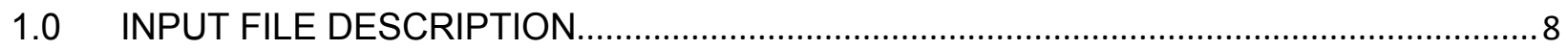

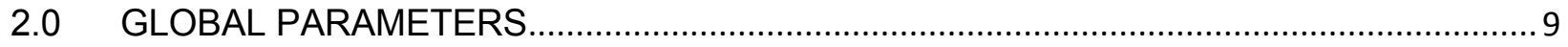

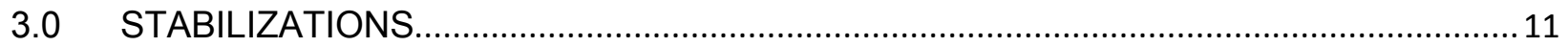

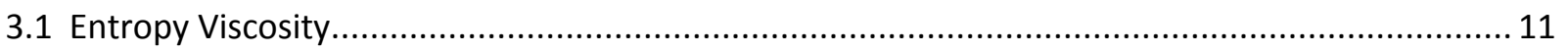

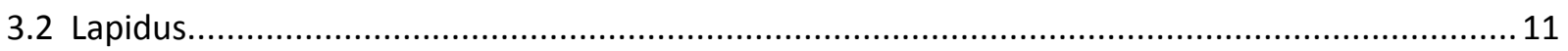

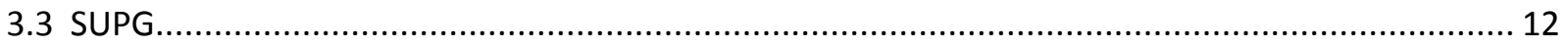

3.4 Pressure

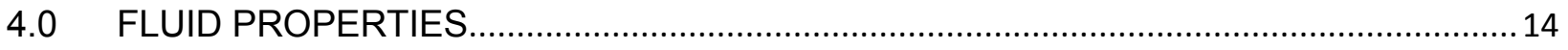

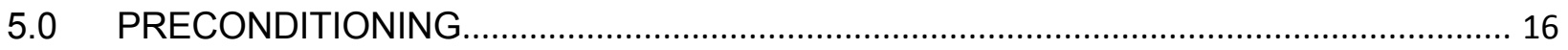

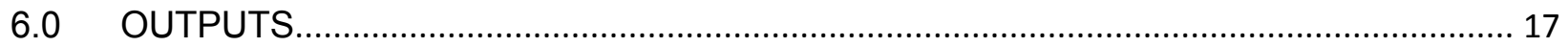

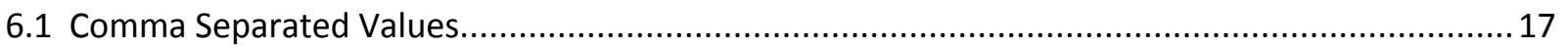

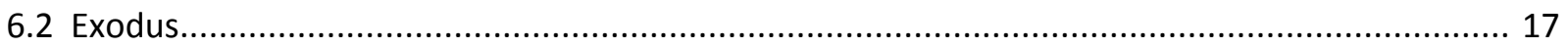

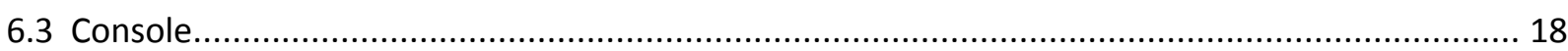

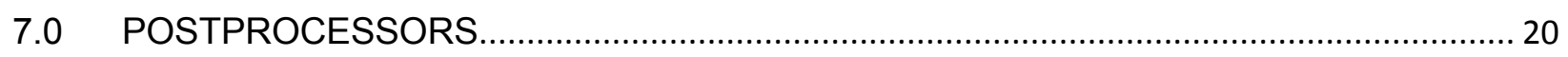

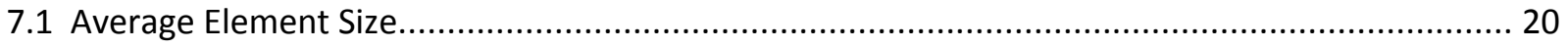

7.2 Average Nodal Variable Value........................................................................................... 21

7.3 Change Over Time Step................................................................................................. 21

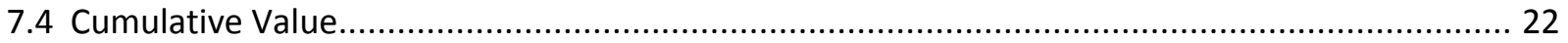

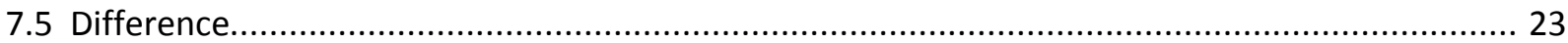

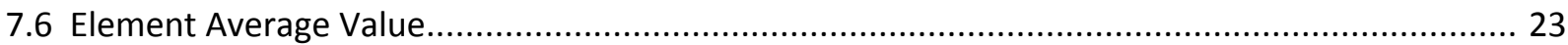

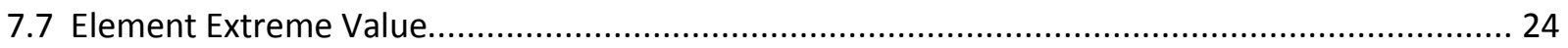

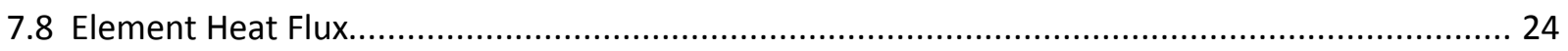

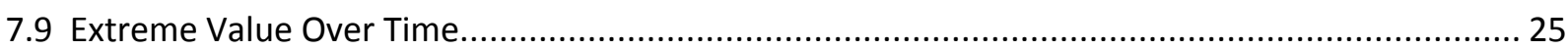

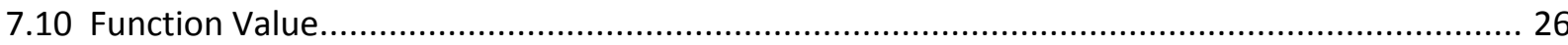

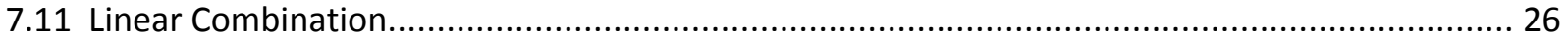

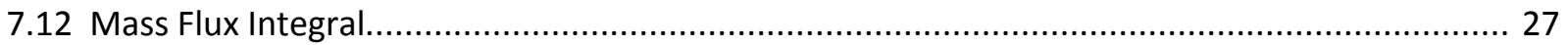

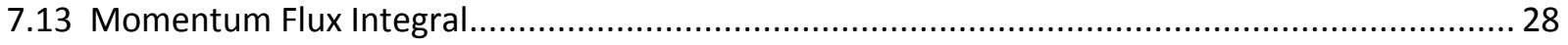

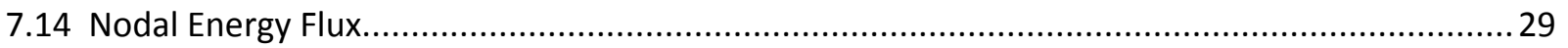

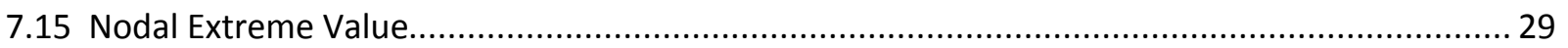

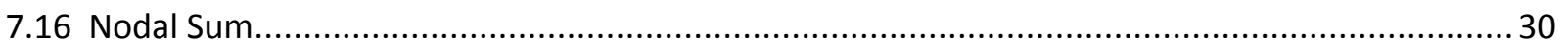

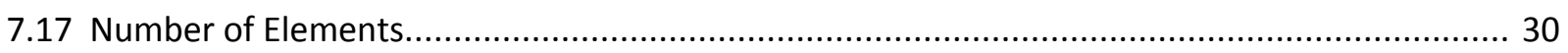




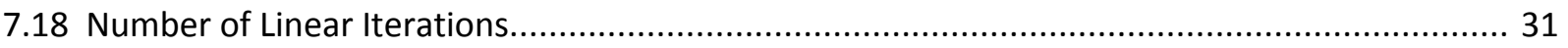

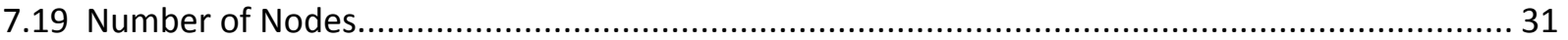

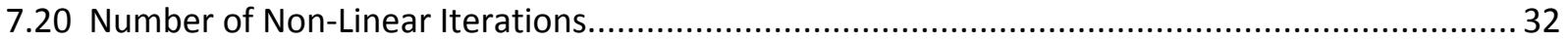

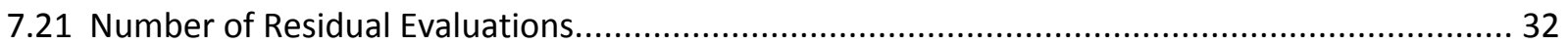

7.22 Point Value

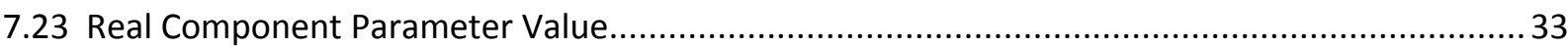

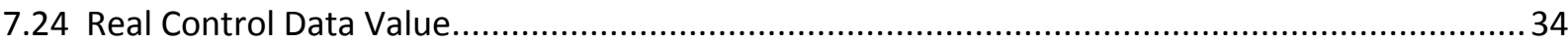

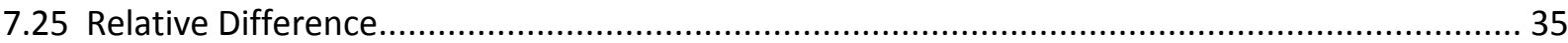

7.26 Scalar Variable

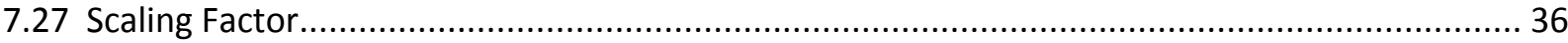

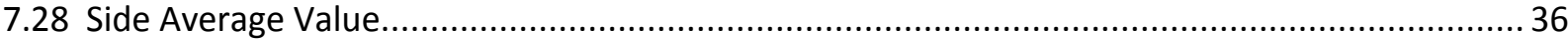

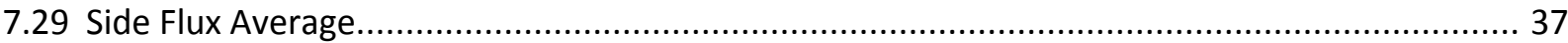

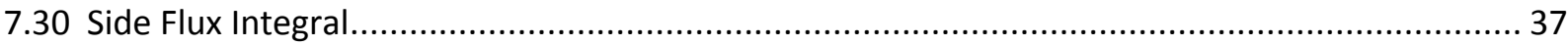

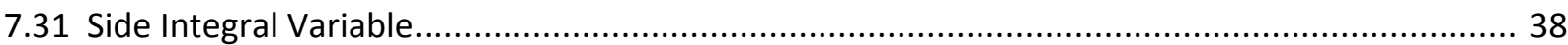

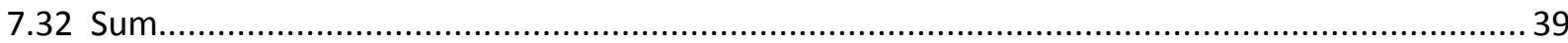

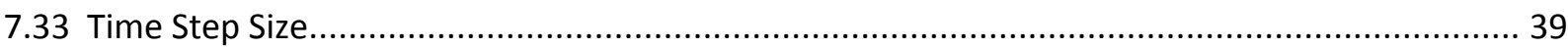

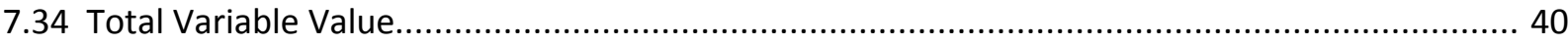

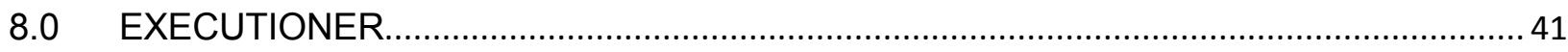

8.1 Transient

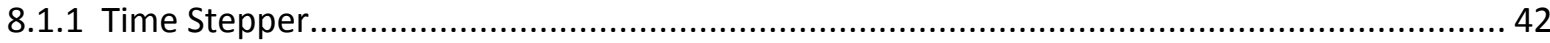

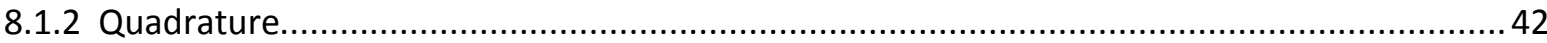

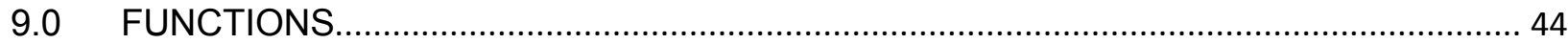

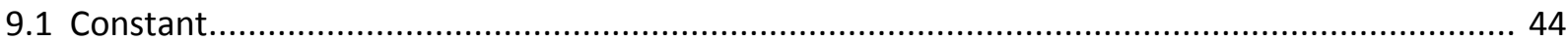

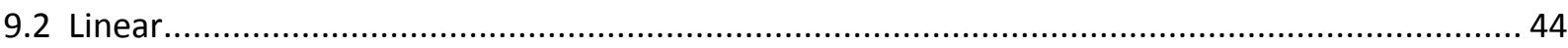

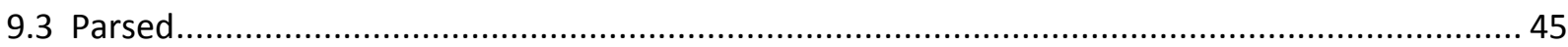

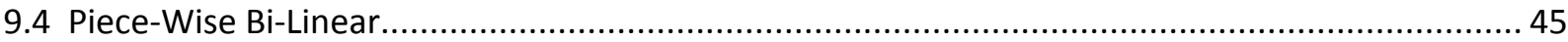

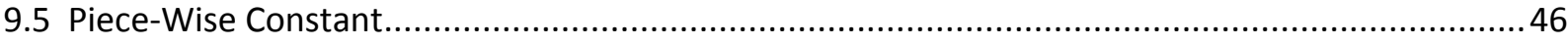

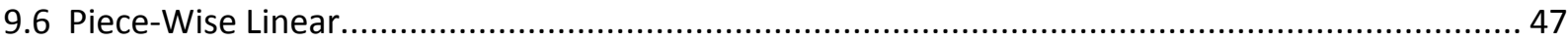

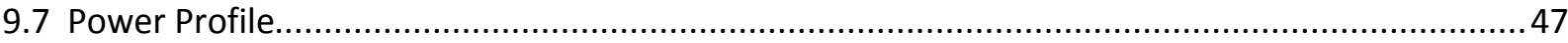

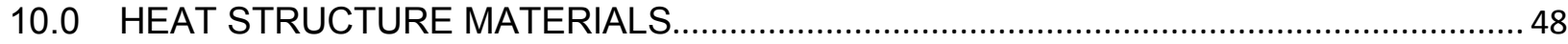

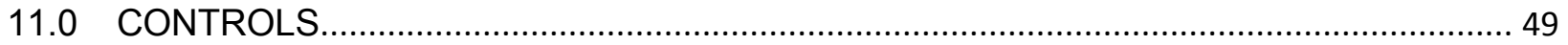

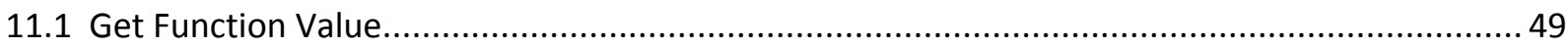

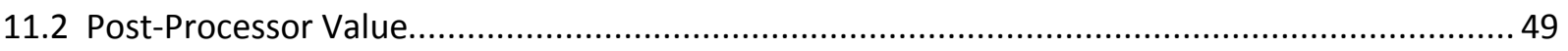




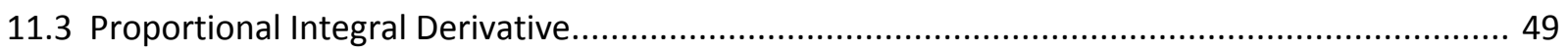

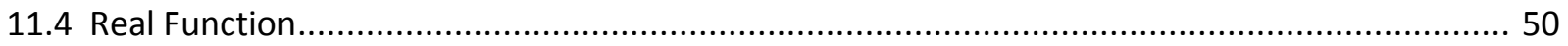

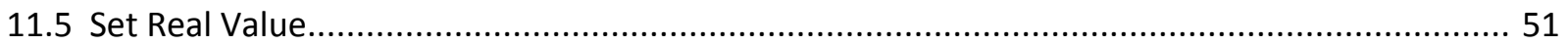

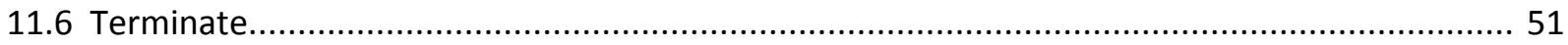

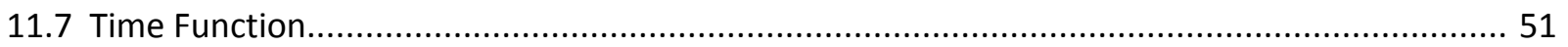

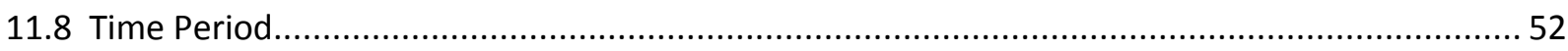

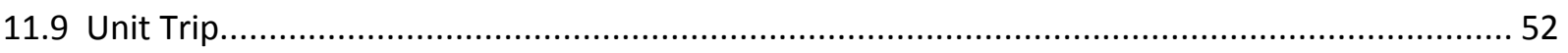

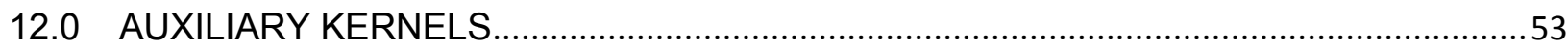

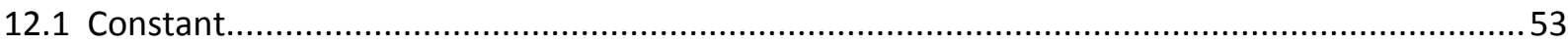

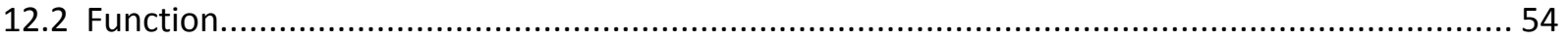

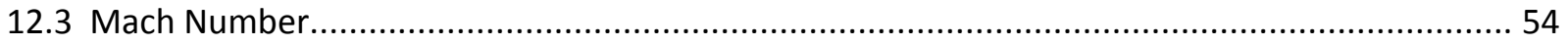

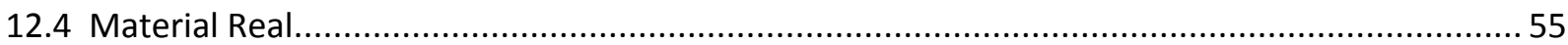

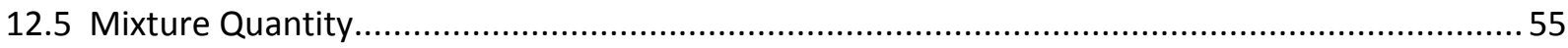

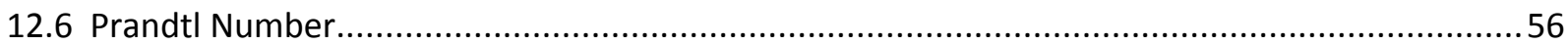

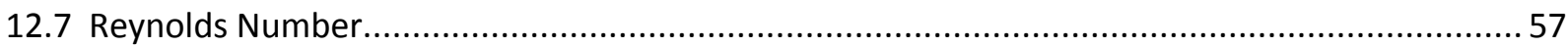

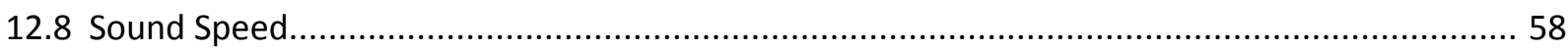

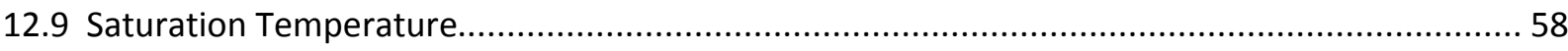

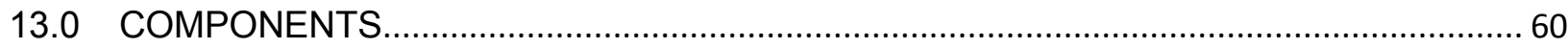

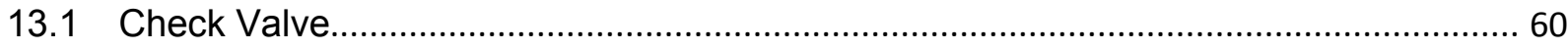

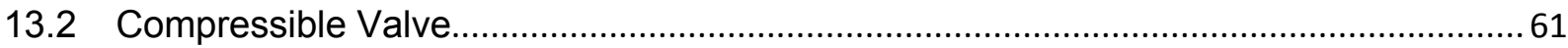

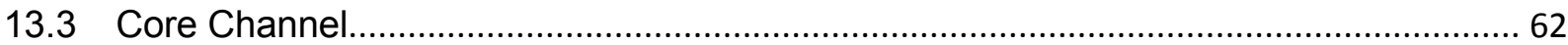

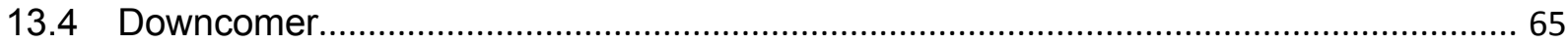

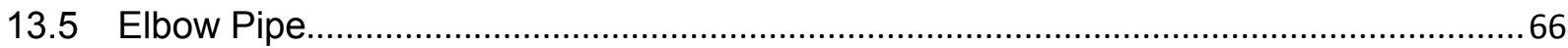

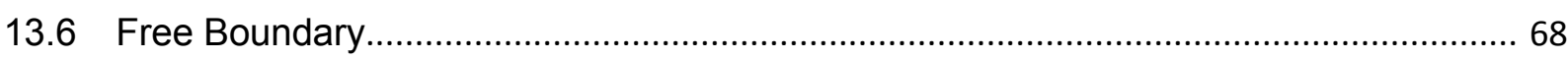

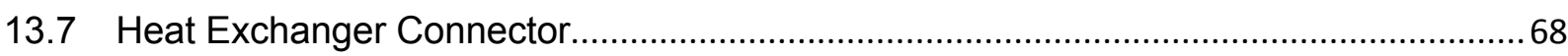

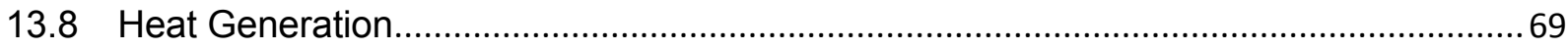

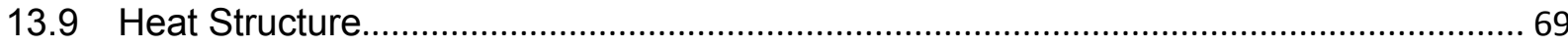

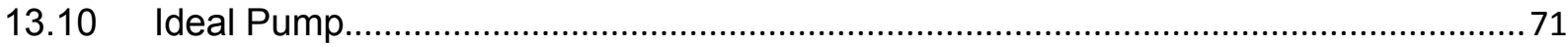

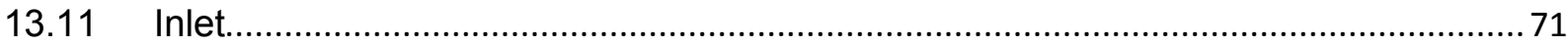

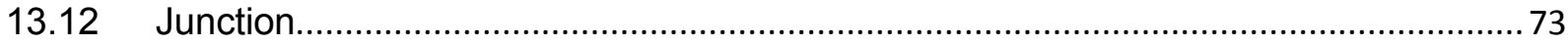

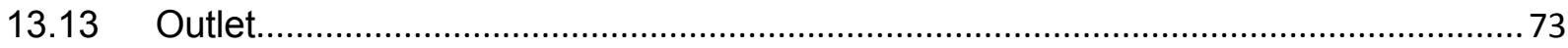

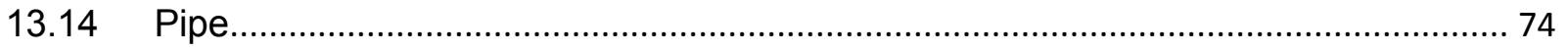

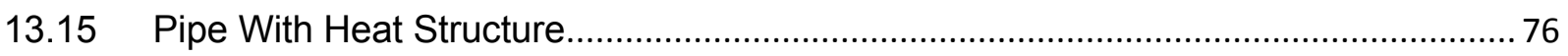




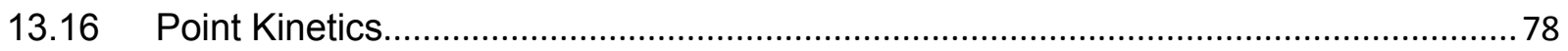

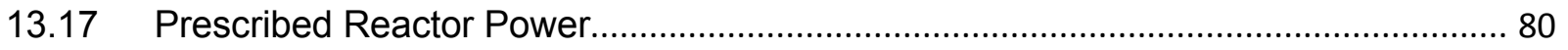

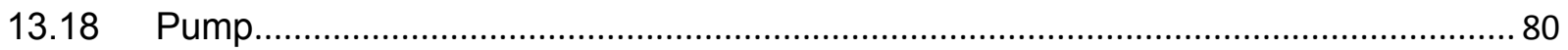

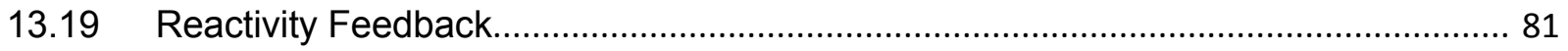

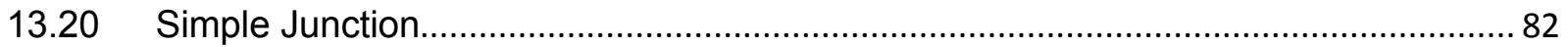

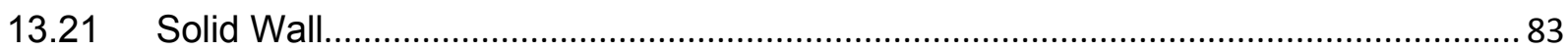

13.22 Turbine

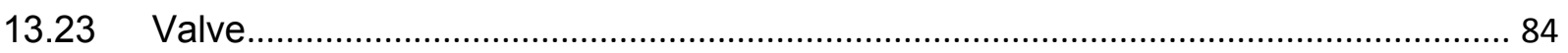

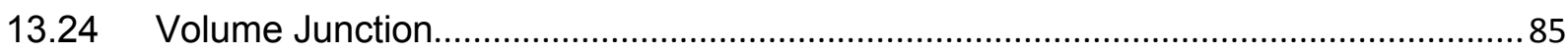

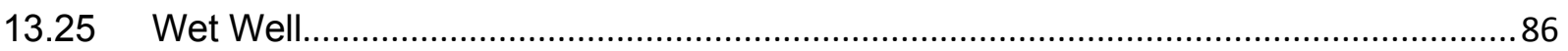




\section{SUMMARY}

The RELAP-7 code is the next generation nuclear reactor system safety analysis code being developed at the Idaho National Laboratory (INL). The code is based on the INL's modern scientific software development framework, MOOSE (Multi-Physics Object Oriented Simulation Environment). The overall design goal of RELAP-7 is to take advantage of the previous thirty years of advancements in computer architecture, software design, numerical integration methods, and physical models. The end result will be a reactor systems analysis capability that retains and improves upon RELAP5's capability and extends the analysis capability for all reactor system simulation scenarios.

RELAP-7 will be the next generation tool in the RELAP reactor safety/systems analysis application series. The key to the success of RELAP-7 is the simultaneous advancement of physical models, numerical methods, and software design while maintaining a solid user perspective. Physical models include both PDEs (Partial Differential Equations) and ODEs (Ordinary Differential Equations) and experimental based closure models. RELAP-7 utilizes wellposed governing equations for compressible two-phase flow, which can be strictly verified in a modern verification and validation effort. Closure models used in the TRACE code have been selected to reflect the progress made during the past three decades. RELAP-7 uses modern numerical methods, which allow implicit time integration, second-order schemes in both time and space, and strongly coupled multi-physics.

RELAP-7 is written with object oriented programming language $\mathrm{C}++$. By using the MOOSE development environment, the RELAP-7 code is developed by following the same modern software design paradigms used for other MOOSE development efforts. The code is easy to read, develop, maintain, and couple with other codes. Most importantly, the modern software design allows the RELAP-7 code to evolve efficiently with time. MOOSE is an HPC development and runtime framework for solving computational engineering problems in a well planned, managed, and coordinated way. By leveraging millions of lines of open source software packages, such as PETSc (a nonlinear solver developed at Argonne National Laboratory) and LibMesh (a Finite Element Analysis package developed at University of Texas), MOOSE reduces the expense and time required to develop new applications. MOOSE provides numerical integration methods and mesh management for parallel computation. Therefore RELAP-7 code developers have been able to focus more upon the physics and user interface capability. There are currently over 20 different MOOSE based applications ranging from 3-D transient neutron transport, detailed 3-D transient fuel performance analysis, to long-term material aging. Multiphysics and multi-dimensional analysis capabilities, such as radiation transport and fuel performance, can be obtained by coupling RELAP-7 and other MOOSE-based applications through MOOSE and by leveraging with capabilities developed by other DOE programs. This allows restricting the focus of RELAP-7 to systems analysis type simulations and gives priority to retain and significantly extend RELAP5's capabilities. 
This RELAP-7 Input Manual provides the users with a description of the input parameters for which character strings or numerical values are provided to build a RELAP-7 input file. Some of the input parameters are required for any RELAP-7 input file, and many others represent optional input file parameters that can be provided at the discretion of the user. Some of the input parameters have default values that can be superseded by user specified values.

The RELAP-7 Theory Manual describes the theoretical basis, the development of the equations and models used in the simulation, and the numerical solution methods. The RELAP-7 User's Guide focuses on assisting users in developing input models by use of a progression of sample problems of increasing complexity. These two manuals, in concert with this RELAP-7 Input Manual, provide the necessary information to apply the RELAP-7 code to system thermalhydraulic analysis. 


\subsection{INPUT FILE DESCRIPTION}

RELAP-7 uses a block-structured input file syntax, with each block having a standard name to indicate the required and optional input data. Each block name is identified with brackets ("[standard name]") at the beginning of the block, and empty brackets ("[ ]") at the end.

Some input file blocks may contain sub-blocks identified similarly with ("[./name]"at the beginning of the sub-block and "[../]") at the end. Each sub-block must have an unique name (i.e. cannot use reserved names such as 'pipe' - e.g. need to use 'pipeXX") when compared with all other subblocks in each specified block. Each sub-block also has a standard type identified with ("type = standard name") to indicate the sub-block specific input file parameters.

Input files are generally specified using syntax that consists of parameter and value pairs with an "equal sign" between them. The parameter is a block-specific and sub-block-specific standard string, and the value may be a string, an integer, a real number, or a list of strings, integers, or real numbers. Lists are given in single quotes and are separated by whitespace.

If a "parameter = value" pair is repeated in the input file, then the last appearance will be used.

Comment text is preceded by a hash symbol ("\#") in the input file.

RELAP-7 uses SI units for all input file parameters.

The open source "Atom" editor (https://atom.io) is recommended for editing RELAP-7 input files as it has plugins that assist with input file creation and editing. Drop-downs of parameter lists show the available parameters, the required parameters, default values, and parameter descriptions.

The following report sections have detailed descriptions of input file parameters for each input file block, and for commonly used sub-blocks. Additional parameters that are not commonly used are not included in the table. A file with a complete list of RELAP-7 input file parameters can be obtained via the command (". /relap-7-opt -dump >filename"). 


\subsection{GLOBAL PARAMETERS}

The global parameters [GlobalParams] block includes those input parameters used by RELAP-7 that can specified generically, such as the choice of stabilization scheme to be used in the numerical solution, and the initial values of pressure, velocity, and temperature of the system being modeled. The generic parameter values specified in the global parameters block are used throughout the model unless they are superseded by specifying those same parameters in any block or subblock. None of the parameters are required. Typically, any input that can be specified generically or mostly generically are included in the [GlobalParams] block to reduce the volume of the input file.

In the following table the input file parameters for the [GlobalParams] block are listed.

\begin{tabular}{|c|c|c|}
\hline $\begin{array}{l}\text { Input File Parameters } \\
\text { (Note: None are required but } \\
\text { those that are typically } \\
\text { specified are bolded) }\end{array}$ & $\begin{array}{c}\text { Parameter Values } \\
\text { (Note: Defaults are bolded) }\end{array}$ & Description \\
\hline alpha_vapor_bounds & '0.0001 0.9999' & $\begin{array}{l}\text { Lower and upper bounds imposed } \\
\text { on the vapor volume fraction. } \\
\text { Non-zero values are required. }\end{array}$ \\
\hline chf_table & aecl-ippe-1995 & $\begin{array}{l}\text { The lookup table used for critical } \\
\text { heat flux. The AECL/IPPE } 1995 \\
\text { table is the default. }\end{array}$ \\
\hline closures_type & simple & $\begin{array}{l}\text { The 'trace' closures are } \\
\text { recommended for water. Another } \\
\text { option is 'helium'. }\end{array}$ \\
\hline gravity & 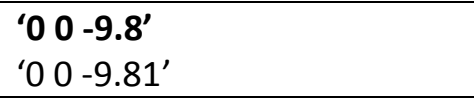 & $\begin{array}{l}\text { The standard }(x, y, z) \text { gravity } \\
\text { vector '0 } 0-9.81 \text { ' is recommended }\end{array}$ \\
\hline heat_exchange_coef_liquid & & $\begin{array}{l}\text { A constant heat transfer } \\
\text { coefficient for liquid if closures } \\
\text { not used }\end{array}$ \\
\hline heat_exchange_coef_vapor & & $\begin{array}{l}\text { A constant heat transfer } \\
\text { coefficient for vapor if closures } \\
\text { not used }\end{array}$ \\
\hline initial_T & & $\begin{array}{l}\text { Initial temperature for fluid if } \\
\text { single-phase fluid properties used }\end{array}$ \\
\hline initial_T_liquid & & Initial temperature for liquid \\
\hline initial_T_vapor & & Initial temperature for vapor \\
\hline initial_alpha_vapor & & $\begin{array}{l}\text { Initial vapor volume fraction for } \\
\text { fluid }\end{array}$ \\
\hline initial_p & & Initial pressure for fluid if single- \\
\hline
\end{tabular}




\begin{tabular}{|l|l|l|}
\hline & & phase fluid properties used \\
\hline initial_p_liquid & & Initial pressure for liquid \\
\hline initial_p_vapor & & Initial pressure for vapor \\
\hline initial_vel & & $\begin{array}{l}\text { Initial velocity for fluid if single- } \\
\text { phase fluid properties used }\end{array}$ \\
\hline initial_vel_liquid & Initial velocity for liquid \\
\hline initial_vel_vapor & true & Initial velocity for vapor \\
\hline interface_transfer & $\begin{array}{l}\text { Interface heat and mass transfer } \\
\text { on }\end{array}$ \\
\hline stabilization & $\begin{array}{l}\text { User-selected name of the } \\
\text { stabilization option specified in } \\
\text { the Stabilizations block. }\end{array}$ \\
\hline wall_mass_transfer & $\begin{array}{l}\text { Turns on the wall boiling model } \\
\text { and is recommended }\end{array}$ \\
\hline
\end{tabular}




\subsection{STABILIZATIONS}

The stabilizations [Stabilizations] block creates the stabilization options that can be selected by the GlobalParams block or by Pipe components to stabilize the numerical solution method used in RELAP-7. The stabilization options can differ with regard to the applicability to single-phase or two-phase conditions. More than one option can be created for subsequent selection in the same input file.

Other stabilization options are included in RELAP-7 but are not specified here.

In the following sections the input file parameters that typically require values to be entered (e.g. required and no default values) for each of the [Stabilizations] sub-blocks are listed.

\subsection{Entropy Viscosity}

\begin{tabular}{|l|l|l|}
\hline \multicolumn{1}{|c|}{$\begin{array}{c}\text { Input File Parameters } \\
\text { (Note: Required are bolded) }\end{array}$} & \multicolumn{1}{|c|}{ Parameter Values } \\
\hline [./name] & Unique name & \multicolumn{1}{c|}{ Description } \\
\hline type & EntropyViscosity & $\begin{array}{l}\text { The entropy viscosity option is } \\
\text { applicable to single or two-phase } \\
\text { conditions }\end{array}$ \\
\hline use_first_order & false & $\begin{array}{l}\text { 'true" means a first-order scheme } \\
\text { is used. 'false' means the second- } \\
\text { order scheme is used and is the } \\
\text { default and recommended. }\end{array}$ \\
\hline
\end{tabular}

\subsection{Lapidus}

\begin{tabular}{|c|c|c|}
\hline $\begin{array}{l}\text { Input File Parameters } \\
\text { (Note: Required are bolded) }\end{array}$ & $\begin{array}{c}\text { Parameter Values } \\
\text { (Note: Defaults are bolded) }\end{array}$ & Description \\
\hline$[. /$ name $]$ & Unique name & Designates sub-block name \\
\hline type & Lapidus & $\begin{array}{l}\text { The Lapidus option is applicable to } \\
\text { single or two-phase conditions }\end{array}$ \\
\hline $\mathrm{cl}$ & $\begin{array}{l}\mathbf{1} \\
\text { (zero to 2) }\end{array}$ & $\begin{array}{l}\text { Coefficient for single phase. } \\
\text { Recommended values range from } \\
\text { zero to } 2 \text { with a default value of } 1 .\end{array}$ \\
\hline cl_liquid & $\begin{array}{l}1 \\
\text { (zero to } 2 \text { ) }\end{array}$ & $\begin{array}{l}\text { Coefficient for liquid phase. } \\
\text { Recommended values range from }\end{array}$ \\
\hline
\end{tabular}




\begin{tabular}{|l|l|l|}
\hline cl_vapor & $\begin{array}{l}\text { zero to 2 with a default value of } 1 . \\
\text { (zero to 2) }\end{array}$ & $\begin{array}{l}\text { Coefficient for vapor phase. } \\
\text { Recommended values range from } \\
\text { zero to 2 with a default value of 1. }\end{array}$ \\
\hline use_first_order & false & $\begin{array}{l}\text { 'true" means a first-order scheme } \\
\text { is used. 'false' means the second- } \\
\text { order scheme is used and is the } \\
\text { default and recommended. }\end{array}$ \\
\hline
\end{tabular}

\subsection{SUPG}

\begin{tabular}{|l|l|l|}
\hline \multicolumn{1}{|c|}{ Input File Parameters } & \multicolumn{1}{|c|}{ Parameter Values } & \multicolumn{1}{c|}{ Description } \\
(Note: Required are bolded) & (Note: Defaults are bolded) & Designates sub-block name \\
\hline [./name] & Unique name & $\begin{array}{l}\text { The Streamline Upwind Petrov } \\
\text { Galerkin (SUPG) option is } \\
\text { applicable to single-phase } \\
\text { conditions }\end{array}$ \\
\hline
\end{tabular}

\subsection{Pressure}

\begin{tabular}{|c|c|c|}
\hline $\begin{array}{l}\text { Input File Parameters } \\
\text { (Note: Required are bolded) }\end{array}$ & $\begin{array}{c}\text { Parameter Values } \\
\text { (Note: Defaults are bolded) }\end{array}$ & Description \\
\hline$[. /$ name $]$ & Unique name & Designates sub-block name \\
\hline type & StabilizationPressure & $\begin{array}{l}\text { The stabilization pressure option is } \\
\text { applicable to single-and two-phase } \\
\text { conditions }\end{array}$ \\
\hline order & & $\begin{array}{l}\text { 'FIRST' means dissipation is } \\
\text { added according to the first } \\
\text { derivative (gradient) of } \\
\text { pressure. 'SECOND' means } \\
\text { dissipation is added according to } \\
\text { the second derivative } \\
\text { (curvature) of pressure. }\end{array}$ \\
\hline ce & $\begin{array}{l}\mathbf{1 . 5} \\
\text { (zero to 2) }\end{array}$ & $\begin{array}{l}\text { Coefficient for single phase. } \\
\text { Recommended values range from } \\
\text { zero to } 2 \text { with a default value of }\end{array}$ \\
\hline
\end{tabular}




\begin{tabular}{|c|c|c|}
\hline & & 1.5. \\
\hline ce_liquid & $\begin{array}{l}\mathbf{0 . 5} \\
\text { (zero to 2) }\end{array}$ & $\begin{array}{l}\text { Coefficient for liquid phase. } \\
\text { Recommended values range from } \\
\text { zero to } 2 \text { with a default value of } \\
0.5 \text {. }\end{array}$ \\
\hline ce_vapor & $\begin{array}{l}\mathbf{0 . 5} \\
\text { (zero to 2) }\end{array}$ & $\begin{array}{l}\text { Coefficient for vapor phase. } \\
\text { Recommended values range from } \\
\text { zero to } 2 \text { with a default value of } \\
0.5 \text {. }\end{array}$ \\
\hline
\end{tabular}




\subsection{FLUID PROPERTIES}

The fluid properties [FluidProperties] block creates sub-blocks of various fluid properties coded in RELAP7 (e.g. water, air/water, helium, or nitrogen) that can then be referencedin other blocks by components including fluid. For water the IAPWS 95 water properties are used. In addition, if only the liquid or steam phase is present, the IAPWS 95 water properties for either single phase can be specified for computational efficiency, but are not necessary.

Properties for other fluids, such as sodium or an ideal gas, are included in RELAP-7 but are not specified here.

In the following table the input file parameters for the [FluidProperties] sub-blocks are listed.

\begin{tabular}{|c|c|c|}
\hline $\begin{array}{l}\text { Input File Parameters } \\
\text { (Note: Required are bolded) }\end{array}$ & $\begin{array}{c}\text { Parameter Values } \\
\text { (Note: Defaults are bolded) }\end{array}$ & Description \\
\hline \multicolumn{3}{|c|}{ IAPWS95 7 Equation Fluid Properties } \\
\hline [./name] & Unique name & $\begin{array}{l}\text { Designates sub-block component } \\
\text { name }\end{array}$ \\
\hline type & $\begin{array}{l}\text { IAPWS957EqnFluidPropertie } \\
\text { s }\end{array}$ & $\begin{array}{l}\text { This option is typically used for } \\
\text { water properties as it is applicable } \\
\text { to two-phase conditions }\end{array}$ \\
\hline \multicolumn{3}{|l|}{ IAPWS95 Liquid Properties } \\
\hline [./name] & Unique name & $\begin{array}{l}\text { Designates sub-block component } \\
\text { name }\end{array}$ \\
\hline type & IAPWS95LiquidProperties & $\begin{array}{l}\text { This option can be used if only } \\
\text { liquid phase water is modeled }\end{array}$ \\
\hline \multicolumn{3}{|l|}{ IAPWS95 Vapor Properties } \\
\hline [./name] & Unique name & $\begin{array}{l}\text { Designates sub-block component } \\
\text { name }\end{array}$ \\
\hline type & IAPWS957VaporProperties & $\begin{array}{l}\text { This option can be used if only } \\
\text { vapor phase water is modeled }\end{array}$ \\
\hline \multicolumn{3}{|c|}{ Air/Water 7 Equation Fluid Properties } \\
\hline [./name] & Unique name & $\begin{array}{l}\text { Designates sub-block component } \\
\text { name }\end{array}$ \\
\hline type & $\begin{array}{l}\text { Air/Water7EqnFluidProperti } \\
\text { es }\end{array}$ & $\begin{array}{l}\text { This option can be used if an } \\
\text { air/water problem is modeled }\end{array}$ \\
\hline
\end{tabular}




\section{Helium Fluid Properties}

\begin{tabular}{|l|l|l|}
\hline [./name] & Unique name & $\begin{array}{l}\text { Designates sub-block component } \\
\text { name }\end{array}$ \\
\hline type & HeliumFluidProperties & $\begin{array}{l}\text { Specifies helium gas properties for } \\
\text { an ideal gas model }\end{array}$ \\
\hline $\mathbf{R}$ & 2076.9 & Gas constant \\
\hline beta & & Coefficient of thermal expansion \\
\hline gamma & .667 & gamma value $(\mathrm{cp} / \mathrm{cv})$ \\
\hline $\mathrm{k}$ & & Thermal conductivity \\
\hline $\mathrm{mu}$ & & Dynamic viscosity \\
\hline
\end{tabular}

Nitrogen Fluid Properties

\begin{tabular}{|l|l|l|}
\hline [./name] & Unique name & $\begin{array}{l}\text { Designates sub-block component } \\
\text { name }\end{array}$ \\
\hline type & N2FluidProperties & $\begin{array}{l}\text { Specifies nitrogen gas properties } \\
\text { for an ideal gas model }\end{array}$ \\
\hline chi_cp & $\mathbf{1}$ & $\begin{array}{l}\text { Uncertainty coefficient on specific } \\
\text { heat at constant pressure }\end{array}$ \\
\hline chi_k & $\mathbf{1}$ & $\begin{array}{l}\text { Uncertainty coefficient on thermal } \\
\text { conductivity }\end{array}$ \\
\hline chi_mu & $\mathbf{1}$ & Uncertainty coefficient on viscosity \\
\hline chi_p & $\mathbf{1}$ & Uncertainty coefficient on pressure \\
\hline
\end{tabular}




\subsection{PRECONDITIONING}

The preconditioning block [Preconditioning] specifies the preconditioner to be used by the RELAP-7 code. The single matrix preconditioner (SMP) is the recommended option.

Other preconditioners and options are included in RELAP-7 but are not specified here.

In the following table the Input File Parameters for the SMP preconditioner sub-blocks is listed.

\begin{tabular}{|l|l|l|}
\hline \multicolumn{1}{|c|}{ Input File Parameters } & \multicolumn{1}{|c|}{ Parameter Values } & \multicolumn{1}{c|}{ Description } \\
\hline [./note: Required are bolded) & (Note: Defaults are bolded) & $\begin{array}{l}\text { Designates sub-block component } \\
\text { name }\end{array}$ \\
\hline type & Unique name & $\begin{array}{l}\text { Designates the recommended single } \\
\text { matrix preconditioner (SMP) }\end{array}$ \\
\hline full & SMP & $\begin{array}{l}\text { True is recommended to obtain the } \\
\text { full set of couplings }\end{array}$ \\
\hline solve_type & $\begin{array}{l}\text { true } \\
\text { false }\end{array}$ & $\begin{array}{l}\text { Preconditioned Jacobian-Free } \\
\text { Newton Krylov (PJFNK) is the } \\
\text { recommended option }\end{array}$ \\
\hline
\end{tabular}




\subsection{OUTPUTS}

The outputs [Outputs] block specifies the RELAP-7 output files that are generated for run-time or postprocessing applications.

Other output options are included in RELAP-7 but are not specified here.

In the following sections the output file format options and parameters for the[Outputs] sub-blocks are listed.

\subsection{Comma Separated Values}

The primary use of the comma separated values (CSV) format output file is for use by the graphical user interface (GUI).

\begin{tabular}{|l|l|l|}
\hline \multicolumn{1}{|c|}{ Input File Parameters } & \multicolumn{1}{|c|}{ Parameter Values } & \multicolumn{1}{c|}{ Description } \\
\hline [./name] & (Note: Defaults are bolded) & Designates sub-block name \\
\hline type & Unique name & $\begin{array}{l}\text { Designate that the output file is in } \\
\text { the comma separated values (CSV) } \\
\text { format }\end{array}$ \\
\hline execute_on & 'initial timestep_end' & $\begin{array}{l}\text { Control the execution of the output } \\
\text { file. Options are to set to } \\
\text { (nonelinitial|linear|nonlinear|time } \\
\text { step_end/timestep_begin|final|fai } \\
\text { led/custom) to execute only at that } \\
\text { moment }\end{array}$ \\
\hline show & $\begin{array}{l}\text { Alist of the variables and } \\
\text { postprocessors that should be } \\
\text { output to the csv file (may include } \\
\text { variables, scalarVariables, and } \\
\text { postprocessor names). }\end{array}$ \\
\hline sync_only & $\begin{array}{l}\text { If true only export results at sync } \\
\text { times that execution and outputs } \\
\text { are forced to occur }\end{array}$ \\
\hline sync_times & $\begin{array}{l}\text { Times at which the output and } \\
\text { solution are forced to occur }\end{array}$ \\
\hline
\end{tabular}

\subsection{Exodus}

The primary use of the exodus output file is for use by the Paraview post-processor.

\begin{tabular}{|l|c|c|}
\hline Input File Parameters & Parameter Values & \\
& 17 & \\
\hline
\end{tabular}




\begin{tabular}{|l|l|l|}
\hline (Note: Required are bolded) & (Note: Defaults are bolded) & \\
\hline [./name] & Unique name & Designates sub-block name \\
\hline type & Exodus & $\begin{array}{l}\text { Designates that the output file is in } \\
\text { the Exodus format }\end{array}$ \\
\hline execute_on & 'initial timestep_end' & $\begin{array}{l}\text { Control the execution of the output } \\
\text { file. Options are to set to } \\
\text { (none/initial|linear|nonlinear|time } \\
\text { step_end|timestep_begin|final|fai } \\
\text { led/custom) to execute only at that } \\
\text { moment }\end{array}$ \\
\hline show & $\begin{array}{l}\text { A list of the variables and } \\
\text { postprocessors that should be } \\
\text { output to the Exodus file (may } \\
\text { include Variables, ScalarVariables, } \\
\text { and Postprocessor names). }\end{array}$ \\
\hline sync_only & \begin{tabular}{l} 
Only export results at sync times \\
\hline sync_times
\end{tabular} & $\begin{array}{l}\text { Times at which the output and } \\
\text { solution is forced to occur }\end{array}$ \\
\hline use_displaced_mesh & $\begin{array}{l}\text { Specify 'true' to always use } \\
\text { displaced mesh }\end{array}$ \\
\hline
\end{tabular}

\subsection{Console}

The console output format is viewable on the computer screen.

\begin{tabular}{|l|l|l|}
\hline \multicolumn{1}{|c|}{ Input File Parameters } & \multicolumn{1}{|c|}{ Parameter Values } & \multicolumn{1}{c|}{ Description } \\
\hline [./name] & Unique name & Designates sub-block name \\
\hline type & console & $\begin{array}{l}\text { Designates that the output file is in } \\
\text { the format to be viewed on the } \\
\text { console }\end{array}$ \\
\hline execute_on & $\begin{array}{l}\text { 'initial timestep_end initial } \\
\text { timestep_begin linear } \\
\text { nonlinear failed' }\end{array}$ & $\begin{array}{l}\text { Control the execution of the output } \\
\text { file. Options are to set to } \\
\text { (none/initial|linear|nonlinear|time } \\
\text { step_end / timestep_begin|final|fai } \\
\text { led/custom) to execute only at that } \\
\text { moment }\end{array}$ \\
\hline outlier_variable_norms & $\begin{array}{l}\text { If true outlier variable norms will } \\
\text { be printed after each solve }\end{array}$ \\
\hline perf_log & $\begin{array}{l}\text { If true only export results at sync } \\
\text { times that execution and outputs }\end{array}$ \\
\hline
\end{tabular}




\begin{tabular}{|l|l|l|}
\hline show & & are forced to occur \\
\hline sync_only & $\begin{array}{l}\text { Times at which the output and } \\
\text { solution are forced to occur }\end{array}$ \\
\hline sync_times & Only export results at sync times \\
\hline
\end{tabular}




\subsection{POSTPROCESSORS}

The post-processor [Postprocessors] block specifies sub-blocks that calculate values that are used for run-time or post-processing applications.

Other post-processor options are included in RELAP-7 but are not specified here.

In the following sections the input file parameters for the [Postprocessors] sub-blocks are listed.

Post-processors that include the "boundary" parameter refers to [Inlet] and [Outlet] components and to two-dimensional [HeatStructure] components.

Vector post-processors exist in RELAP-7 for applications such as fluid temperatures along the length of a pipe. These are not specified here.

Commonly used post-processors are the [PointValue] that outputs the value of a parameter at a specific location $(x, y, z)$, the [ElementExtremeValue] that outputs a maximum or minimum value of a component parameter, and the [TimeStepSize] that outputs the time step size.

\subsection{Average Element Size}

The average element size postprocessor [AverageElementSize] sub-block computes an average element size (length) for the whole domain. If the component names (blocks) are specified, then the average length is for those components.

\begin{tabular}{|l|l|l|}
\hline \multicolumn{1}{|c|}{ Input File Parameters } & \multicolumn{1}{|c|}{ Parameter Values } & \multicolumn{1}{c|}{ Description } \\
\hline [./name] & (Note: Defaults are bolded) & $\begin{array}{l}\text { Designates sub-block component } \\
\text { name }\end{array}$ \\
\hline type & Unique name & $\begin{array}{l}\text { Designates an average element size } \\
\text { post-processor }\end{array}$ \\
\hline variable & (any value) & $\begin{array}{l}\text { This variable is not used here but is } \\
\text { currently required so use any value }\end{array}$ \\
\hline block & $\begin{array}{l}\text { The list of component names to be } \\
\text { included in the calculation. If none } \\
\text { are specified then all will be } \\
\text { included. }\end{array}$ \\
\hline execute_on & $\begin{array}{l}\text { Set to } \\
\text { (nonlinear /linear|timestep_end|tim } \\
\text { estep_begin / custom) to execute } \\
\text { only at that moment }\end{array}$ \\
\hline outputs & $\begin{array}{l}\text { The output names (i.e. console, csv, } \\
\text { exodus) for this post-processor. If } \\
\text { none provided then all specified in }\end{array}$ \\
\hline
\end{tabular}


[Outputs] will be used.

\subsection{Average Nodal Variable Value}

The average nodal variable value [AverageNodaIVariavbleValue] sub-block computes an average nodal value of a field variable (e.g. temperature in a pipe) for a component or components.

\begin{tabular}{|l|l|l|}
\hline \multicolumn{1}{|c|}{ Input File Parameters } & \multicolumn{1}{|c|}{ Parameter Values } & \multicolumn{1}{c|}{ Description } \\
\hline [./name] & (Note: Defaults are bolded) & $\begin{array}{l}\text { Designates sub-block component } \\
\text { name }\end{array}$ \\
\hline type & Unique name & $\begin{array}{l}\text { Designates an average nodal } \\
\text { variable value post-processor }\end{array}$ \\
\hline variable & & $\begin{array}{l}\text { The component parameter whose } \\
\text { value is to be averaged }\end{array}$ \\
\hline boundary & $\begin{array}{l}\text { The unique name(s) of a boundary } \\
\text { condition component(s) (e.g. } \\
\text { InletXX). }\end{array}$ \\
\hline execute_on & timestep_end & $\begin{array}{l}\text { Set to } \\
\text { (nonlinear /linear|timestep_end|ti } \\
\text { mestep_begin / custom) to execute } \\
\text { only at that moment }\end{array}$ \\
\hline outputs & $\begin{array}{l}\text { The output names (i.e. console, } \\
\text { csv, exodus) for this post- } \\
\text { processor. If none provided then } \\
\text { all specified in [Outputs] will be } \\
\text { used. }\end{array}$ \\
\hline
\end{tabular}

\subsection{Change Over Time Step}

The change over time step post-processor [ChangeOverTimeStepPostprocessor] sub-block computes the change in a post-processor value (new value minus old value), or the magnitude of its relative change (new value minus old value, divided by old value), over a time step or over the entire transient.

\begin{tabular}{|l|l|l|}
\hline \multicolumn{1}{|c|}{ Input File Parameters } & \multicolumn{1}{|c|}{ Parameter Values } & \multicolumn{1}{c|}{ Description } \\
\hline [./note: Required are bolded) & \multicolumn{1}{c|}{ (Note: Defaults are bolded) } & $\begin{array}{l}\text { Designates sub-block component } \\
\text { name }\end{array}$ \\
\hline type & Unique name & $\begin{array}{l}\text { ChangeOverTimeStepPostprotes a change over time step } \\
\text { cessor }\end{array}$ \\
\hline variable & (any value) & $\begin{array}{l}\text { This variable is not used but is } \\
\text { currently required so use any value }\end{array}$ \\
\hline postprocessor & $\begin{array}{l}\text { The name of the post-processor } \\
\text { output value input to this post- } \\
\text { processor }\end{array}$ \\
\hline
\end{tabular}




\begin{tabular}{|l|l|l|}
\hline $\begin{array}{l}\text { Change_with_respect_to__ } \\
\text { initial }\end{array}$ & true & $\begin{array}{l}\text { The default 'true' indicates that the } \\
\text { change is with respect to the time } \\
\text { zero value. 'False' indicates the } \\
\text { change if based on the value from } \\
\text { the previous time step. }\end{array}$ \\
\hline compute_relative_change & false & $\begin{array}{l}\text { The default 'false' indicates that } \\
\text { the change in the value will be } \\
\text { output. 'True' indicates that the } \\
\text { relative change in the value will be } \\
\text { output. }\end{array}$ \\
\hline execute_on & 'timestep_end' & $\begin{array}{l}\text { Control the execution of the output } \\
\text { file. Options are to set to } \\
\text { (none/initial |linear|nonlinear|time } \\
\text { step_end/timestep_begin|final|fail } \\
\text { ed/custom) to execute only at that } \\
\text { moment }\end{array}$ \\
\hline outputs & $\begin{array}{l}\text { The output names (i.e. console, csv, } \\
\text { exodus) for this post-processor. If } \\
\text { none provided then all specified in } \\
\text { [Outputs] will be used. }\end{array}$ \\
\hline
\end{tabular}

\subsection{Cumulative Value}

The cumulative value post-processor [CumulativeValuePostprocessor] sub-block computes a cumulative sum of a post-processor value over a transient.

\begin{tabular}{|l|l|l|}
\hline \multicolumn{1}{|c|}{ Input File Parameters } & \multicolumn{1}{|c|}{ Parameter Values } & \multicolumn{1}{c|}{ Description } \\
\hline [./note: Required are bolded) & (Note: Defaults are bolded) & $\begin{array}{l}\text { Designates sub-block component } \\
\text { name }\end{array}$ \\
\hline type & Unique name & $\begin{array}{l}\text { Designates a cumulative value post- } \\
\text { processor }\end{array}$ \\
\hline postprocessor & & $\begin{array}{l}\text { The name of the post-processor } \\
\text { value input to this post-processor }\end{array}$ \\
\hline execute_on & 'timestep_end' & $\begin{array}{l}\text { Control the execution of the output } \\
\text { file. Options are to set to } \\
\text { (none/initial|linear|nonlinear|time } \\
\text { step_end/timestep_begin|final|fail } \\
\text { ed/custom) to execute only at that } \\
\text { moment }\end{array}$ \\
\hline outputs & $\begin{array}{l}\text { The output names (i.e. console, csv, } \\
\text { exodus) for this post-processor. If } \\
\text { none provided then all specified in } \\
\text { [Outputs] will be used. }\end{array}$ \\
\hline
\end{tabular}




\subsection{Difference}

The difference post-processor [DifferencePostprocessor] sub-block computes the difference between two post-processors.

\begin{tabular}{|l|l|l|}
\hline \multicolumn{1}{|c|}{ Input File Parameters } & \multicolumn{1}{|c|}{ Parameter Values } & \multicolumn{1}{c|}{ Description } \\
\hline [./name] & Unique name & $\begin{array}{l}\text { Designates sub-block component } \\
\text { name }\end{array}$ \\
\hline Type & DifferencePostprocessor & $\begin{array}{l}\text { Designates a difference post- } \\
\text { processor }\end{array}$ \\
\hline value1 & $\begin{array}{l}\text { Name of the post-processor whose } \\
\text { output is the first value in the } \\
\text { difference calculation }\end{array}$ \\
\hline value2 & $\begin{array}{l}\text { Name of the post-processor whose } \\
\text { output is the second value in the } \\
\text { difference calculation }\end{array}$ \\
\hline execute_on & $\begin{array}{l}\text { Set to } \\
\text { (nonlinear /linear|timestep_end |ti } \\
\text { mestep_begin / custom) to execute } \\
\text { only at that moment }\end{array}$ \\
\hline outputs & timestep_end & $\begin{array}{l}\text { The output names (i.e. console, } \\
\text { csv, exodus) for this post- } \\
\text { processor. If none provided then } \\
\text { all specified in [Outputs] will be } \\
\text { used. }\end{array}$ \\
\hline
\end{tabular}

\subsection{Element Average Value}

The element average value post-processor [ElementAverageValue] sub-block computes the average value of a specified parameter for a component or components.

\begin{tabular}{|l|l|l|}
\hline \multicolumn{1}{|c|}{ Input File Parameters } & \multicolumn{1}{|c|}{ Parameter Values } & \multicolumn{1}{c|}{ Description } \\
(Note: Required are bolded) & (Note: Defaults are bolded) & $\begin{array}{l}\text { Designates sub-block component } \\
\text { name }\end{array}$ \\
\hline type & Unique name & $\begin{array}{l}\text { Designates an element average } \\
\text { value -processor }\end{array}$ \\
\hline variable & ElementAverageValue & $\begin{array}{l}\text { The component parameter whose } \\
\text { value is to be averaged }\end{array}$ \\
\hline block & & $\begin{array}{l}\text { The list of component names to be } \\
\text { included in the calculation. If none } \\
\text { are specified then all will be } \\
\text { included. }\end{array}$ \\
\hline execute_on & & Set to \\
\hline
\end{tabular}




\begin{tabular}{|l|l|l|}
\hline & & $\begin{array}{l}\text { (nonlinear|linear|timestep_end|ti } \\
\text { mestep_begin/custom) to execute } \\
\text { only at that moment }\end{array}$ \\
\hline outputs & $\begin{array}{l}\text { The output names (i.e. console, } \\
\text { csv, exodus) for this post- } \\
\text { processor. If none provided then } \\
\text { all specified in [Outputs] will be } \\
\text { used. }\end{array}$ \\
\hline
\end{tabular}

\subsection{Element Extreme Value}

The element extreme value post-processor [ElementExtremeValue] sub-block determines the extreme value (maximum or minimum) for a component parameter.

\begin{tabular}{|c|c|c|}
\hline $\begin{array}{c}\text { Input File Parameters } \\
\text { (Note: Required are bolded) }\end{array}$ & $\begin{array}{c}\text { Parameter Values } \\
\text { (Note: Defaults are bolded) }\end{array}$ & Description \\
\hline$[. /$ name $]$ & Unique name & $\begin{array}{l}\text { Designates sub-block component } \\
\text { name }\end{array}$ \\
\hline type & ElementAverageValue & $\begin{array}{l}\text { Designates an element extreme } \\
\text { value post-processor }\end{array}$ \\
\hline variable & & $\begin{array}{l}\text { The component parameter whose } \\
\text { extreme value is to be determined }\end{array}$ \\
\hline block & & $\begin{array}{l}\text { The list of component names to be } \\
\text { included in the calculation. If none } \\
\text { are specified then all will be } \\
\text { included. }\end{array}$ \\
\hline execute_on & timestep_end & $\begin{array}{l}\text { Set to } \\
\text { (nonlinear|linear|timestep_end |ti } \\
\text { mestep_begin |custom) to execute } \\
\text { only at that moment }\end{array}$ \\
\hline outputs & & $\begin{array}{l}\text { The output names (i.e. console, } \\
\text { csv, exodus) for this post- } \\
\text { processor. If none provided then } \\
\text { all specified in [Outputs] will be } \\
\text { used. }\end{array}$ \\
\hline value_type & $\max$ & $\begin{array}{l}\text { Type of extreme value to return. } \\
\text { 'max' returns the maximum value. } \\
\text { 'min' returns the minimum value. }\end{array}$ \\
\hline
\end{tabular}

\subsection{Element Heat Flux}

The element heat flux [ElementHeatFluxPostprocessor] post-processor sub-block computes the integrated heat flux (positive value indicates into the heat structure) across a heat structure [HeatStructure] component.

\begin{tabular}{|c|c|c|}
\hline Input File Parameters & Parameter Values & Description \\
\hline
\end{tabular}




\begin{tabular}{|c|c|c|}
\hline (Note: Required are bolded) & (Note: Defaults are bolded) & \\
\hline$[. /$ name $]$ & Unique name & $\begin{array}{l}\text { Designates sub-block component } \\
\text { name }\end{array}$ \\
\hline type & $\begin{array}{l}\text { ElementHeatFluxPostprocess } \\
\text { or }\end{array}$ & $\begin{array}{l}\text { Designates an element heat flux } \\
\text { post-processor }\end{array}$ \\
\hline Hw & & Heat transfer coefficient of the wall \\
\hline P_hf & & Heat flux perimeter \\
\hline T_wall & & Temperature of the wall \\
\hline T_fluid & & Temperature of the fluid \\
\hline block & & $\begin{array}{l}\text { The list of heat structure names to } \\
\text { be included in the calculation. If } \\
\text { none are specified then all will be } \\
\text { included. }\end{array}$ \\
\hline execute_on & timestep_end & $\begin{array}{l}\text { Set to } \\
\text { (nonlinear|linear|timestep_end } \mid \text { ti } \\
\text { mestep_begin |custom) to execute } \\
\text { only at that moment }\end{array}$ \\
\hline outputs & & $\begin{array}{l}\text { The output names (i.e. console, } \\
\text { csv, exodus) for this post- } \\
\text { processor. If none provided then } \\
\text { all specified in [Outputs] will be } \\
\text { used. }\end{array}$ \\
\hline
\end{tabular}

\subsection{Extreme Value Over Time}

The extreme value over time post-processor [TimeExtremeValue] reports the maximum or minimum value, or the absolute value of the maximum or minimum value, of the output value of another postprocessor.

\begin{tabular}{|l|l|l|}
\hline \multicolumn{1}{|c|}{ Input File Parameters } & \multicolumn{1}{|c|}{ Parameter Values } & \multicolumn{1}{c|}{ Description } \\
\hline [./note: Required are bolded) & \multicolumn{1}{c|}{ (Note: Defaults are bolded) } & $\begin{array}{l}\text { Designates sub-block component } \\
\text { name }\end{array}$ \\
\hline type & Unique name & $\begin{array}{l}\text { Designates a extreme value post- } \\
\text { processor }\end{array}$ \\
\hline postprocessor & TimeExtremeValue & $\begin{array}{l}\text { The name of the postprocessor } \\
\text { whose output value is evaluated } \\
\text { for extreme values }\end{array}$ \\
\hline execute_on & $\begin{array}{l}\text { Set to } \\
\text { (nonlinear } \mid \text { linear|timestep_end|ti }\end{array}$ \\
\hline
\end{tabular}




\begin{tabular}{|l|l|l|}
\hline & & $\begin{array}{l}\text { mestep_begin (custom) to execute } \\
\text { only at that moment }\end{array}$ \\
\hline outputs & $\begin{array}{l}\text { The output names (i.e. console, } \\
\text { csv, exodus) for this post- } \\
\text { processor. If none provided then } \\
\text { all specified in [Outputs] will be } \\
\text { used. }\end{array}$ \\
\hline value_type & max & $\begin{array}{l}\text { Type of extreme value to return: } \\
\text { 'max returns the maximum value; } \\
\text { 'min' returns the minimum value; } \\
\text { 'abs_max' returns the maximum } \\
\text { absolute value; 'abs_min' returns } \\
\text { the minimum absolute value. }\end{array}$ \\
\hline
\end{tabular}

\subsection{Function Value}

The function value post-processor [FunctionValuePostprocessor] sub-block specifies the function that provides the value to be used in another post-processor. A typical use would be a function that samples a parameter value in time at a specified point in space. The point in space is specified by this postprocessor.

\begin{tabular}{|l|l|l|}
\hline \multicolumn{1}{|c|}{ Input File Parameters } & \multicolumn{1}{|c|}{ Parameter Values } & \multicolumn{1}{c|}{ Description } \\
\hline [./name] & (Note: Defaults are bolded) & $\begin{array}{l}\text { Designates sub-block component } \\
\text { name }\end{array}$ \\
\hline type & Unique name & $\begin{array}{l}\text { Designates a function value post- } \\
\text { processor }\end{array}$ \\
\hline function & $\begin{array}{l}\text { The name of the function that } \\
\text { supplies the input value to this } \\
\text { postprocessor }\end{array}$ \\
\hline execute_on & timestep_end & $\begin{array}{l}\text { Set to } \\
\text { (nonlinear /linear|timestep_end|ti } \\
\text { mestep_begin / custom) to execute } \\
\text { only at that moment }\end{array}$ \\
\hline outputs & $\begin{array}{l}\text { The output names (i.e. console, } \\
\text { csv, exodus) for this post- } \\
\text { processor. If none provided then } \\
\text { all specified in [Outputs] will be } \\
\text { used. }\end{array}$ \\
\hline point & $\begin{array}{l}\text { A point in space (x,y,z) to be given } \\
\text { to the function }\end{array}$ \\
\hline use_displaced_mesh & $\begin{array}{l}\text { Specify 'true' to always use } \\
\text { displaced mesh }\end{array}$ \\
\hline & '0 0 0' & false \\
& & \\
\hline
\end{tabular}




\subsection{Linear Combination}

The linear combination post-processor [LinearCombinationPostprocessor] sub-block calculates the sum of pairs of post-processor output values (input to this post-processor) multiplied by coefficients (parameter values specified in this postprocessor), plus a constant value (specified in this postprocessor).

\begin{tabular}{|c|c|c|}
\hline $\begin{array}{l}\text { Input File Parameters } \\
\text { (Note: Required are bolded) }\end{array}$ & $\begin{array}{c}\text { Parameter Values } \\
\text { (Note: Defaults are bolded) }\end{array}$ & Description \\
\hline$[. /$ name $]$ & Unique name & $\begin{array}{l}\text { Designates sub-block component } \\
\text { name }\end{array}$ \\
\hline type & $\begin{array}{l}\text { LinearCombinationPostproce } \\
\text { ssor }\end{array}$ & $\begin{array}{l}\text { Designates a linear combination } \\
\text { post-processor }\end{array}$ \\
\hline pp_coefs & & $\begin{array}{l}\text { List of coefficients to be multiplied } \\
\text { by post-processor values listed in } \\
\text { the 'pp_names' parameter. These } \\
\text { are paired values. }\end{array}$ \\
\hline pp_names & & $\begin{array}{l}\text { List of post-processor names } \\
\text { whose values are multiplied by the } \\
\text { list of coefficients in the 'pp_coefs' } \\
\text { parameter. These are paired } \\
\text { values. }\end{array}$ \\
\hline $\mathrm{b}$ & 0 & $\begin{array}{l}\text { A constant value to be add to the } \\
\text { sum of pairs of multiplied values. }\end{array}$ \\
\hline execute_on & timestep_end & $\begin{array}{l}\text { Set to } \\
\text { (nonlinear|linear|timestep_end } \mid \text { ti } \\
\text { mestep_begin |custom) to execute } \\
\text { only at that moment }\end{array}$ \\
\hline outputs & & $\begin{array}{l}\text { The output names (i.e. console, } \\
\text { csv, exodus) for this post- } \\
\text { processor. If none provided then } \\
\text { all specified in [Outputs] will be } \\
\text { used. }\end{array}$ \\
\hline
\end{tabular}

\subsection{Mass Flux Integral}

The mass flux integral post-processor [MassFluxIntegral] sub-block calculates the integrated mass flux (total mass) across a boundary condition component (e.g. [Inlet]).

\begin{tabular}{|l|l|l|}
\hline \multicolumn{1}{|c|}{ Input File Parameters } & \multicolumn{1}{|c|}{ Parameter Values } & \multicolumn{1}{c|}{ Description } \\
(Note: Required are bolded) & (Note: Defaults are bolded) & \\
\hline [./name] & Unique name & $\begin{array}{l}\text { Designates sub-block component } \\
\text { name }\end{array}$ \\
\hline type & MassFluxIntegral & $\begin{array}{l}\text { Designates a mass flux integral post- } \\
\text { processor }\end{array}$ \\
\hline
\end{tabular}




\begin{tabular}{|l|l|l|}
\hline arhouA & & $\begin{array}{l}\text { Product of void fraction * density } \\
\text { *velocity*area }\end{array}$ \\
\hline boundary & $\begin{array}{l}\text { The unique name(s) of a boundary } \\
\text { condition component(s) (e.g. } \\
\text { InletXX). }\end{array}$ \\
\hline execute_on & $\begin{array}{l}\text { Set to } \\
\text { (nonlinear /linear|timestep_end/ti } \\
\text { mestep_begin / custom) to execute } \\
\text { only at that moment }\end{array}$ \\
\hline outputs & $\begin{array}{l}\text { The output names (i.e. console, } \\
\text { csv, exodus) for this post- } \\
\text { processor. If none provided then } \\
\text { all specified in [Outputs] will be } \\
\text { used. }\end{array}$ \\
\hline
\end{tabular}

\subsection{Momentum Flux Integral}

The momentum flux integral post-processor [MomentumfluxIntegral] sub-block calculates the integral of the momentum flux across a boundary component, such as an [Outlet].

\begin{tabular}{|c|c|c|}
\hline $\begin{array}{l}\text { Input File Parameters } \\
\text { (Note: Required are bolded) }\end{array}$ & $\begin{array}{c}\text { Parameter Values } \\
\text { (Note: Defaults are bolded) }\end{array}$ & Description \\
\hline$[. /$ name $]$ & Unique name & $\begin{array}{l}\text { Designates sub-block component } \\
\text { name }\end{array}$ \\
\hline type & MomentumFluxIntegral & $\begin{array}{l}\text { Designates a momentum flux } \\
\text { integral post-processor }\end{array}$ \\
\hline A & & Area \\
\hline arhouA & & $\begin{array}{l}\text { Product of void fraction * density } \\
\text { *velocity*area }\end{array}$ \\
\hline boundary & & $\begin{array}{l}\text { The unique name(s) of a boundary } \\
\text { condition component(s) (e.g. } \\
\text { OutletXX). }\end{array}$ \\
\hline $\mathbf{p}$ & & Pressure \\
\hline vel & & Velocity \\
\hline alpha & 1.0 & Volume fraction (two-phase only) \\
\hline execute_on & timestep_end & $\begin{array}{l}\text { Set to } \\
\text { (nonlinear|linear|timestep_end|ti } \\
\text { mestep_begin |custom) to execute } \\
\text { only at that moment }\end{array}$ \\
\hline outputs & & $\begin{array}{l}\text { The output names (i.e. console, } \\
\text { csv, exodus) for this post- }\end{array}$ \\
\hline
\end{tabular}




\begin{tabular}{|l|l|l|}
\hline & $\begin{array}{l}\text { processor. If none provided then } \\
\text { all specified in [Outputs] will be } \\
\text { used. }\end{array}$ \\
\hline
\end{tabular}

\subsection{Nodal Energy Flux}

The nodal energy flux post-processor [NodalEnergyFluxPostprocessor] sub-block calculates the energy flux across a boundary component, such as an [Outlet].

\begin{tabular}{|c|c|c|}
\hline $\begin{array}{l}\text { Input File Parameters } \\
\text { (Note: Required are bolded) }\end{array}$ & $\begin{array}{c}\text { Parameter Values } \\
\text { (Note: Defaults are bolded) }\end{array}$ & Description \\
\hline$[. /$ name $]$ & Unique name & $\begin{array}{l}\text { Designates sub-block component } \\
\text { name }\end{array}$ \\
\hline type & $\begin{array}{l}\text { NodalEnergyFluxPostprocess } \\
\text { or }\end{array}$ & $\begin{array}{l}\text { Designates a nodal energy flux } \\
\text { post-processor }\end{array}$ \\
\hline $\mathbf{H}$ & & $\begin{array}{l}\text { Specific total enthalpy is the sum of } \\
\text { the specific enthalpy and the } \\
\text { specific kinetic energy. }\end{array}$ \\
\hline arhouA & & $\begin{array}{l}\text { Alpha(liquid void } \\
\text { fraction)*rho*u*A }\end{array}$ \\
\hline boundary & & $\begin{array}{l}\text { The unique name(s) of a boundary } \\
\text { condition component(s) (e.g. } \\
\text { OutletXX). }\end{array}$ \\
\hline execute_on & timestep_end & $\begin{array}{l}\text { Set to } \\
\text { (nonlinear|linear|timestep_end } \mid \text { ti } \\
\text { mestep_begin } \mid \text { custom) to execute } \\
\text { only at that moment }\end{array}$ \\
\hline outputs & & $\begin{array}{l}\text { The output names (i.e. console, } \\
\text { csv, exodus) for this post- } \\
\text { processor. If none provided then } \\
\text { all specified in [Outputs] will be } \\
\text { used. }\end{array}$ \\
\hline
\end{tabular}

\subsection{Nodal Extreme Value}

The nodal extreme value post-processor [NodalExtremeValue] sub-block determines the extreme value (maximum or minimum) for a boundary component (e.g. [Outlet]) parameter.

\begin{tabular}{|l|l|l|}
\hline \multicolumn{1}{|c|}{ Input File Parameters } & \multicolumn{1}{|c|}{ Parameter Values } & \multicolumn{1}{c|}{ Description } \\
(Note: Required are bolded) & (Note: Defaults are bolded) & $\begin{array}{l}\text { Designates sub-block component } \\
\text { name }\end{array}$ \\
\hline [./name] & Unique name & $\begin{array}{l}\text { Designates a nodal extreme value } \\
\text { post-processor }\end{array}$ \\
\hline type & NodalExtremeValue & The component parameter whose \\
\hline variable & & \\
\hline
\end{tabular}




\begin{tabular}{|l|l|l|}
\hline boundary & & extreme value is to be determined \\
\hline execute_on & $\begin{array}{l}\text { The unique name(s) of a boundary } \\
\text { condition component(s) (e.g. } \\
\text { OutletXX). }\end{array}$ \\
\hline outputs & timestep_end & $\begin{array}{l}\text { Set to } \\
\text { (nonlinear/linear|timestep_end|ti } \\
\text { mestep_begin /custom) to execute } \\
\text { only at that moment }\end{array}$ \\
\hline value_type & $\begin{array}{l}\text { The output names (i.e. console, } \\
\text { csv, exodus) for this post- } \\
\text { processor. If none provided then } \\
\text { all specified in [Outputs] will be } \\
\text { used. }\end{array}$ \\
\hline & max & $\begin{array}{l}\text { Type of extreme value to return: } \\
\text { 'max' returns the maximum value. } \\
\text { 'min' returns the minimum value. }\end{array}$ \\
\hline
\end{tabular}

\subsection{Nodal Sum}

The nodal sum value post-processor [NodalSum] sub-block sums the values of a parameter for all of the nodes in a component at each time step. An example would be summing nodal mass values to obtain a total mass output for this post-processor.

\begin{tabular}{|l|l|l|}
\hline \multicolumn{1}{|c|}{ Input File Parameters } & \multicolumn{1}{|c|}{ Parameter Values } & \multicolumn{1}{c|}{ Description } \\
\hline [./name] & (Note: Defaults are bolded) & $\begin{array}{l}\text { Designates sub-block component } \\
\text { name }\end{array}$ \\
\hline Type & Unique name & $\begin{array}{l}\text { Designates a nodal sum post- } \\
\text { processor }\end{array}$ \\
\hline variable & NodalSum & $\begin{array}{l}\text { The component parameter value } \\
\text { that will be summed. }\end{array}$ \\
\hline block & $\begin{array}{l}\text { The component containing the } \\
\text { nodes for which the parameter } \\
\text { values will be summed each time } \\
\text { step. }\end{array}$ \\
\hline execute_on & $\begin{array}{l}\text { Set to } \\
\text { (nonlinear /linear|timestep_end|ti } \\
\text { mestep_begin / custom) to execute } \\
\text { only at that moment }\end{array}$ \\
\hline outputs & $\begin{array}{l}\text { The output names (i.e. console, } \\
\text { csv, exodus) for this post- } \\
\text { processor. If none provided then } \\
\text { all specified in [Outputs] will be } \\
\text { used. }\end{array}$ \\
\hline
\end{tabular}




\subsection{Number of Elements}

The number of elements post-processor [NumElems] sub-block provides the total number of elements in the simulation model.

\begin{tabular}{|l|l|l|}
\hline \multicolumn{1}{|c|}{ Input File Parameters } & \multicolumn{1}{|c|}{ Parameter Values } & \multicolumn{1}{c|}{ Description } \\
\hline [Note: Required are bolded) & (Note: Defaults are bolded) & $\begin{array}{l}\text { Designates sub-block component } \\
\text { name }\end{array}$ \\
\hline type & Unique name & $\begin{array}{l}\text { Designates a number of elements } \\
\text { post-processor }\end{array}$ \\
\hline elem_filter & NumElems & $\begin{array}{l}\text { Specifies that only active elements } \\
\text { (those are used in the simulation } \\
\text { model) are counted }\end{array}$ \\
\hline execute_on & active & $\begin{array}{l}\text { Set to } \\
\text { (nonlinear /linear/timestep_end|ti } \\
\text { mestep_begin / custom) to execute } \\
\text { only at that moment }\end{array}$ \\
\hline outputs & timestep_end & $\begin{array}{l}\text { The output names (i.e. console, } \\
\text { csv, exodus) for this post- } \\
\text { processor. If none provided then } \\
\text { all specified in [Outputs] will be } \\
\text { used. }\end{array}$ \\
\hline
\end{tabular}

\subsection{Number of Linear Iterations}

The number of linear iterations post-processor [NumLinearlterations] sub-block outputs the number of linear iterations at each time step.

\begin{tabular}{|l|l|l|}
\hline \multicolumn{1}{|c|}{ Input File Parameters } & \multicolumn{1}{|c|}{ Parameter Values } & \multicolumn{1}{c|}{ Description } \\
\hline [Note: Required are bolded) & (Note: Defaults are bolded) & $\begin{array}{l}\text { Designates sub-block component } \\
\text { name }\end{array}$ \\
\hline type & Unique name & $\begin{array}{l}\text { Designates a number of linear } \\
\text { iterations post-processor }\end{array}$ \\
\hline execute_on & NumLinearlterations & $\begin{array}{l}\text { Set to } \\
\text { (nonlinear /linear|timestep_end|ti } \\
\text { mestep_begin / custom) to execute } \\
\text { only at that moment }\end{array}$ \\
\hline outputs & timestep_end & $\begin{array}{l}\text { The output names (i.e. console, } \\
\text { csv, exodus) for this post- } \\
\text { processor. If none provided then } \\
\text { all specified in [Outputs] will be } \\
\text { used. }\end{array}$ \\
\hline
\end{tabular}




\subsection{Number of Nodes}

The number of nodes post-processor [NumNodes] sub-block outputs the number of nodes.

\begin{tabular}{|l|l|l|}
\hline \multicolumn{1}{|c|}{ Input } & \multicolumn{1}{|c|}{ Parameter Values } & \multicolumn{1}{c|}{ Description } \\
\hline [./note: Required are bolded) & (Note: Defaults are bolded) & $\begin{array}{l}\text { Designates sub-block component } \\
\text { name }\end{array}$ \\
\hline type & Unique name & $\begin{array}{l}\text { Designates a number of nodes post- } \\
\text { processor }\end{array}$ \\
\hline execute_on & NumNodes & $\begin{array}{l}\text { Set to } \\
\text { (nonlinear /linear|timestep_end|ti } \\
\text { mestep_begin/custom) to execute } \\
\text { only at that moment }\end{array}$ \\
\hline outputs & timestep_end & $\begin{array}{l}\text { The output names (i.e. console, } \\
\text { csv, exodus) for this post- } \\
\text { processor. If none provided then } \\
\text { all specified in [Outputs] will be } \\
\text { used. }\end{array}$ \\
\hline
\end{tabular}

\subsection{Number of Non-Linear Iterations}

The number of non-linear iterations post-processor [NumNonlinearlterations] sub-block outputs the number of non-linear iterations at each time step.

\begin{tabular}{|l|l|l|}
\hline \multicolumn{1}{|c|}{ Input File Parameters } & \multicolumn{1}{|c|}{ Parameter Values } & \multicolumn{1}{c|}{ Description } \\
\hline [Note: Required are bolded) & (Note: Defaults are bolded) & $\begin{array}{l}\text { Designates sub-block component } \\
\text { name }\end{array}$ \\
\hline type & Unique name & $\begin{array}{l}\text { Designates a number non-lonear } \\
\text { iterations post-processor }\end{array}$ \\
\hline accumulate_over_step & false & $\begin{array}{l}\text { Specify 'true' to count the number } \\
\text { of non-linear iterations for each } \\
\text { time step }\end{array}$ \\
\hline execute_on & true & $\begin{array}{l}\text { Set to } \\
\text { (nonlinear /linear|timestep_end|ti } \\
\text { mestep_begin / custom) to execute } \\
\text { only at that moment }\end{array}$ \\
\hline outputs & $\begin{array}{l}\text { The output names (i.e. console, } \\
\text { csv, exodus) for this post- } \\
\text { processor. If none provided then } \\
\text { all specified in [Outputs] will be } \\
\text { used. }\end{array}$ \\
\hline
\end{tabular}




\subsection{Number of Residual Evaluations}

The number of residual evaluations post-processor [NumResidualEvaluations] sub-block outputs the number of residual evaluations at each time step.

\begin{tabular}{|l|l|l|}
\hline \multicolumn{1}{|c|}{ Input File Parameters } & \multicolumn{1}{|c|}{ Parameter Values } & \multicolumn{1}{c|}{ Description } \\
\hline [./note: Required are bolded) & (Note: Defaults are bolded) & $\begin{array}{l}\text { Designates sub-block component } \\
\text { name }\end{array}$ \\
\hline type & Unique name & $\begin{array}{l}\text { Designates a number of residual } \\
\text { evalations post-processor }\end{array}$ \\
\hline execute_on & NumResidualEvaluations & $\begin{array}{l}\text { Set to } \\
\text { (nonlinear |linear|timestep_end|ti } \\
\text { mestep_begin / custom) to execute } \\
\text { only at that moment }\end{array}$ \\
\hline outputs & $\begin{array}{l}\text { The output names (i.e. console, } \\
\text { csv, exodus) for this post- } \\
\text { processor. If none provided then } \\
\text { all specified in [Outputs] will be } \\
\text { used. }\end{array}$ \\
\hline
\end{tabular}

\subsection{Point Value}

The point value post-processor [PointValue] sub-block outputs the value of a parameter (e.g. temperature) at a specific location $(x, y, z)$ in the displaced mesh.

\begin{tabular}{|l|l|l|}
\hline \multicolumn{1}{|c|}{ Input File Parameters } & \multicolumn{1}{|c|}{ Parameter Values } & \multicolumn{1}{c|}{ Description } \\
\hline [./name] & (Note: Defaults are bolded) & $\begin{array}{l}\text { Designates sub-block component } \\
\text { name }\end{array}$ \\
\hline type & Unique name & $\begin{array}{l}\text { Designates a point value post- } \\
\text { processor }\end{array}$ \\
\hline point & '0 0 0' & $\begin{array}{l}\text { The physical point where the } \\
\text { solution will be evaluated.('x y z') }\end{array}$ \\
\hline variable & timestep_end & $\begin{array}{l}\text { The parameter name (e.g. 'T', ' } p \text { ' } \\
\text { whose value is to be output. }\end{array}$ \\
\hline execute_on & $\begin{array}{l}\text { Set to } \\
\text { (nonlinear } / \text { linear|timestep_end|ti } \\
\text { mestep_begin |custom) [initial time } \\
\text { step_end] to execute only at that } \\
\text { moment }\end{array}$ \\
\hline outputs & $\begin{array}{l}\text { The output names (i.e. console, } \\
\text { csv, exodus) for this post- } \\
\text { processor. If none provided then } \\
\text { all specified in [Outputs] will be }\end{array}$ \\
\hline
\end{tabular}




\begin{tabular}{|l|l|l|}
\hline & & used. \\
\hline use_displaced_mesh & $\begin{array}{l}\text { false } \\
\text { true }\end{array}$ & $\begin{array}{l}\text { Specify 'true' to always use } \\
\text { displaced mesh }\end{array}$ \\
\hline
\end{tabular}

\subsection{Real Component Parameter Value}

The real component parameter value postprocessor [RealComponentParameterValuePostprocessor] subblock outputs the numerical value of a component parameter.

\begin{tabular}{|l|l|l|}
\hline \multicolumn{1}{|c|}{ Input File Parameters } & \multicolumn{1}{|c|}{ Parameter Values } & \multicolumn{1}{|c|}{ Description } \\
\hline [./name] & (Note: Defaults are bolded) & $\begin{array}{l}\text { Designates sub-block component } \\
\text { name }\end{array}$ \\
\hline type & Unique name & $\begin{array}{l}\text { RealComponentParameterVa } \\
\text { luePostprocessor } \\
\text { parameter value post-processor }\end{array}$ \\
\hline component & timestep_end & $\begin{array}{l}\text { The name of the component whose } \\
\text { parameter value is output. }\end{array}$ \\
\hline parameter & $\begin{array}{l}\text { The name of the component } \\
\text { parameter whose numerical value } \\
\text { is output }\end{array}$ \\
\hline execute_on & $\begin{array}{l}\text { Set to } \\
\text { (nonlinear } \text { |linear|timestep_end|ti } \\
\text { mestep_begin / custom) to execute } \\
\text { only at that moment }\end{array}$ \\
\hline outputs & $\begin{array}{l}\text { The output names (i.e. console, } \\
\text { csv, exodus) for this post- } \\
\text { processor. If none provided then } \\
\text { all specified in [Outputs] will be } \\
\text { used. }\end{array}$ \\
\hline
\end{tabular}

\subsection{Real Control Data Value}

The real control data value postprocessor [RealContolDataValuePostprocessor] sub-block outputs the numerical value of a control.

\begin{tabular}{|l|l|l|}
\hline \multicolumn{1}{|c|}{ Input File Parameters } & \multicolumn{1}{|c|}{ Parameter Values } & \multicolumn{1}{c|}{ Description } \\
(Note: Required are bolded) & \multicolumn{1}{c|}{ (Note: Defaults are bolded) } & \\
\hline [./name] & Unique name & $\begin{array}{l}\text { Designates sub-block component } \\
\text { name }\end{array}$ \\
\hline type & $\begin{array}{l}\text { RealControlDataValuePostpr } \\
\text { ocessor }\end{array}$ & $\begin{array}{l}\text { Designates a real control data value } \\
\text { post-processor }\end{array}$ \\
\hline control_data_name & & $\begin{array}{l}\text { The name of the control whose } \\
\text { numerical value is output. }\end{array}$ \\
\hline execute_on & timestep_end & Set to \\
\hline
\end{tabular}




\begin{tabular}{|l|l|l|}
\hline & & $\begin{array}{l}\text { (nonlinear|linear|timestep_end|ti } \\
\text { mestep_begin/custom) to execute } \\
\text { only at that moment }\end{array}$ \\
\hline outputs & $\begin{array}{l}\text { The output names (i.e. console, } \\
\text { csv, exodus) for this post- } \\
\text { processor. If none provided then } \\
\text { all specified in [Outputs] will be } \\
\text { used. }\end{array}$ \\
\hline
\end{tabular}

\subsection{Relative Difference}

The relative difference post-processor [RelativeDifferencePostprocessor] sub-block computes the absolute value of the relative difference between two post-processor values.

\begin{tabular}{|l|l|l|}
\hline \multicolumn{1}{|c|}{ Input File Parameters } & \multicolumn{1}{|c|}{ Parameter Values } & \multicolumn{1}{c|}{ Description } \\
\hline [./name] & (Note: Defaults are bolded) & $\begin{array}{l}\text { Designates sub-block component } \\
\text { name }\end{array}$ \\
\hline type & $\begin{array}{l}\text { RelativeDifferencePostproces } \\
\text { sor }\end{array}$ & $\begin{array}{l}\text { Designates a difference post- } \\
\text { processor }\end{array}$ \\
\hline value1 & & $\begin{array}{l}\text { First post-processor that provides a } \\
\text { value }\end{array}$ \\
\hline value2 & $\begin{array}{l}\text { Second post-processor that } \\
\text { provides a value to be used as the } \\
\text { base for relative difference } \\
\text { compared to the first value }\end{array}$ \\
\hline execute_on & timestep_end & $\begin{array}{l}\text { Set to } \\
\text { (nonlinear /linear|timestep_end|ti } \\
\text { mestep_begin / custom) to execute } \\
\text { only at that moment }\end{array}$ \\
\hline outputs & $\begin{array}{l}\text { The output names (i.e. console, } \\
\text { csv, exodus) for this post- } \\
\text { processor. If none provided then } \\
\text { all specified in [Outputs] will be } \\
\text { used. }\end{array}$ \\
\hline
\end{tabular}

\subsection{Scalar Variable}

The scalar variable post-processor [ScalarVariable] sub-block outputs a scalar variable value for a specified component.

\begin{tabular}{|c|l|l|}
\hline \multicolumn{1}{|c|}{ Input File Parameters } & \multicolumn{1}{|c|}{ Parameter Values } & \multicolumn{1}{c|}{ Description } \\
(Note: Required are bolded) & (Note: Defaults are bolded) & \\
\hline [./name] & Unique name & $\begin{array}{l}\text { Designates sub-block component } \\
\text { name }\end{array}$ \\
\hline
\end{tabular}




\begin{tabular}{|l|l|l|}
\hline type & ScalarVariable & $\begin{array}{l}\text { Designates a scalar variable post- } \\
\text { processor }\end{array}$ \\
\hline variable & $\mathbf{0}$ & $\begin{array}{l}\text { Name of the component scalar } \\
\text { parameter }\end{array}$ \\
\hline component & timestep_end & $\begin{array}{l}\text { Component whose scalar variable } \\
\text { is output }\end{array}$ \\
\hline execute_on & $\begin{array}{l}\text { Set to } \\
\text { (nonlinear /linear|timestep_end|ti } \\
\text { mestep_begin / custom) to execute } \\
\text { only at that moment }\end{array}$ \\
\hline outputs & $\begin{array}{l}\text { The output names (i.e. console, } \\
\text { csv, exodus) for this post- } \\
\text { processor. If none provided then } \\
\text { all specified in [Outputs] will be } \\
\text { used. }\end{array}$ \\
\hline
\end{tabular}

\subsection{Scaling Factor}

The scaling factor post-processor [ScalePostprocessor] multiplies a post-processor value by a specified scaling factor.

\begin{tabular}{|l|l|l|}
\hline \multicolumn{1}{|c|}{ Input File Parameters } & \multicolumn{1}{|c|}{ Parameter Values } & \multicolumn{1}{c|}{ Description } \\
\hline [./name] & (Note: Defaults are bolded) & $\begin{array}{l}\text { Designates sub-block component } \\
\text { name }\end{array}$ \\
\hline type & Unique name & Designates a scaling post-processor \\
\hline value & ScalePostprocessor & $\begin{array}{l}\text { The post-processor whose output } \\
\text { value is to be multiplied by the } \\
\text { scaling factor }\end{array}$ \\
\hline execute_on & timestep_end & $\begin{array}{l}\text { Set to } \\
\text { (nonlinear } / \text { linear|timestep_end|ti } \\
\text { mestep_begin / custom) to execute } \\
\text { only at that moment }\end{array}$ \\
\hline outputs & $\begin{array}{l}\text { The output names (i.e. console, } \\
\text { csv, exodus) for this post- } \\
\text { processor. If none provided then } \\
\text { all specified in [Outputs] will be } \\
\text { used. }\end{array}$ \\
\hline scaling_factor & $\begin{array}{l}\text { The scaling factor that is used as a } \\
\text { multiplier applied to the post- } \\
\text { processor value }\end{array}$ \\
\hline
\end{tabular}

\subsection{Side Average Value}

The side average value post-processor [SideAverageValue] computes the average value of a parameter 
for a heat structure [HeatStructure] surface.

\begin{tabular}{|l|l|l|}
\hline \multicolumn{1}{|c|}{ Input File Parameters } & \multicolumn{1}{|c|}{ Parameter Values } & \multicolumn{1}{c|}{ Description } \\
\hline [./note: Required are bolded) & (Note: Defaults are bolded) & $\begin{array}{l}\text { Designates sub-block component } \\
\text { name }\end{array}$ \\
\hline type & Unique name & $\begin{array}{l}\text { Designates a side average value } \\
\text { post-processor }\end{array}$ \\
\hline boundary & SideAverageValue & $\begin{array}{l}\text { The name of the heat structure } \\
\text { component }\end{array}$ \\
\hline variable & & $\begin{array}{l}\text { The name of the parameter to be } \\
\text { averaged (e.g. T_surface) }\end{array}$ \\
\hline execute_on & $\begin{array}{l}\text { Set to } \\
\text { (nonlinear /linear|timestep_end|ti } \\
\text { mestep_begin / custom) to execute } \\
\text { only at that moment }\end{array}$ \\
\hline outputs & timestep_end & $\begin{array}{l}\text { The output names (i.e. console, } \\
\text { csv, exodus) for this post- } \\
\text { processor. If none provided then } \\
\text { all specified in [Outputs] will be } \\
\text { used. }\end{array}$ \\
\hline
\end{tabular}

\subsection{Side Flux Average}

The side average flux post-processor [SideFluxAverage] computes the average of the flux for a heat structure [HeatStructure] surface.

\begin{tabular}{|l|l|l|}
\hline \multicolumn{1}{|c|}{ Input File Parameters } & \multicolumn{1}{|c|}{ Parameter Values } & \multicolumn{1}{c|}{ Description } \\
\hline [./note: Required are bolded) & (Note: Defaults are bolded) & $\begin{array}{l}\text { Designates sub-block component } \\
\text { name }\end{array}$ \\
\hline type & Unique name & $\begin{array}{l}\text { Designates a side average flux post- } \\
\text { processor }\end{array}$ \\
\hline boundary & SideFluxAverage & $\begin{array}{l}\text { The name of the heat structure } \\
\text { component }\end{array}$ \\
\hline diffusivity & $\begin{array}{l}\text { The name of the diffusivity material } \\
\text { property that will be used in the } \\
\text { flux computation. }\end{array}$ \\
\hline variable & $\begin{array}{l}\text { The name of the flux parameter } \\
\text { (e.g. heat flux) to be averaged }\end{array}$ \\
\hline execute_on & $\begin{array}{l}\text { Set to } \\
\text { (nonlinear } / \text { linear|timestep_end|ti } \\
\text { mestep_begin |custom) to execute } \\
\text { only at that moment }\end{array}$ \\
\hline outputs & timestep_end & The output names (i.e. console, \\
\hline
\end{tabular}




\begin{tabular}{|l|l|l|}
\hline & $\begin{array}{l}\text { csv, exodus) for this post- } \\
\text { processor. If none provided then } \\
\text { all specified in [Outputs] will be } \\
\text { used. }\end{array}$ \\
\hline
\end{tabular}

\subsection{Side Flux Integral}

The side flux integral post-processor [SideFluxIntegral] computes the integral of the flux for a heat structure [HeatStructure] surface.

\begin{tabular}{|l|l|l|}
\hline \multicolumn{1}{|c|}{ Input File Parameters } & \multicolumn{1}{|c|}{ Parameter Values } & \multicolumn{1}{|c|}{ Description } \\
\hline [Note: Required are bolded) & (Note: Defaults are bolded) & $\begin{array}{l}\text { Designates sub-block component } \\
\text { name }\end{array}$ \\
\hline type & Unique name & $\begin{array}{l}\text { Designates a side flux integral post- } \\
\text { processor }\end{array}$ \\
\hline boundary & SideFluxIntegral & $\begin{array}{l}\text { The name of the heat structure } \\
\text { component }\end{array}$ \\
\hline diffusivity & $\begin{array}{l}\text { The name of the diffusivity material } \\
\text { property that will be used in the } \\
\text { flux computation. }\end{array}$ \\
\hline variable & $\begin{array}{l}\text { The name of the flux parameter } \\
\text { (e.g. heat flux) to be integrated }\end{array}$ \\
\hline execute_on & $\begin{array}{l}\text { Set to } \\
\text { (nonlinear /linear|timestep_end|ti } \\
\text { mestep_begin / custom) to execute } \\
\text { only at that moment }\end{array}$ \\
\hline outputs & timestep_end & $\begin{array}{l}\text { The output names (i.e. console, } \\
\text { csv, exodus) for this post- } \\
\text { processor. If none provided then } \\
\text { all specified in [Outputs] will be } \\
\text { used. }\end{array}$ \\
\hline
\end{tabular}

\subsection{Side Integral Variable}

The side integral variable post-processor [SidelntegralVariablePostprocessor] computes the integral of a heat structure component [HeatStructure] surface parameter value.

\begin{tabular}{|c|c|c|}
\hline $\begin{array}{l}\text { Input File Parameters } \\
\text { (Note: Required are bolded) }\end{array}$ & $\begin{array}{c}\text { Parameter Values } \\
\text { (Note: Defaults are bolded) }\end{array}$ & Description \\
\hline$[. /$ name $]$ & Unique name & $\begin{array}{l}\text { Designates sub-block component } \\
\text { name }\end{array}$ \\
\hline type & $\begin{array}{l}\text { SideIntegralVariablePostproc } \\
\text { essor }\end{array}$ & $\begin{array}{l}\text { Designates a side integral variable } \\
\text { post-processor }\end{array}$ \\
\hline boundary & & The name of the heat structure \\
\hline
\end{tabular}




\begin{tabular}{|l|l|l|}
\hline variable & & component \\
\hline execute_on & $\begin{array}{l}\text { The name of the component } \\
\text { parameter to be integrated }\end{array}$ \\
\hline outputs & $\begin{array}{l}\text { Set to } \\
\text { (nonlinear /linear|timestep_end|ti } \\
\text { mestep_begin | custom) to execute } \\
\text { only at that moment }\end{array}$ \\
\hline & $\begin{array}{l}\text { The output names (i.e. console, } \\
\text { csv, exodus) for this post- } \\
\text { processor. If none provided then } \\
\text { all specified in [Outputs] will be } \\
\text { used. }\end{array}$ \\
\hline
\end{tabular}

\subsection{Sum}

The sum post-processor [SumPostprocessor] computes the sum of two post-processors.

\begin{tabular}{|l|l|l|}
\hline \multicolumn{1}{|c|}{ Input File Parameters } & \multicolumn{1}{|c|}{ Parameter Values } & \multicolumn{1}{c|}{ Description } \\
\hline [./note: Required are bolded) & (Note: Defaults are bolded) & $\begin{array}{l}\text { Designates sub-block component } \\
\text { name }\end{array}$ \\
\hline Type & SumPostprocessor & Designates a sum post-processor \\
\hline a & & $\begin{array}{l}\text { Name of first postprocessor whose } \\
\text { value is to summed }\end{array}$ \\
\hline b & $\begin{array}{l}\text { Name of second postprocessor } \\
\text { whose value is to summed }\end{array}$ \\
\hline execute_on & $\begin{array}{l}\text { Set to } \\
\text { (nonlinear /linear|timestep_end|ti } \\
\text { mestep_begin / custom) to execute } \\
\text { only at that moment }\end{array}$ \\
\hline outputs & $\begin{array}{l}\text { The output names (i.e. console, } \\
\text { csv, exodus) for this post- } \\
\text { processor. If none provided then } \\
\text { all specified in [Outputs] will be } \\
\text { used. }\end{array}$ \\
\hline
\end{tabular}

\subsection{Time Step Size}

The time step size post-processor [TimeStepSize] outputs the time step size.

\begin{tabular}{|c|c|c|}
\hline Input File Parameters & \multicolumn{1}{|c|}{ Parameter Values } & \multicolumn{1}{c|}{ Description } \\
(Note: Required are bolded) & (Note: Defaults are bolded) & $\begin{array}{l}\text { Designates sub-block component } \\
\text { name }\end{array}$ \\
\hline [./name] & Unique name & \\
\hline
\end{tabular}




\begin{tabular}{|l|l|l|}
\hline type & TimeStepSize & $\begin{array}{l}\text { Designates a time step size post- } \\
\text { processor }\end{array}$ \\
\hline execute_on & timestep_end & $\begin{array}{l}\text { Set to } \\
\text { (nonlinear } / \text { linear|timestep_end|ti } \\
\text { mestep_begin | custom) to execute } \\
\text { only at that moment }\end{array}$ \\
\hline outputs & $\begin{array}{l}\text { The output names (i.e. console, } \\
\text { csv, exodus) for this post- } \\
\text { processor. If none provided then } \\
\text { all specified in [Outputs] will be } \\
\text { used. }\end{array}$ \\
\hline
\end{tabular}

\subsection{Total Variable Value}

The total variable value size post-processor [TotalVariableValue] sub-block integrates the output value of a post-processor.

\begin{tabular}{|l|l|l|}
\hline \multicolumn{1}{|c|}{ Input File Parameters } & \multicolumn{1}{|c|}{ Parameter Values } & \multicolumn{1}{c|}{ Description } \\
\hline [./note: Required are bolded) & (Note: Defaults are bolded) & $\begin{array}{l}\text { Designates sub-block component } \\
\text { name }\end{array}$ \\
\hline type & Unique name & $\begin{array}{l}\text { Designates a total variable post- } \\
\text { processor }\end{array}$ \\
\hline execute_on & TotalVariableValue & $\begin{array}{l}\text { Set to } \\
\text { (nonlinear |linear|timestep_end|ti } \\
\text { mestep_begin / custom) to execute } \\
\text { only at that moment }\end{array}$ \\
\hline outputs & timestep_end & $\begin{array}{l}\text { The output names (i.e. console, } \\
\text { csv, exodus) for this post- } \\
\text { processor. If none provided then } \\
\text { all specified in [Outputs] will be } \\
\text { used. }\end{array}$ \\
\hline value & $\begin{array}{l}\text { The name of the postprocessor } \\
\text { whose output value is to be } \\
\text { integrated }\end{array}$ \\
\hline
\end{tabular}




\subsection{EXECUTIONER}

The executioner [Executioner] block specifies either the input file as either a transient [Transient] or a control logic [ControlLogic] execution, and includes parameters and values related to time step selection and solver tolerances.

Other executioners and options are included in RELAP-7 but are not specified here.

In the following sections the input file parameters for the [Executioner] blocks and sub-blocks are listed.

\subsection{Transient}

The transient [Transient] sub-block specifies most of the parameters that control a transient execution.

\begin{tabular}{|c|c|c|}
\hline $\begin{array}{l}\text { Input File Parameters } \\
\text { (Note: Required are bolded) }\end{array}$ & $\begin{array}{c}\text { Parameter Values } \\
\text { (Note: Defaults are bolded) }\end{array}$ & Description \\
\hline type & Transient & $\begin{array}{l}\text { Designates execution of a } \\
\text { transient problem }\end{array}$ \\
\hline $\mathrm{dt}$ & 1 & $\begin{array}{l}\text { The time step size between solves } \\
\text { if the adaptive time step option is } \\
\text { not used }\end{array}$ \\
\hline dtmax & $1 e+30$ & $\begin{array}{l}\text { The maximum time step size in an } \\
\text { adaptive run. As an option this } \\
\text { can be specified to control output } \\
\text { file size. }\end{array}$ \\
\hline dtmin & $\begin{array}{l}1 \mathrm{e}-04 \\
2 \mathrm{e}-14\end{array}$ & $\begin{array}{l}\text { The minimum time step size in an } \\
\text { adaptive run. The recommended } \\
\text { value is } 1 \mathrm{e}-04 .\end{array}$ \\
\hline end_time & $1 \mathrm{e}+30$ & $\begin{array}{l}\text { The end time of the simulation is } \\
\text { to be determined based on } \\
\text { problem-specific considerations. }\end{array}$ \\
\hline I_max_its & $\begin{array}{l}100 \\
10000\end{array}$ & $\begin{array}{l}\text { Maximum number of linear } \\
\text { iterations. The recommended } \\
\text { value is } 100 .\end{array}$ \\
\hline I_tol & $\begin{array}{l}1 e-02 \\
1 e-05\end{array}$ & $\begin{array}{l}\text { Linear iteration tolerance. The } \\
\text { recommended value is } 1 \mathrm{e}-02 \text {. }\end{array}$ \\
\hline nl_abs_tol & $\begin{array}{l}1 e-04 \\
1 e-50\end{array}$ & $\begin{array}{l}\text { Non-linear iteration absolute } \\
\text { tolerance. The recommended } \\
\text { value is } 1 \mathrm{e}-04 \text {. }\end{array}$ \\
\hline nl_max_its & $\begin{array}{l}10 \\
50\end{array}$ & $\begin{array}{l}\text { Maximum number of non-linear } \\
\text { iterations. The recommended } \\
\text { value is } 10 .\end{array}$ \\
\hline nl_rel_tol & $\begin{array}{l}1 e-06 \\
1 e-08\end{array}$ & $\begin{array}{l}\text { Non-linear iteration relative } \\
\text { tolerance. The recommended }\end{array}$ \\
\hline
\end{tabular}




\begin{tabular}{|l|l|l|}
\hline & & value is 1e-06. \\
\hline scheme & $\begin{array}{l}\text { 1) bdf2 } \\
\text { 2) implicit-euler }\end{array}$ & $\begin{array}{l}\text { The backward difference time } \\
\text { integration scheme (bdf2) is } \\
\text { recommended }\end{array}$ \\
\hline start_time & $\mathbf{0}$ & $\begin{array}{l}\text { The start time of the simulation is } \\
\text { time zero. }\end{array}$ \\
\hline
\end{tabular}

\subsubsection{Time Stepper}

The time stepper [TimeStepper\} sub-block specifies the time advancement for the numerical method.

\begin{tabular}{|c|l|l|}
\hline \multicolumn{1}{|c|}{ Input File Parameters } & \multicolumn{1}{|c|}{ Parameter Values } & \multicolumn{1}{c|}{ Description } \\
\hline [./name] & (Note: Defaults are bolded) & $\begin{array}{l}\text { Specifies the time stepper sub- } \\
\text { block }\end{array}$ \\
\hline type & $\begin{array}{l}\text { 1) SolutionTimeAdaptiveDT } \\
\text { 2) FunctionDT } \\
\text { 3) ConstantDT }\end{array}$ & $\begin{array}{l}\text { Specifies the time step option. The } \\
\text { recommended option is the } \\
\text { adaptive time step. The } \\
\text { functionDT is a table of time } \\
\text { (time_t)/time step (time_dt) pairs. }\end{array}$ \\
\hline dt & $\begin{array}{l}\text { Value of first time step for adaptive } \\
\text { time step option, and for the } \\
\text { function option. Constant time } \\
\text { step value for constant option. }\end{array}$ \\
\hline percent_change & $\begin{array}{l}\text { This is the percent that the time } \\
\text { step is allowed to change using the } \\
\text { adaptive time step. }\end{array}$ \\
\hline time_t & $\mathbf{0 . 1}$ & \begin{tabular}{l} 
GUl pairs these with "time_dt" \\
\hline
\end{tabular} \\
\hline
\end{tabular}

\subsubsection{Quadrature}

The quadrature [Quadrature] sub-block specifies the type of numerical integration (quadrature) with the two options being trapezoidal and Gaussian (recommended), and the order of the numerical integration with the options being first and second (recommended). For some problems that have stability issues with the recommended quadrature the other option (TRAP/FIRST) may have some benefit.

\begin{tabular}{|l|l|l|}
\hline \multicolumn{1}{|c|}{ Input File Parameters } & \multicolumn{1}{|c|}{ Parameter Values } & \multicolumn{1}{c|}{ Description } \\
(Note: Required are bolded) & (Note: Defaults are bolded) & Specifies the Quadrature sub-block \\
\hline type & Quadrature & $\begin{array}{l}\text { Specifies the type of quadrature. } \\
\text { The recommended type is GAUSS } \\
\text { (Gaussian). }\end{array}$ \\
\hline order & $\begin{array}{l}\text { TRAP } \\
\text { GAUSS }\end{array}$ & Specifies the order of the \\
\hline
\end{tabular}




\begin{tabular}{|l|l|l|}
\hline & SECOND & $\begin{array}{l}\text { quadrature. The recommended } \\
\text { order is SECOND. }\end{array}$ \\
\hline
\end{tabular}




\subsection{FUNCTIONS}

The functions block [Functions] provides any functions used by RELAP-7 code such as reactor power as a function of time, pipe flow area as a function of length, or a pressure boundary condition as a function of time. Specific functions are available for selection as sub-blocks.

Other functions are included in RELAP-7 but are not specified here.

In the following sections the input file parameters for the [Functions] sub-blocks are listed.

\subsection{Constant}

The constant function [ConstantFunction] returns a constant value.

\begin{tabular}{|l|l|l|}
\hline \multicolumn{1}{|c|}{$\begin{array}{c}\text { Input File Parameters } \\
\text { (Note: Required are bolded) }\end{array}$} & \multicolumn{1}{|c|}{ Parameter Values } & \multicolumn{1}{c|}{ Description } \\
\hline [./name] & Unique name & $\begin{array}{l}\text { Designates sub-block function } \\
\text { name }\end{array}$ \\
\hline type & ConstantFunction & $\begin{array}{l}\text { Designates function is a constant } \\
\text { function }\end{array}$ \\
\hline value & $\mathbf{0}$ & The constant value \\
\hline
\end{tabular}

\subsection{Linear}

The linear function [LinearFunction] calculates the value from a linear equation $\left(a+b^{*} x\right)$ given constant values of ' $a$ ' and ' $b$ ', and a function ' $x$ '.

\begin{tabular}{|l|l|l|}
\hline \multicolumn{1}{|c|}{$\begin{array}{c}\text { Input File Parameters } \\
\text { (Note: Required are bolded) }\end{array}$} & \multicolumn{1}{|c|}{$\begin{array}{c}\text { Parameter Values } \\
\text { (Note: Defaults are bolded) }\end{array}$} & $\begin{array}{l}\text { Description } \\
\text { name }\end{array}$ \\
\hline t./name] & Unique name & $\begin{array}{l}\text { Designates function is a linear } \\
\text { function }\end{array}$ \\
\hline a & LinearFunction & The constant in $a+b * x$ \\
\hline b & & The gradient value in $a+b{ }^{*} \mathrm{x}$ \\
\hline x_func & & The $x$ function \\
\hline
\end{tabular}




\subsection{Parsed}

The parsed function calculates a value from a user-defined function consisting of variable/value pairs, numerical values, generic parameters (e.g. " $\mathrm{t}$ " (time), " $\mathrm{x}, \mathrm{y}, \mathrm{z}$ " (coordinates), "pi" ( $\pi$ ), and mathematical functions (e.g. "sin' for sine). Refer to

http://warp.povusers.org/FunctionParser/fparser.html\#functionsyntax for a complete list of syntax.

\begin{tabular}{|c|c|c|}
\hline $\begin{array}{l}\text { Input File Parameters } \\
\text { (Note: Required are bolded) }\end{array}$ & $\begin{array}{c}\text { Parameter Values } \\
\text { (Note: Defaults are bolded) }\end{array}$ & Description \\
\hline$[. /$ name $]$ & Unique name & $\begin{array}{l}\text { Designates sub-block function } \\
\text { name }\end{array}$ \\
\hline type & ParsedFunction & $\begin{array}{l}\text { Designates function is a parsed } \\
\text { function }\end{array}$ \\
\hline value & & $\begin{array}{l}\text { User defined function (equation) } \\
\text { consisting of variables ('vars' with } \\
\text { paired numerical values), numerical } \\
\text { constants, generic parameters (t, x, } \\
y, z, p i) \text {, and mathematical } \\
\text { functions (e.g. 'sin' for sine). Also, } \\
\text { variables can be paired with post- } \\
\text { processor names (as vals), and then } \\
\text { the post-processor output values } \\
\text { are used in the function. }\end{array}$ \\
\hline vals & & $\begin{array}{l}\text { List of numerical values } \\
\text { corresponding to 'vars/vals' pairs. } \\
\text { Also, postprocessor names can be } \\
\text { used and paired to 'vars' variables. }\end{array}$ \\
\hline vars & & $\begin{array}{l}\text { List of variable names (excluding t, } \\
x, y, z) \text { corresponding to 'vars/vals' } \\
\text { pairs used in the function. }\end{array}$ \\
\hline
\end{tabular}

\subsection{Piece-Wise Bi-Linear}

The piece-wise bi-linear [PiecewiseBilinear] function interpolates between pairs of any of the spatial coordinates or time values ( $x, y, z$, or $t$ ) from a user-specified comma-separated (".csv") file. The input parameters designate which of the four types of values are stored in the rows and columns of the ".csv" file. For example, the stored values may be values of ' $x$ ' $v s$. ' $t$ ', or values of ' $y$ ' vs. ' $z$ '. The input files specifies values of pairs of the two selected variables and performs the interpolation.

\begin{tabular}{|l|l|l|}
\hline \multicolumn{1}{|c|}{ Input File Parameters } & \multicolumn{1}{|c|}{ Parameter Values } & \multicolumn{1}{c|}{ Description } \\
(Note: Required are bolded) & \multicolumn{1}{c|}{ (Note: Defaults are bolded) } & \multicolumn{1}{c|}{$\begin{array}{l}\text { Designates sub-block function } \\
\text { name }\end{array}$} \\
\hline [./name] & Unique name & Designates function is a piece-wise \\
\hline type & PiecewiseBilinear &
\end{tabular}




\begin{tabular}{|c|c|c|}
\hline & & bi-linear function \\
\hline axis & 1 & $\begin{array}{l}\text { The first row in the ".csv" file are } \\
\text { spatial data with ('0', ' } 1 \text { ', or ' } 2 \text { ') } \\
\text { designating the ( } x, y, \text { or } z) \\
\text { coordinate. The first column are } \\
\text { values of time. Do not provides } \\
\text { values for 'xaxis' or 'yaxis' } \\
\text { parameters. }\end{array}$ \\
\hline data_file & & Name of file holding .csv data \\
\hline$x$ & & $\begin{array}{l}\text { The } x \text { abscissa values to be } \\
\text { interpolated }\end{array}$ \\
\hline xaxis & 1 & $\begin{array}{l}\text { The first row in the ".csv" file are } \\
\text { spatial data with (' } 0 \text { ', ' } 1 \text { ', or ' } 2 \text { ') } \\
\text { designating the ( } x, y, \text { or } z) \\
\text { coordinate. Do not provide a value } \\
\text { for the 'axis' parameter. A value } \\
\text { for 'yaxis' must be provided. }\end{array}$ \\
\hline y & & $\begin{array}{l}\text { The y abscissa values to be } \\
\text { interpolated }\end{array}$ \\
\hline yaxis & 1 & $\begin{array}{l}\text { The first column in the ".csv" file } \\
\text { are spatial data with }\left(0^{\prime}, \text { ' ' } 1 \text { ', or ' } 2 \text { ') }\right. \\
\text { designating the }(x, y, \text { or } z) \\
\text { coordinate. A value for the 'xaxis' } \\
\text { must be provided. }\end{array}$ \\
\hline z & & $\begin{array}{l}\text { The ordinate values to be } \\
\text { interpolated }\end{array}$ \\
\hline
\end{tabular}

\subsection{Piece-Wise Constant}

The piece-wise constant function [PiecewiseConstant] defines a set of $x / y$ data pairs with no interpolation.

\begin{tabular}{|l|l|l|}
\hline \multicolumn{1}{|c|}{ Input File Parameters } & \multicolumn{1}{|c|}{ Parameter Values } & \multicolumn{1}{c|}{ Description } \\
\hline [./nome] Required are bolded) & (Note: Defaults are bolded) & $\begin{array}{l}\text { Designates sub-block function } \\
\text { name }\end{array}$ \\
\hline type & Unique name & $\begin{array}{l}\text { Designates function is a piecewise } \\
\text { constant function }\end{array}$ \\
\hline axis & PiecewiseConstant & $\begin{array}{l}\text { The axis used }(x, y, \text { or } z \text { ) if this is to } \\
\text { be a function of position }\end{array}$ \\
\hline $\mathrm{x}$ & & \begin{tabular}{l} 
The abscissa values \\
\hline
\end{tabular} \\
\hline
\end{tabular}




\subsection{Piece-Wise Linear}

The piece-wise linear function [PiecewiseLinear] linearly interpolates between values of $(x, y)$ data pairs.

\begin{tabular}{|c|c|c|}
\hline $\begin{array}{l}\text { Input File Parameters } \\
\text { (Note: Required are bolded) }\end{array}$ & $\begin{array}{c}\text { Parameter Values } \\
\text { (Note: Defaults are bolded) }\end{array}$ & Description \\
\hline$[. /$ name $]$ & Unique name & $\begin{array}{l}\text { Designates sub-block function } \\
\text { name }\end{array}$ \\
\hline type & PiecewiseLinear & $\begin{array}{l}\text { Designates function is a piecewise } \\
\text { linear function }\end{array}$ \\
\hline axis & & $\begin{array}{l}\text { The axis used ( } x y \text { or } z \text { ) if this is to } \\
\text { be a function of position }\end{array}$ \\
\hline $\mathrm{x}$ & & The abscissa values \\
\hline$y$ & & The ordinate values \\
\hline
\end{tabular}

\subsection{Power Profile}

The power profile function [PowerProfileFunction] specifies a standard chopped cosine axial shape and can be used by the [HeatGeneration] and [Subchannel] components.

\begin{tabular}{|l|l|l|}
\hline \multicolumn{1}{|c|}{ Input File Parameters } & \multicolumn{1}{|c|}{ Parameter Values } & \multicolumn{1}{c|}{ Description } \\
\hline [./note: Required are bolded) & (Note: Defaults are bolded) & $\begin{array}{l}\text { Designates sub-block function } \\
\text { name }\end{array}$ \\
\hline type & Unique name & $\begin{array}{l}\text { Designates function is a piecewise } \\
\text { linear function }\end{array}$ \\
\hline component & PowerProfileFunction & $\begin{array}{l}\text { The component (x or y or z) with } \\
\text { the recommended value of ' } 2 \\
\text { corresponding to a vertical fuel } \\
\text { assembly }\end{array}$ \\
\hline length & 2 & $\begin{array}{l}\text { The heated length of the fuel } \\
\text { assembly }\end{array}$ \\
\hline coef & $\mathbf{1}$ & \begin{tabular}{l} 
The axial peaking factor \\
\hline
\end{tabular} \\
\hline
\end{tabular}




\subsection{HEAT STRUCTURE MATERIALS}

The heat structure materials [HeatStructureMaterials] block specifies the RELAP-7 parameters necessary to describe the physical properties of solid materials such as ceramics and metals. The input is specified in solid materials properties [SolidMaterialProperties] sub-blocks for each material type.

In the following table the input file parameters for the [SolidMaterialPropertiess] sub-blocks are listed.

\begin{tabular}{|l|l|l|}
\hline \multicolumn{1}{|c|}{ Input File Parameters } & \multicolumn{1}{|c|}{ Parameter Values } & \multicolumn{1}{c|}{ Description } \\
(Note: Required are bolded) & (Note: Defaults are bolded) & $\begin{array}{l}\text { Designates sub-block solid } \\
\text { material, typically a specific metal } \\
\text { or ceramic }\end{array}$ \\
\hline type & Unique name & $\begin{array}{l}\text { Designates sub-block is solid } \\
\text { material properties }\end{array}$ \\
\hline $\mathrm{Cp}$ & SolidMaterialProperties & Specific heat \\
\hline $\mathrm{k}$ & & Thermal conductivity \\
\hline rho & & Density \\
\hline
\end{tabular}




\subsection{CONTROLS}

The controls [Controls] block specifies the modeling of control systems in RELAP-7 input files. A set of sub-blocks describe specific control system parameters.

All of the controls that are included in RELAP-7 are specified here.

Some of the parameters that are not typically used are not included.

In the following sections the input file parameters for the [Controls] sub-blocks are listed.

\subsection{Get Function Value}

This control [GetFunctionValueControl] is called by an upstream control, and specifies the function that will return the parameter value to be used by the upstream control.

\begin{tabular}{|c|l|l|}
\hline \multicolumn{1}{|c|}{ Input File Parameters } & \multicolumn{1}{|c|}{ Parameter Values } & \multicolumn{1}{c|}{ Description } \\
(Note: Required are bolded) & \multicolumn{1}{|c|}{ (Note: Defaults are bolded) } & Designates sub-block control name \\
\hline [./name] & Unique name & $\begin{array}{l}\text { Designates control is a get function } \\
\text { value control }\end{array}$ \\
\hline type & GetFunctionValueControl & $\begin{array}{l}\text { The name of the function } \\
\text { prescribing a value to be used on a } \\
\text { control }\end{array}$ \\
\hline function & & \\
\hline
\end{tabular}

\subsection{Post-Processor Value}

This control [GetPostprocessorValueControl] specifies the output of a post-processor to be used in a downstream control.

\begin{tabular}{|c|c|c|}
\hline $\begin{array}{l}\text { Input File Parameters } \\
\text { (Note: Required are bolded) }\end{array}$ & $\begin{array}{c}\text { Parameter Values } \\
\text { (Note: Defaults are bolded) }\end{array}$ & Description \\
\hline$[. /$ name $]$ & Unique name & Designates sub-block control name \\
\hline type & $\begin{array}{l}\text { GetPostprocessorValueContr } \\
\text { ol }\end{array}$ & $\begin{array}{l}\text { Designates control is a get post- } \\
\text { processor value control }\end{array}$ \\
\hline postprocessor & & $\begin{array}{l}\text { The name of the post-processor } \\
\text { prescribing a value to be used in a } \\
\text { control }\end{array}$ \\
\hline
\end{tabular}

\subsection{Proportional Integral Derivative}

This control [PIDControl] is used in RELAP-7 to model a proportional integral derivative (PID) control. 


\begin{tabular}{|l|l|l|}
\hline \multicolumn{1}{|c|}{ Input File Parameters } & \multicolumn{1}{|c|}{ Parameter Values } & \multicolumn{1}{c|}{ Description } \\
(Note: Required are bolded) & \multicolumn{1}{|c|}{ (Note: Defaults are bolded) } & \\
\hline [./name] & Unique name & Designates sub-block control name \\
\hline type & PIDControl & Designates control is a PID control \\
\hline initial_value & & $\begin{array}{l}\text { The initial value for the integral } \\
\text { part }\end{array}$ \\
\hline input & & $\begin{array}{l}\text { The name of the control data that } \\
\text { is the input }\end{array}$ \\
\hline K_d & $\begin{array}{l}\text { The coefficient for the derivative } \\
\text { term }\end{array}$ \\
\hline K_i & $\begin{array}{l}\text { The coefficient for the integral } \\
\text { term }\end{array}$ \\
\hline K_p & $\begin{array}{l}\text { The coefficient for the proportional } \\
\text { term }\end{array}$ \\
\hline set_point & $\begin{array}{l}\text { The name of the control data with } \\
\text { the set point }\end{array}$ \\
\hline
\end{tabular}

\subsection{Real Function}

This control [RealFunctionControl] sets the value of a input parameter to the value of a specified function.

\begin{tabular}{|c|c|c|}
\hline $\begin{array}{l}\text { Input File Parameters } \\
\text { (Note: Required are bolded) }\end{array}$ & $\begin{array}{c}\text { Parameter Values } \\
\text { (Note: Defaults are bolded) }\end{array}$ & Description \\
\hline$[. /$ name $]$ & Unique name & Designates sub-block control name \\
\hline type & RealFunctionControl & $\begin{array}{l}\text { Designates control is real function } \\
\text { control }\end{array}$ \\
\hline function & & $\begin{array}{l}\text { The function to use to determine } \\
\text { the value of the specified } \\
\text { parameter. }\end{array}$ \\
\hline parameter & & $\begin{array}{l}\text { The input parameter that will be } \\
\text { assigned the value from the } \\
\text { function }\end{array}$ \\
\hline depends_on & & $\begin{array}{l}\text { The upstream control that this } \\
\text { control relies on (i.e. upstream } \\
\text { control must execute first) }\end{array}$ \\
\hline execute_on & 'initial timestep_end' & $\begin{array}{l}\text { Set to } \\
\text { (nonlinear|linear|timestep_end|ti } \\
\text { mestep_begin (custom) to execute } \\
\text { only at that moment }\end{array}$ \\
\hline
\end{tabular}

\subsection{Set Real Value}

This control [SetRealValueControl] specifies the component and parameter to be controlled, along with 
the control that returns the value of the parameter.

\begin{tabular}{|l|l|l|}
\hline \multicolumn{1}{|c|}{ Input File Parameters } & \multicolumn{1}{|c|}{$\begin{array}{c}\text { Parameter Values } \\
\text { (Note: Required are bolded) }\end{array}$} & \multicolumn{1}{c|}{ Description } \\
\hline [./name] & Unique name & SetRealValueControl \\
\hline type & & $\begin{array}{l}\text { Designates control is a set real } \\
\text { value control }\end{array}$ \\
\hline component & $\begin{array}{l}\text { The name of the component to be } \\
\text { controlled. }\end{array}$ \\
\hline parameter & $\begin{array}{l}\text { The name of the parameter in the } \\
\text { component to be controlled. }\end{array}$ \\
\hline value & $\begin{array}{l}\text { The name of the control that } \\
\text { determines the value to be set in } \\
\text { the component. }\end{array}$ \\
\hline
\end{tabular}

\subsection{Terminate}

This control [TerminateControl] terminates the simulation when the 'output' value of the parameter 'threshold' in a UnitTripContol reaches the specified threshold value.

\begin{tabular}{|c|c|c|}
\hline $\begin{array}{l}\text { Input File Parameters } \\
\text { (Note: Required are bolded) }\end{array}$ & $\begin{array}{c}\text { Parameter Values } \\
\text { (Note: Defaults are bolded) }\end{array}$ & Description \\
\hline$[. /$ name $]$ & Unique name & Designates sub-block control name \\
\hline type & TerminateControl & $\begin{array}{l}\text { Designates control is a terminate } \\
\text { control }\end{array}$ \\
\hline input & & $\begin{array}{l}\text { The name of the UnitTripControl } \\
\text { with the parameter 'threshold' and } \\
\text { its value used for simulation } \\
\text { termination. }\end{array}$ \\
\hline
\end{tabular}

\subsection{Time Function}

This control [TimeFunctionControl] specifies for a component and parameter the control of the value of that parameter using a function that includes time as a variable.

\begin{tabular}{|c|c|c|}
\hline $\begin{array}{l}\text { Input File Parameters } \\
\text { (Note: Required are bolded) }\end{array}$ & $\begin{array}{c}\text { Parameter Values } \\
\text { (Note: Defaults are bolded) }\end{array}$ & Description \\
\hline [./name] & Unique name & Designates sub-block control name \\
\hline type & TimeFunctionControl & $\begin{array}{l}\text { Designates control is a time } \\
\text { function control }\end{array}$ \\
\hline component & & $\begin{array}{l}\text { Name of the component that will } \\
\text { be controlled }\end{array}$ \\
\hline function & & $\begin{array}{l}\text { Name of the function (including } \\
\text { time as a variable) prescribing the }\end{array}$ \\
\hline
\end{tabular}




\begin{tabular}{|l|l|l|}
\hline & & value \\
\hline parameter & & $\begin{array}{l}\text { Name of the parameter in the } \\
\text { component that will be controlled }\end{array}$ \\
\hline
\end{tabular}

\subsection{Time Period}

This control [TimePeriod] controls the enabled/disabled state of objects with time

\begin{tabular}{|l|l|l|}
\hline \multicolumn{1}{|c|}{$\begin{array}{c}\text { Input File Parameters } \\
\text { (Note: Required are bolded) }\end{array}$} & \multicolumn{1}{|c|}{ Parameter Values } & \multicolumn{1}{c|}{ Description } \\
\hline [./name] & Unique name & Designates sub-block control name \\
\hline type & TimePeriod & $\begin{array}{l}\text { Designates control is a time period } \\
\text { control }\end{array}$ \\
\hline depends_on & $\begin{array}{l}\text { The upstream control that this } \\
\text { control relies on (i.e. upstream } \\
\text { control must execute first) }\end{array}$ \\
\hline disable_objects & $\begin{array}{l}\text { A list of objects that are } \\
\text { enabled/disabled when the control } \\
\text { time period starts and ends }\end{array}$ \\
\hline end_time & $\begin{array}{l}\text { The time at which the objects are } \\
\text { disabled }\end{array}$ \\
\hline start_time & $\begin{array}{l}\text { The time at which the objects are } \\
\text { enabled }\end{array}$ \\
\hline
\end{tabular}

\subsection{Unit Trip}

This control [UnitTripControl] specifies the control output value(e.g. post-processor value) that is used as the input value for comparison to the specified value of the threshold (setpoint) parameter.

\begin{tabular}{|l|l|l|}
\hline \multicolumn{1}{|c|}{ Input File Parameters } & \multicolumn{1}{|c|}{ Parameter Values } & \multicolumn{1}{c|}{ Description } \\
\hline [./name] & (Note: Defaults are bolded) & Designates sub-block control name \\
\hline type & Unique name & $\begin{array}{l}\text { Designates control is a unit trip } \\
\text { control }\end{array}$ \\
\hline input & UnitTripControl & $\begin{array}{l}\text { The name of the control output } \\
\text { value that is compared to the } \\
\text { threshold (setpoint) value. }\end{array}$ \\
\hline threshold & $\begin{array}{l}\text { The threshold (setpoint) value that } \\
\text { will actuate a downstream control }\end{array}$ \\
\hline
\end{tabular}

\subsection{AUXILIARY KERNELS}

The auxiliary kernels [AuxKernels] block includes a variety of sub-blocks that are used to calculate 
specific quantities of interest using component parameter output values as inputs, along with constants specified as sub-block inputs. The auxiliary kernel output values can then be used for a variety of purposes.

Other auxiliary kernels are included in RELAP-7 but are not specified here.

In the following sections the input file parameters for the [AuxKernels] sub-blocks are listed.

\subsection{Constant}

The constant auxiliary kernel [ConstantAux] sub-block specifies an input numerical value that is assigned as a component parameter value or a component boundary parameter value in the simulation model.

\begin{tabular}{|l|l|l|}
\hline \multicolumn{1}{|c|}{ Input File Parameters } & \multicolumn{1}{|c|}{ Parameter Values } & \multicolumn{1}{c|}{ Description } \\
\hline [./name] & (Note: Defaults are bolded) & $\begin{array}{l}\text { Designates auxiliary kernel sub- } \\
\text { block name }\end{array}$ \\
\hline type & Unique name & $\begin{array}{l}\text { Designates a constant auxiliary } \\
\text { kernel }\end{array}$ \\
\hline variable & $\begin{array}{l}\text { The name of the component } \\
\text { parameter that the constant value } \\
\text { is assigned to. Only one is } \\
\text { allowed. }\end{array}$ \\
\hline block & $\begin{array}{l}\text { The list of component names for } \\
\text { which the parameter is assigned } \\
\text { the constant value }\end{array}$ \\
\hline boundary & $\begin{array}{l}\text { The list of [Inlet] component } \\
\text { names for which the parameter is } \\
\text { assigned the constant value }\end{array}$ \\
\hline execute_on & $\begin{array}{l}\text { Set to } \\
\text { (nonlinear |linear|timestep_end|ti } \\
\text { mestep_begin / custom) to execute } \\
\text { only at that moment }\end{array}$ \\
\hline value & $\begin{array}{l}\text { The constant value to be assigned } \\
\text { to the specified components. }\end{array}$ \\
\hline
\end{tabular}

\subsection{Function}

The function auxiliary kernel [FunctionAux] sub-block samples a function output value in space and time, as applicable, and assigns it as a component parameter value or a component boundary parameter value in the simulation model.

\section{\begin{tabular}{|l|l} 
Input File Parameters & Parameter Values
\end{tabular}}

\section{Description}




\begin{tabular}{|l|l|l|}
\hline (Note: Required are bolded) & (Note: Defaults are bolded) & $\begin{array}{l}\text { Designates auxiliary kernel sub- } \\
\text { block name }\end{array}$ \\
\hline type & Unique name & $\begin{array}{l}\text { Designates a function auxiliary } \\
\text { kernel }\end{array}$ \\
\hline function & FunctionAux & $\begin{array}{l}\text { The function that provides the } \\
\text { input value in space and time }\end{array}$ \\
\hline variable & $\begin{array}{l}\text { The name of the component } \\
\text { parameter that the function output } \\
\text { value is assigned to. Only one is } \\
\text { allowed. }\end{array}$ \\
\hline block & $\begin{array}{l}\text { The list of component names for } \\
\text { which the parameter is assigned } \\
\text { the function output value }\end{array}$ \\
\hline boundary & $\begin{array}{l}\text { The list of component names } \\
\text { ([IletXX]) for which the parameter } \\
\text { is assigned the function output } \\
\text { value }\end{array}$ \\
\hline execute_on & $\begin{array}{l}\text { Set to } \\
\text { (nonlinear |linear|timestep_end|ti } \\
\text { mestep_begin / custom) to execute } \\
\text { only at that moment }\end{array}$ \\
\hline
\end{tabular}

\subsection{Mach Number}

The Mach number auxiliary kernel [MachNumberAux] calculates the Mach number for a specified component.

\begin{tabular}{|l|l|l|}
\hline \multicolumn{1}{|c|}{ Input File Parameters } & \multicolumn{1}{|c|}{ Parameter Values } & \multicolumn{1}{c|}{ Description } \\
\hline [./note: Required are bolded) & (Note: Defaults are bolded) & $\begin{array}{l}\text { Designates auxiliary kernel sub- } \\
\text { block name }\end{array}$ \\
\hline type & Unique name & $\begin{array}{l}\text { Designates a Mach number } \\
\text { auxiliary kernel }\end{array}$ \\
\hline e & MachNumberAux & $\begin{array}{l}\text { Specific internal energy from the } \\
\text { specified component }\end{array}$ \\
\hline $\mathbf{f p}$ & $\begin{array}{l}\text { The name of the fluid properties } \\
\text { model }\end{array}$ \\
\hline $\mathbf{v}$ & $\begin{array}{l}\text { Specific volume from the specified } \\
\text { component }\end{array}$ \\
\hline variable & $\begin{array}{l}\text { The parameter name assigned to } \\
\text { the Mach number output value } \\
\text { (e.g. 'Mach_number_PipeXX') }\end{array}$ \\
\hline vel & $\begin{array}{l}\text { Fluid velocity from the specified } \\
\text { component }\end{array}$ \\
\hline
\end{tabular}




\begin{tabular}{|l|l|l|}
\hline block & & $\begin{array}{l}\text { The list of component names to be } \\
\text { included in the calculation }\end{array}$ \\
\hline execute_on & linear & $\begin{array}{l}\text { Set to } \\
\text { (nonlinear /linear|timestep_end|ti } \\
\text { mestep_begin /custom) to execute } \\
\text { only at that moment }\end{array}$ \\
\hline
\end{tabular}

\subsection{Material Real}

The material average property auxiliary kernel [MaterialRealAux] outputs component volume-averaged material properties.

\begin{tabular}{|l|l|l|}
\hline \multicolumn{1}{|c|}{ Input File Parameters } & \multicolumn{1}{|c|}{ Parameter Values } & \multicolumn{1}{c|}{ Description } \\
\hline [./name] & (Note: Defaults are bolded) & $\begin{array}{l}\text { Designates auxiliary kernel sub- } \\
\text { block name }\end{array}$ \\
\hline type & Unique name & $\begin{array}{l}\text { Designates a material real auxiliary } \\
\text { kernel }\end{array}$ \\
\hline property & MaterialRealAux & $\begin{array}{l}\text { The material property parameter } \\
\text { name to be averaged }\end{array}$ \\
\hline variable & $\begin{array}{l}\text { The parameter name assigned to } \\
\text { the component average parameter } \\
\text { value (e.g. } \\
\text { 'PipeXX_average_temperature') }\end{array}$ \\
\hline block & $\begin{array}{l}\text { The list of component names to be } \\
\text { included in the calculation }\end{array}$ \\
\hline execute_on & $\begin{array}{l}\text { Set to } \\
\text { (nonlinear /linear|timestep_end|ti } \\
\text { mestep_begin / custom) to execute } \\
\text { only at that moment }\end{array}$ \\
\hline
\end{tabular}

\subsection{Mixture Quantity}

The mixture quantity auxiliary kernel [MixtureQuantityAux] calculates a component mixture quantity from vectors of independent values (that sum to 1.0) and dependent variable values. An example is a vector of independent values (liquid void fraction, vapor void fraction), and dependent variables (liquid density, vapor density).

\begin{tabular}{|l|l|l|}
\hline \multicolumn{1}{|c|}{ Input File Parameters } & \multicolumn{1}{c|}{ Parameter Values } & \multicolumn{1}{c|}{ Description } \\
(Note: Required are bolded) & (Note: Defaults are bolded) & \multicolumn{1}{c|}{} \\
\hline [./name] & Unique name & $\begin{array}{l}\text { Designates auxiliary kernel sub- } \\
\text { block name }\end{array}$ \\
\hline type & MixtureQuantityAux & $\begin{array}{l}\text { Designates a mixture quantity } \\
\text { auxiliary kernel }\end{array}$ \\
\hline a & & Vector of independent parameter \\
\hline
\end{tabular}




\begin{tabular}{|l|l|l|}
\hline & & $\begin{array}{l}\text { names whose values (decimal } \\
\text { values) sum to 1.0 (e.g. liquid void } \\
\text { fraction, vapor void fraction) }\end{array}$ \\
\hline b & $\begin{array}{l}\text { Vector of dependent parameter } \\
\text { values that correspond to the } \\
\text { vector of independent variable } \\
\text { values (e.g. density of liquid, } \\
\text { density of vapor) }\end{array}$ \\
\hline variable & $\begin{array}{l}\text { The parameter name assigned to } \\
\text { the component mixture parameter } \\
\text { value (e.g. } \\
\text { 'PipeXX_mixed_density') }\end{array}$ \\
\hline block & $\begin{array}{l}\text { The list of component names to be } \\
\text { included in the calculation }\end{array}$ \\
\hline execute_on & $\begin{array}{l}\text { Set to } \\
\text { (nonlinear /linear|timestep_end|ti } \\
\text { mestep_begin/custom) to execute } \\
\text { only at that moment }\end{array}$ \\
\hline & linear &
\end{tabular}

\subsection{Prandtl Number}

This auxiliary kernel [PrandtINumberAux] calculates the Prandtl number for a component.

\begin{tabular}{|l|l|l|}
\hline \multicolumn{1}{|c|}{ Input File Parameters } & \multicolumn{1}{|c|}{ Parameter Values } & \multicolumn{1}{c|}{ Description } \\
\hline [./name] & (Note: Defaults are bolded) & $\begin{array}{l}\text { Designates auxiliary kernel sub- } \\
\text { block name }\end{array}$ \\
\hline type & PrandtINumberAux & $\begin{array}{l}\text { Designates a Prandtl number } \\
\text { auxiliary kernel }\end{array}$ \\
\hline e & & $\begin{array}{l}\text { Specific internal energy from the } \\
\text { specified component }\end{array}$ \\
\hline $\mathbf{f p}$ & $\begin{array}{l}\text { The name of the fluid properties } \\
\text { model }\end{array}$ \\
\hline variable & $\begin{array}{l}\text { Specific volume from the specified } \\
\text { component }\end{array}$ \\
\hline block & $\begin{array}{l}\text { The parameter name assigned to } \\
\text { the Prandtl number output value } \\
\text { (e.g. 'Prandtl_number_PipeXX') }\end{array}$ \\
\hline execute_on & $\begin{array}{l}\text { The list of component names to be } \\
\text { included in the calculation. If none } \\
\text { are specified then all will be } \\
\text { included. }\end{array}$ \\
\hline & linear & $\begin{array}{l}\text { Set to } \\
\text { (nonlinear |linear|timestep_end|ti } \\
\text { mestep_begin / custom) to execute } \\
\text { only at that moment }\end{array}$ \\
\hline
\end{tabular}




\subsection{Reynolds Number}

This auxiliary kernel [ReynoldsNumberAux] calculates the Reynolds number for a component.

\begin{tabular}{|c|c|c|}
\hline $\begin{array}{l}\text { Input File Parameters } \\
\text { (Note: Required are bolded) }\end{array}$ & $\begin{array}{c}\text { Parameter Values } \\
\text { (Note: Defaults are bolded) }\end{array}$ & Description \\
\hline$[. /$ name $]$ & Unique name & $\begin{array}{l}\text { Designates auxiliary kernel sub- } \\
\text { block name }\end{array}$ \\
\hline type & ReynoldsNumberAux & $\begin{array}{l}\text { Designates a Reynolds number } \\
\text { auxiliary kernel }\end{array}$ \\
\hline D_h & & $\begin{array}{l}\text { Hydraulic diameter from the } \\
\text { specified component }\end{array}$ \\
\hline e & & $\begin{array}{l}\text { Specific internal energy from the } \\
\text { specified component }\end{array}$ \\
\hline$f p$ & & $\begin{array}{l}\text { The name of the fluid properties } \\
\text { model }\end{array}$ \\
\hline rho & & $\begin{array}{l}\text { Density from the specified } \\
\text { component }\end{array}$ \\
\hline $\mathbf{v}$ & & $\begin{array}{l}\text { Specific volume from the specified } \\
\text { component }\end{array}$ \\
\hline variable & & $\begin{array}{l}\text { The parameter name assigned to } \\
\text { the Reynolds number output value } \\
\text { (e.g. 'Reynolds_number_PipeXX') }\end{array}$ \\
\hline vel & & $\begin{array}{l}\text { Velocity from the specified } \\
\text { component }\end{array}$ \\
\hline alpha & 1.0 & $\begin{array}{l}\text { Liquid void fraction from the } \\
\text { specified component }\end{array}$ \\
\hline block & & $\begin{array}{l}\text { The list of component names to be } \\
\text { included in the calculation }\end{array}$ \\
\hline execute_on & linear & $\begin{array}{l}\text { Set to } \\
\text { (nonlinear|linear|timestep_end|ti } \\
\text { mestep_begin|custom) to execute } \\
\text { only at that moment }\end{array}$ \\
\hline
\end{tabular}

\subsection{Sound Speed}

The sound speed auxiliary kernel [SoundSpeedAux] calculates the speed of sound as a function of specific internal energy and specific volume for a component.

\begin{tabular}{|l|l|l|}
\hline \multicolumn{1}{|c|}{ Input File Parameters } & \multicolumn{1}{|c|}{ Parameter Values } & \multicolumn{1}{c|}{ Description } \\
(Note: Required are bolded) & (Note: Defaults are bolded) & $\begin{array}{l}\text { Designates auxiliary kernel sub- } \\
\text { block name }\end{array}$ \\
\hline [./name] & Unique name & Designates a sound speed auxiliary \\
\hline type & SoundSpeedAux &
\end{tabular}




\begin{tabular}{|l|l|l|}
\hline $\mathbf{e}$ & & kernel \\
\hline $\mathbf{f p}$ & & $\begin{array}{l}\text { Specific internal energy from the } \\
\text { specified component }\end{array}$ \\
\hline $\mathbf{v}$ & $\begin{array}{l}\text { The name of the fluid properties } \\
\text { model }\end{array}$ \\
\hline variable & $\begin{array}{l}\text { Specific volume from the specified } \\
\text { component }\end{array}$ \\
\hline block & $\begin{array}{l}\text { The parameter name assigned to } \\
\text { the speed of sound output value } \\
\text { (e.g. 'Sound_speed_PipeXX') }\end{array}$ \\
\hline execute_on & $\begin{array}{l}\text { The list of component names to be } \\
\text { included in the calculation }\end{array}$ \\
\hline & linear & $\begin{array}{l}\text { Set to } \\
\text { (nonlinear/linear|timestep_end } \mid \text { ti } \\
\text { mestep_begin/custom) to execute } \\
\text { only at that moment }\end{array}$ \\
\hline
\end{tabular}

\subsection{Saturation Temperature}

The saturation temperature auxiliary kernel [TemperatureSaturationAux] calculates saturation temperature from pressure for a component.

\begin{tabular}{|c|c|c|}
\hline $\begin{array}{c}\text { Input File Parameters } \\
\text { (Note: Required are bolded) }\end{array}$ & $\begin{array}{c}\text { Parameter Values } \\
\text { (Note: Defaults are bolded) }\end{array}$ & Description \\
\hline$[. /$ name $]$ & Unique name & $\begin{array}{l}\text { Designates auxiliary kernel sub- } \\
\text { block name }\end{array}$ \\
\hline type & TemperatureSaturationAux & $\begin{array}{l}\text { Designates a saturation } \\
\text { temperature auxiliary kernel }\end{array}$ \\
\hline fp & & $\begin{array}{l}\text { The name of the fluid properties } \\
\text { model }\end{array}$ \\
\hline $\mathbf{p}$ & & $\begin{array}{l}\text { Pressure from the specified } \\
\text { component }\end{array}$ \\
\hline variable & & $\begin{array}{l}\text { The parameter name assigned to } \\
\text { the speed of sound output value } \\
\text { (e.g. 'Tsat_PipeXX') }\end{array}$ \\
\hline block & & $\begin{array}{l}\text { The list of component names to be } \\
\text { included in the calculation }\end{array}$ \\
\hline execute_on & linear & $\begin{array}{l}\text { Set to } \\
\text { (nonlinear|linear|timestep_end|ti } \\
\text { mestep_begin / custom) to execute } \\
\text { only at that moment }\end{array}$ \\
\hline
\end{tabular}




\subsection{COMPONENTS}

The components [Components] block specifies within sub-blocks the parameters used for each of the component types used in RELAP-7 simulation models. In RELAP-7 the terminology 'component' refers to a zero, one, or two-dimensional element of a fluid system simulation model. A component can represent a physical structure such as a pipe, valve, pump, or heat exchanger. A component can also be a boundary condition such as a pressure sink or a mass flowrate. A network of components is specified to represent the system being simulated using a three-dimensional mesh.

For each component type most of the parameters are required to fully describe the component, although the list of parameters can vary significantly depending on the component type. Parameter values specified generically in the [GlobalParams] block are superseded by specifying componentspecific values.

The input file parameters for each component type are listed in the following sections. Some component parameters that are not typically used are not included.

\subsection{Check Valve}

The check valve [CheckValve] component is similar to a junction component in that it connects two 1D components, such as pipes. The check valve opens when the dynamic pressure difference exceeds an input value, and then reseats by one of three input values indicating reverse flow, or the static or dynamic differential pressure reversal. Forward and reverse loss coefficients and a reference area are inputs. The valve open/close response time is also an input.

\begin{tabular}{|c|c|c|}
\hline $\begin{array}{l}\text { Input File Parameters } \\
\text { (Note: Required are bolded) }\end{array}$ & $\begin{array}{c}\text { Parameter Values } \\
\text { (Note: Defaults are bolded) }\end{array}$ & Description \\
\hline$[. /$ name $]$ & Unique name & $\begin{array}{l}\text { Designates sub-block component } \\
\text { name }\end{array}$ \\
\hline type & CheckValve & $\begin{array}{l}\text { Designates component is a check } \\
\text { valve }\end{array}$ \\
\hline A_ref & & Area \\
\hline back_pressure & & Dynamic $\Delta p$ for the valve to open \\
\hline center & & Geometric center position $(x, y, z)$ \\
\hline initial_status & $\begin{array}{l}\text { OPEN } \\
\text { CLOSE }\end{array}$ & $\begin{array}{l}\text { Initial status - either 'OPEN' or } \\
\text { 'CLOSE' (i.e. closed) }\end{array}$ \\
\hline inputs & & $\begin{array}{l}\text { Name of the 1D component at the } \\
\text { inlet (e.g. 'PipeXX(out)) }\end{array}$ \\
\hline K & & $\begin{array}{l}\text { Forward flow form loss coefficients } \\
\text { at the inlet and at the outlet }\end{array}$ \\
\hline outputs & & Name of the 1D component at the \\
\hline
\end{tabular}




\begin{tabular}{|c|c|c|}
\hline & & outlet (e.g. 'PipeXX(in)) \\
\hline response_time & & Response time to open or close \\
\hline volume & & Volume \\
\hline check_valve_type & $\begin{array}{l}\text { FLOW } \\
\text { STATIC } \\
\text { DYNAMIC }\end{array}$ & $\begin{array}{l}\text { Check valve type: 'FLOW' (close by } \\
\text { flow reversal); 'STATIC' (close by } \\
\text { static } \Delta \mathrm{p} \text { ); 'DYNAMIC' (close by } \\
\text { dynamic } \Delta \mathrm{p} \text { ) }\end{array}$ \\
\hline initial_T & 300 & Initial temperature \\
\hline initial_alpha_vapor & 1 & Initial vapor volume fraction \\
\hline initial_p & 100000 & Initial pressure \\
\hline initial_vel & 0 & Initial velocity \\
\hline K_reverse & & $\begin{array}{l}\text { Reverse flow form loss coefficients } \\
\text { at the inlet and at the outlet }\end{array}$ \\
\hline
\end{tabular}

\subsection{Compressible Valve}

The compressible valve [CompressibleValve] component is used to model relief and safety valves. It is similar to a junction component in that it connects two 1D components, such as pipes. Typically the compressible valve opens when the dynamic $\Delta p$ exceeds an input value, and then reseats when the $\Delta p$ decreases to less than an input value. As an alternative the valve can open based on inlet pressure. Forward and reverse loss coefficients and a reference area are inputs. The valve open/close response time is also an input. Currently the compressible valve component is restricted to vapor flow.

\begin{tabular}{|l|l|l|}
\hline \multicolumn{1}{|c|}{ Input File Parameters } & \multicolumn{1}{|c|}{ Parameter Values } & \multicolumn{1}{c|}{ Description } \\
\hline [./name] & (Note: Defaults are bolded) & $\begin{array}{l}\text { Designates sub-block component } \\
\text { name }\end{array}$ \\
\hline type & Unique name & $\begin{array}{l}\text { Designates component is a } \\
\text { compressible valve }\end{array}$ \\
\hline A_ref & & Area \\
\hline center & & Geometric center position (x, y, z) \\
\hline initial_status & CLOSE & $\begin{array}{l}\text { Initial status of the valve ('OPEN' or } \\
\text { 'CLOSE' (i.e. closed)) }\end{array}$ \\
\hline inputs & & $\begin{array}{l}\text { Name of the 1D component at the } \\
\text { inlet (e.g. 'PipeXX(out)) }\end{array}$ \\
\hline is_actuated_by_physics & & $\begin{array}{l}\text { This parameter is under } \\
\text { development so specify 'false' }\end{array}$ \\
\hline
\end{tabular}




\begin{tabular}{|c|c|c|}
\hline $\begin{array}{l}\text { is_actuated_by_pressure_diff } \\
\text { erence }\end{array}$ & & $\begin{array}{l}\text { 'true' if the valve is actuated by } \Delta p \text {; } \\
\text { 'false' if actuation is by inlet } \\
\text { pressure }\end{array}$ \\
\hline $\mathbf{K}$ & & $\begin{array}{l}\text { Forward flow form loss coefficients } \\
\text { at the inlet and at the outlet }\end{array}$ \\
\hline outputs & & $\begin{array}{l}\text { Name of the 1D component at the } \\
\text { outlet (e.g. 'PipeXX(in)) }\end{array}$ \\
\hline response_time_close & & Response time to close \\
\hline response_time_open & & Response time to open \\
\hline volume & & Volume \\
\hline delta_p_close & $1 \mathrm{e}+100$ & Minimum $\Delta p$ to close \\
\hline delta_p_open & $1 e+100$ & Minimum $\Delta p$ to open \\
\hline initial_T & 300 & Initial temperature \\
\hline initial_alpha_vapor & 1 & Initial vapor volume fraction \\
\hline initial_p & 100000 & Initial pressure \\
\hline initial_vel & 0 & Initial velocity \\
\hline K_reverse & & $\begin{array}{l}\text { Reverse flow form loss coefficients } \\
\text { at the inlet and at the outlet }\end{array}$ \\
\hline valve_action & NO_ACTION & $\begin{array}{l}\text { Valve control action, either 'OPEN' } \\
\text { or 'CLOSE' (i.e. closed), or } \\
\text { 'NO ACTION' }\end{array}$ \\
\hline
\end{tabular}

\subsection{Core Channel}

The core channel [CoreChannel] component is a composite component that models the coolant flow in the reactor and the heat conduction in the fuel heat structure. The heat transfer between the fuel rods and the coolant is fully coupled, and the axial mesh must be consistent. The fuel heat structure can be either cylindrical fuel rods or plates, and can be either 1D or 2D. The fuel rods include the capability to model the fuel, the fuel-to-cladding gap, and the cladding, with include a variable mesh in the solid materials. The materials are provided by the [HeatStructureMaterials] block. The power input is provided from the [PointKinetics] component, or the [PrescribedReactorPower] component.

\begin{tabular}{|c|l|l|}
\hline \multicolumn{1}{|c|}{ Input File Parameters } & \multicolumn{1}{|c|}{ Parameter Values } & \multicolumn{1}{c|}{ Description } \\
(Note: Required are bolded) & (Note: Defaults are bolded) & $\begin{array}{l}\text { Designates sub-block component } \\
\text { name }\end{array}$ \\
\hline [./name] & Unique name & \\
\hline
\end{tabular}




\begin{tabular}{|c|c|c|}
\hline type & CoreChannel & $\begin{array}{l}\text { Designates component is a core } \\
\text { channel }\end{array}$ \\
\hline A & & Area of coolant channel \\
\hline elem_number_of_hs & & $\begin{array}{l}\text { Number of cells in each heat } \\
\text { structure material. For fuel rod this } \\
\text { is from centerline to surface of fuel } \\
\text { pellet, ID of cladding, and OD of } \\
\text { cladding. For a plate this is from } \\
\text { left surface to right surface. }\end{array}$ \\
\hline fuel_type & & 'cylinder' for fuel rod, or 'plate' \\
\hline length & & Total length along the main axis \\
\hline material_hs & & $\begin{array}{l}\text { Name of each of the materials used } \\
\text { in the heat structures (centerline to } \\
\text { surface for cylinder; left to right for } \\
\text { plate) }\end{array}$ \\
\hline n_elems & & Number of cells along the main axis \\
\hline n_heatstruct & & Number of heat structure materials \\
\hline name_of_hs & & $\begin{array}{l}\text { User specified names of each heat } \\
\text { structure }\end{array}$ \\
\hline orientation & & Orientation vector $(x, y, z)$ \\
\hline P_hf & & Heat structure heated perimeter \\
\hline position & & Origin $(x, y, z)$ \\
\hline width_of_hs & & Width of each heat structure \\
\hline D_h & & $\begin{array}{l}\text { Hydraulic diameter of the coolant } \\
\text { channel }\end{array}$ \\
\hline $\mathrm{Hw}$ & & $\begin{array}{l}\text { Optional user-specified single- } \\
\text { phase convective heat transfer } \\
\text { coefficient. Normally this is not } \\
\text { specified and the closures (boiling } \\
\text { curve) are used. }\end{array}$ \\
\hline Hw_liquid & & $\begin{array}{l}\text { Optional user-specified liquid- } \\
\text { phase convective heat transfer } \\
\text { coefficient. Normally this is not } \\
\text { specified and the closures (boiling } \\
\text { curve) are used. }\end{array}$ \\
\hline Hw_vapor & & $\begin{array}{l}\text { Optional user-specified vapor- } \\
\text { phase convective heat transfer }\end{array}$ \\
\hline
\end{tabular}




\begin{tabular}{|c|c|c|}
\hline & & $\begin{array}{l}\text { coefficient. Normally this is not } \\
\text { specified and the closures (boiling } \\
\text { curve) are used. }\end{array}$ \\
\hline PoD & 1 & $\begin{array}{l}\text { Pitch to diameter ratio for fuel rod } \\
\text { lattice }\end{array}$ \\
\hline depth & & Thickness of plate fuel \\
\hline dim_hs & 2 & $\begin{array}{l}\text { Dimension of the mesh used for } \\
\text { the heat structure ' } 2{ }^{\prime}=2 D ;{ }^{\prime} 1{ }^{\prime}= \\
1 D\end{array}$ \\
\hline$f$ & & $\begin{array}{l}\text { Friction factor for the outer surface } \\
\text { of the heat structure }\end{array}$ \\
\hline f_interface & 0 & $\begin{array}{l}\text { Interface (interphase) friction } \\
\text { between liquid and vapor. A user- } \\
\text { specified value will replace the } \\
\text { value provided by the closure. }\end{array}$ \\
\hline$f p$ & & Name of fluid properties \\
\hline fuel_type & PLATE & 'cylinder' or 'plate' \\
\hline heat_transfer_geom & ROD_BUNDLE & $\begin{array}{l}\text { Convective heat transfer based on } \\
\text { a 'pipe' or 'rod bundle' }\end{array}$ \\
\hline initial_T & & $\begin{array}{l}\text { Initial fluid temperature for single- } \\
\text { phase }\end{array}$ \\
\hline initial_T_liquid & & $\begin{array}{l}\text { Initial fluid temperature for the } \\
\text { liquid phase }\end{array}$ \\
\hline initial_T_vapor & & $\begin{array}{l}\text { Initial fluid temperature for the } \\
\text { vapor phase }\end{array}$ \\
\hline initial_Ts & & $\begin{array}{l}\text { Initial temperature for each } \\
\text { material }\end{array}$ \\
\hline initial_alpha_vapor & & Initial vapor volume fraction \\
\hline initial_p & & Initial pressure in the pipe \\
\hline initial_p_liquid & & Initial pressure for the liquid phase \\
\hline initial_p_vapor & & Initial pressure for the vapor phase \\
\hline initial_vel & & Initial velocity for single-phase \\
\hline initial_vel_liquid & & Initial velocity for the liquid phase \\
\hline initial_vel_vapor & & Initial velocity for the vapor phase \\
\hline mesh_disp_gap & 0.02 & $\begin{array}{l}\text { Heat structure mesh offset for post } \\
\text { processing visualization }\end{array}$ \\
\hline
\end{tabular}




\begin{tabular}{|c|c|c|}
\hline n_elems_hs & & $\begin{array}{l}\text { Number of cells in the heat } \\
\text { structure along the main axis. If } \\
\text { none provided it will default to } \\
\text { 'n_elems' }\end{array}$ \\
\hline n_rods & & Number of rods \\
\hline offset & '000' & $\begin{array}{l}\text { Offset of the origin for post- } \\
\text { processing visualization }\end{array}$ \\
\hline power & & $\begin{array}{l}\text { Name of the component that } \\
\text { provides the reactor power } \\
\text { boundary condition }\end{array}$ \\
\hline power_fraction & & $\begin{array}{l}\text { Fraction of reactor power that is } \\
\text { deposited into each material }\end{array}$ \\
\hline power_shape_function & & $\begin{array}{l}\text { A numerical value is applied as an } \\
\text { axial power multiplier (' } 1 \text { ' is an } \\
\text { constant axial power peaking } \\
\text { factor). A value corresponding to a } \\
\text { function name can return an axial } \\
\text { power shape, and/or a fuel } \\
\text { material region radial power shape, } \\
\text { either as linear functions (constant } \\
\text { in time), or as bi-linear functions of } \\
\text { time }\end{array}$ \\
\hline roughness & 0 & $\begin{array}{l}\text { Roughness of the outer surface of } \\
\text { the heat structure }\end{array}$ \\
\hline
\end{tabular}

\subsection{Downcomer}

The BWR downcomer [Downcomer] component connects the feedwater pipe, the separator dryer discharge, the steam dome, and the downcomer outlet. The downcomer is separated into a vapor region above the mixture level, and a liquid region below the mixture level. During a transient the mixture level is tracked. The vapor pressure is the steam dome pressure. The downcomer component is a junction component with volume.

\begin{tabular}{|l|l|l|}
\hline \multicolumn{1}{|c|}{ Input File Parameters } & \multicolumn{1}{|c|}{ Parameter Values } & \multicolumn{1}{c|}{ Description } \\
(Note: Required are bolded) & \multicolumn{1}{c|}{ (Note: Defaults are bolded) } & $\begin{array}{l}\text { Designates sub-block component } \\
\text { name }\end{array}$ \\
\hline type & Unique name & $\begin{array}{l}\text { Designates component is a BWR } \\
\text { downcomer }\end{array}$ \\
\hline A_ref & DownComer & Area \\
\hline K & & $\begin{array}{l}\text { Forward flow form loss coefficients } \\
\text { at the inlet and at the outlet }\end{array}$ \\
\hline center & & Geometric center position $(x, y, z)$ \\
\hline
\end{tabular}




\begin{tabular}{|c|c|c|}
\hline dome_component & & $\begin{array}{l}\text { Steam dome component name to } \\
\text { provide the vapor pressure }\end{array}$ \\
\hline initial_level & & Initial iquid level \\
\hline inputs & & Feedwater pipe component outlet \\
\hline outputs & & Lower plenum component inlet \\
\hline volume & & Volume \\
\hline initial_T & 300 & Initial temperature \\
\hline initial_alpha_vapor & 1 & Initial vapor volume fraction \\
\hline initial_p & 100000 & Initial pressure \\
\hline initial_vel & 0 & Initial velocity \\
\hline K_reverse & & $\begin{array}{l}\text { Reverse flow form loss coefficients } \\
\text { at the inlet and at the outlet }\end{array}$ \\
\hline
\end{tabular}

\subsection{Elbow Pipe}

The elbow pipe [ElbowPipe] component is a pipe component that includes a bend with a radius and an angle.

\begin{tabular}{|l|l|l|}
\hline \multicolumn{1}{|c|}{ Input File Parameters } & \multicolumn{1}{|c|}{ Parameter Values } & \multicolumn{1}{c|}{ Description } \\
(Note: Required are bolded) & (Note: Defaults are bolded) & $\begin{array}{l}\text { Designates sub-block component } \\
\text { name }\end{array}$ \\
\hline type & Unique name & $\begin{array}{l}\text { Designates component is an elbow } \\
\text { pipe }\end{array}$ \\
\hline A & ElbowPipe & Area \\
\hline end_angle & & $\begin{array}{l}\text { Angle at which the curvature of the } \\
\text { pipe ends }\end{array}$ \\
\hline fp & \begin{tabular}{l} 
Name of fluid properties \\
\hline $\mathbf{n}$ _elems
\end{tabular} & $\begin{array}{l}\text { The number of cells along the main } \\
\text { axis }\end{array}$ \\
\hline orientation & Orientation vector $(x, y, z)$ \\
\hline position & & Origin $(x, y, z)$ \\
\hline radius & & $\begin{array}{l}\text { Radius of the curvature to the } \\
\text { centerline of the pipe }\end{array}$ \\
\hline
\end{tabular}




\begin{tabular}{|c|c|c|}
\hline start_angle & & $\begin{array}{l}\text { Angle at which the curvature of the } \\
\text { pipe starts }\end{array}$ \\
\hline D_h & & Hydraulic diameter \\
\hline$f$ & & Wall friction \\
\hline f_2phase_mult_liquid & & $\begin{array}{l}\text { Two-phase friction multiplier for } \\
\text { liquid phase }\end{array}$ \\
\hline f_2phase_mult_vapor & & $\begin{array}{l}\text { Two-phase friction multiplier for } \\
\text { vapor phase }\end{array}$ \\
\hline f_interface & & Interface (interphase) friction \\
\hline heat_transfer_geom & PIPE & $\begin{array}{l}\text { Convective heat transfer based on a } \\
\text { pipe }\end{array}$ \\
\hline $\mathrm{Hw}$ & & $\begin{array}{l}\text { Optional user-specified single-phase } \\
\text { convective heat transfer coefficient. } \\
\text { Normally this is not specified and } \\
\text { the closures (boiling curve) are } \\
\text { used. }\end{array}$ \\
\hline Hw_liquid & & $\begin{array}{l}\text { Optional user-specified liquid-phase } \\
\text { convective heat transfer coefficient. } \\
\text { Normally this is not specified and } \\
\text { the closures (boiling curve) are } \\
\text { used. }\end{array}$ \\
\hline Hw_vapor & & $\begin{array}{l}\text { Optional user-specified vapor-phase } \\
\text { convective heat transfer coefficient. } \\
\text { Normally this is not specified and } \\
\text { the closures (boiling curve) are } \\
\text { used. }\end{array}$ \\
\hline initial_T & & Initial temperature \\
\hline initial_T_liquid & & $\begin{array}{l}\text { Initial temperature for the liquid } \\
\text { phase }\end{array}$ \\
\hline initial_T_vapor & & $\begin{array}{l}\text { Initial temperature in for the vapor } \\
\text { phase }\end{array}$ \\
\hline initial_alpha_vapor & & Initial vapor volume fraction \\
\hline initial_p & & Initial pressure for single-phase \\
\hline initial_p_liquid & & Initial pressure for the liquid phase \\
\hline initial_p_vapor & & Initial pressure for the vapor phase \\
\hline initial_vel & & Initial velocity for single-phase \\
\hline initial_vel_liquid & & Initial velocity for the liquid phase \\
\hline
\end{tabular}




\begin{tabular}{|l|l|l|}
\hline initial_vel_vapor & & \\
\hline K_2phase_mult_liquid & & Initial velocity for the vapor phase \\
\hline K_2phase_mult_vapor & $\begin{array}{l}\text { Two-phase form loss multiplier for } \\
\text { liquid }\end{array}$ \\
\hline K_prime & $\begin{array}{l}\text { Two-phase form loss multiplier for } \\
\text { vapor }\end{array}$ \\
\hline P_hf & $\begin{array}{l}\text { Form loss coefficient per unit length } \\
\text { that is used for flow in both } \\
\text { directions }\end{array}$ \\
\hline offset & \begin{tabular}{l} 
Heat flux perimeter \\
\hline q_wall
\end{tabular} & $\begin{array}{l}\text { Offset of the origin for post- } \\
\text { processing visualization }\end{array}$ \\
\hline roughness & $\begin{array}{l}\text { User-spedified wall heat flux. } \\
\text { Normally this is not specified and } \\
\text { the closures (boiling curve) are } \\
\text { used. }\end{array}$ \\
\hline
\end{tabular}

\subsection{Free Boundary}

The free boundary [FreeBoundary] component provides a null boundary condition used for 1D components that must be connected to components at both ends.

\begin{tabular}{|l|l|l|}
\hline \multicolumn{1}{|c|}{ Input File Parameters } & \multicolumn{1}{|c|}{ Parameter Values } & \multicolumn{1}{c|}{ Description } \\
(Note: Required are bolded) & (Note: Defaults are bolded) & \multicolumn{1}{c|}{$\begin{array}{l}\text { Designates sub-block component } \\
\text { name }\end{array}$} \\
\hline type & Unique name & $\begin{array}{l}\text { Designates a free boundary } \\
\text { component }\end{array}$ \\
\hline input & FreeBoundary & $\begin{array}{l}\text { Name of the component connected } \\
\text { to the free boundary component }\end{array}$ \\
\hline
\end{tabular}

\subsection{Heat Exchanger Connector}

The heat exchanger connector [HXConnector] component connects the heat exchanger to the heat structure component and to the pipe component. It also specifies which side of the heat structure the heat exchanger is connected to.

\begin{tabular}{|l|l|l|}
\hline \multicolumn{1}{|c|}{ Input File Parameters } & \multicolumn{1}{|c|}{ Parameter Values } & \multicolumn{1}{c|}{ Description } \\
(Note: Required are bolded) & (Note: Defaults are bolded) & \multicolumn{1}{|c|}{} \\
\hline [./name] & Unique name & $\begin{array}{l}\text { Designates sub-block component } \\
\text { name }\end{array}$ \\
\hline
\end{tabular}




\begin{tabular}{|l|l|l|}
\hline type & HXConnector & $\begin{array}{l}\text { Designates component is a heat } \\
\text { exchanger connector }\end{array}$ \\
\hline hs & & $\begin{array}{l}\text { The name of the heat structure } \\
\text { component }\end{array}$ \\
\hline hs_side & The side of the heat structure \\
\hline pipe & & The name of the pipe component \\
\hline
\end{tabular}

\subsection{Heat Generation}

The heat generation [HeatGeneration] component specifies the component and the material region that heat is generated in, and how that heat is distributed, from a power source originating in a separate component.

\begin{tabular}{|l|l|l|}
\hline \multicolumn{1}{|c|}{ Input File Parameters } & \multicolumn{1}{|c|}{ Parameter Values } & \multicolumn{1}{c|}{ Description. } \\
\hline [./name] & (Note: Defaults are bolded) & $\begin{array}{l}\text { Designates sub-block component } \\
\text { name }\end{array}$ \\
\hline type & Unique name & $\begin{array}{l}\text { Designates a heat generation } \\
\text { component }\end{array}$ \\
\hline block & HeatGeneration & $\begin{array}{l}\text { Name of the heat structure material } \\
\text { region in the component with heat } \\
\text { generation }\end{array}$ \\
\hline hs & & $\begin{array}{l}\text { Name of the heat structure } \\
\text { component with heat generation }\end{array}$ \\
\hline power & $\begin{array}{l}\text { Name of the component that } \\
\text { provides power }\end{array}$ \\
\hline power_fraction & $\begin{array}{l}\text { Fraction of power that is deposited } \\
\text { into each material region }\end{array}$ \\
\hline power_shape_function & $\begin{array}{l}\text { A numerical value is applied as an } \\
\text { axial power multiplier ('1' is an } \\
\text { constant axial power peaking } \\
\text { factor). A value corresponding to a } \\
\text { function name can return an axial } \\
\text { power shape, and/or a fuel material } \\
\text { region radial power shape, either as } \\
\text { linear functions (constant in time), } \\
\text { or as bi-linear functions of time }\end{array}$ \\
\hline
\end{tabular}

\subsection{Heat Structure}

The heat structure (HeatStructure] component models a solid material that conducts energy within the solid, and that convects energy into the adjacent pipe components. The heat structure can be either 1D or $2 \mathrm{D}$, and either a cylinder or plate. It can be a composite of several materials, and can be divided into a mesh. 


\begin{tabular}{|c|c|c|}
\hline $\begin{array}{c}\text { Input File Parameters } \\
\text { (Note: Required are bolded) }\end{array}$ & $\begin{array}{c}\text { Parameter Values } \\
\text { (Note: Defaults are bolded) }\end{array}$ & Description \\
\hline$[. /$ name $]$ & Unique name & $\begin{array}{l}\text { Designates sub-block component } \\
\text { name }\end{array}$ \\
\hline type & HeatStructure & $\begin{array}{l}\text { Designates component is a heat } \\
\text { structure }\end{array}$ \\
\hline hs_type & plate & 'cylinder' or 'plate' \\
\hline length & & Lengths along the main axis \\
\hline materials & & $\begin{array}{l}\text { Material names used in the heat } \\
\text { structures }\end{array}$ \\
\hline n_elems & & Number of cells along the main axis \\
\hline n_part_elems & & $\begin{array}{l}\text { Number of cells in each material. } \\
\text { For a cylinder from the centerline } \\
\text { to the surface of each region. For a } \\
\text { plate from the left side to the right } \\
\text { side. }\end{array}$ \\
\hline names & & $\begin{array}{l}\text { User-specified heat structure } \\
\text { region names (e.g. 'fuel', 'cladding') }\end{array}$ \\
\hline orientation & & Orientation vector $(\mathrm{x}, \mathrm{y}, \mathrm{z})$ \\
\hline position & & Origin $(x, y, z)$ \\
\hline widths & & $\begin{array}{l}\text { Width of each heat structure. For a } \\
\text { cylinder from the centerline to the } \\
\text { surface of each region. For a plate } \\
\text { from the left side to the right side. }\end{array}$ \\
\hline axial_offset & 0 & $\begin{array}{l}\text { Radial distance of the gap at the } \\
\text { interior of an annular fuel cylinder. } \\
\text { Not applicable for plates. }\end{array}$ \\
\hline depth & & Thickness of plate \\
\hline $\operatorname{dim}$ & 2 & $\begin{array}{l}\text { Dimension of the mesh used for } \\
\text { the heat structure ' } 2 \text { ' }=2 D ;{ }^{\prime} 1 \text { ' = } \\
\text { 1D }\end{array}$ \\
\hline initial_T & & Initial temperature \\
\hline num_rods & 1 & $\begin{array}{l}\text { Number of rods represented by } \\
\text { this heat structure. Used as a } \\
\text { multiplier on dimensional inputs. }\end{array}$ \\
\hline offset & '000' & $\begin{array}{l}\text { Offset of the origin for post- } \\
\text { processing visualization }\end{array}$ \\
\hline
\end{tabular}




\subsection{Ideal Pump}

The ideal pump [IdealPump] component is a junction component that provides a mass flow rate boundary condition between two pipe components.

\begin{tabular}{|c|c|c|}
\hline $\begin{array}{c}\text { Input File } \\
\text { Parameters } \\
\text { (Note: } \begin{array}{c}\text { Required are } \\
\text { bolded) }\end{array}\end{array}$ & $\begin{array}{c}\text { Parameter Values } \\
\text { (Note: Defaults are bolded) }\end{array}$ & Description \\
\hline$[. /$ name] & Unique name & $\begin{array}{l}\text { Designates sub-block component } \\
\text { name }\end{array}$ \\
\hline type & IdealPump & $\begin{array}{l}\text { Designates component is an ideal } \\
\text { pump }\end{array}$ \\
\hline$f p$ & & Name of fluid properties \\
\hline inputs & & $\begin{array}{l}\text { Name of the 1D component at the } \\
\text { inlet (e.g. 'PipeXX(out)) }\end{array}$ \\
\hline mass_flow_rate & & Mass flow rate boundary condition \\
\hline outputs & & $\begin{array}{l}\text { Name of the 1D component at the } \\
\text { outlet (e.g. 'PipeXX(in)) }\end{array}$ \\
\hline
\end{tabular}

\subsection{Inlet}

The inlet [Inlet] component provides a flow boundary condition to the inlet of a pipe component. Various combinations of parameters options are available to specify the fluid state. Selection of the parameter combinations need to avoid over-specification.

\begin{tabular}{|c|c|c|}
\hline $\begin{array}{l}\text { Input File Parameters } \\
\text { (Note: Required are bolded) }\end{array}$ & $\begin{array}{c}\text { Parameter Values } \\
\text { (Note: Defaults are bolded) }\end{array}$ & Description \\
\hline$[. /$ name $]$ & Unique name & $\begin{array}{l}\text { Designates sub-block component } \\
\text { name }\end{array}$ \\
\hline type & Inlet & Designates component is an inlet \\
\hline input & & $\begin{array}{l}\text { Name of the } 1 \mathrm{D} \text { component } \\
\text { receiving the flow (e.g. 'PipeXX(in)) }\end{array}$ \\
\hline $\mathrm{H}$ & & Enthalpy for single-phase \\
\hline H_liquid & & Enthalpy for the liquid phase \\
\hline H_vapor & & Enthalpy for the vapor phase \\
\hline T0 & & $\begin{array}{l}\text { Stagnation temperature for single- } \\
\text { phase }\end{array}$ \\
\hline T0_liquid & & $\begin{array}{l}\text { Stagnation temperature for the } \\
\text { liquid phase }\end{array}$ \\
\hline
\end{tabular}




\begin{tabular}{|c|c|c|}
\hline T0_vapor & & $\begin{array}{l}\text { Stagnation temperature for the } \\
\text { vapor phase }\end{array}$ \\
\hline T_liquid & & Temperature of the liquid phase \\
\hline T_vapor & & Temperature of the vapor phase \\
\hline alpha_vapor & & Vapor volume fraction \\
\hline m_dot & & Mass flow rate for single-phase \\
\hline m_dot_liquid & & Mass flow rate of the liquid phase \\
\hline m_dot_vapor & & Mass flow rate of the vapor phase \\
\hline $\mathrm{p}$ & & Pressure \\
\hline p0 & & $\begin{array}{l}\text { Stagnation pressure for single- } \\
\text { phase }\end{array}$ \\
\hline p0_liquid & & $\begin{array}{l}\text { Stagnation pressure for the liquid } \\
\text { phase }\end{array}$ \\
\hline p0_vapor & & $\begin{array}{l}\text { Stagnation pressure for the vapor } \\
\text { phase }\end{array}$ \\
\hline p_liquid & & Pressure for the liquid phase \\
\hline p_vapor & & Pressure for the vapor phase \\
\hline reversible & false & $\begin{array}{l}\text { 'false' for boundary conditions that } \\
\text { provide a fluid mass flow type of } \\
\text { boundary condition. 'true' for } \\
\text { boundary conditions that are } \\
\text { similar to an outlet component, } \\
\text { such as a pressure sink. }\end{array}$ \\
\hline rho & & Density for single-phase \\
\hline rho_liquid & & Density of the liquid phase \\
\hline rho_vapor & & Density of the vapor phase \\
\hline rhou & & Momentum for single-phase \\
\hline rhou_liquid & & Momentum for the liquid phase \\
\hline rhou_vapor & & Momentum for the vapor phase \\
\hline vel & & Velocity for single-phase \\
\hline
\end{tabular}




\begin{tabular}{|l|l|l|}
\hline & & \\
\hline vel_liquid & & Velocity of the liquid phase \\
\hline vel_vapor & & Velocity of the vapor phase \\
\hline
\end{tabular}

\subsection{Junction}

The junction [Junction] component can connect multiple pipes at the inlet and outlet but is restricted to single-phase fluids.

\begin{tabular}{|c|l|l|}
\hline \multicolumn{1}{|c|}{ Input File Parameters } & \multicolumn{1}{|c|}{ Parameter Values } & \multicolumn{2}{c|}{ Description } \\
\hline [./note: Required are bolded) & (Note: Defaults are bolded) & \multicolumn{1}{|c|}{$\begin{array}{l}\text { Designates sub-block component } \\
\text { name }\end{array}$} \\
\hline type & Unique name & Designates component is a junction \\
\hline initial_T & Junction & Initial temperature \\
\hline initial_p & & Initial pressure \\
\hline inputs & & $\begin{array}{l}\text { Names of the 1D components at } \\
\text { the inlet (e.g. 'PipeXX(out)) }\end{array}$ \\
\hline outputs & $\begin{array}{l}\text { Names of the 1D components at } \\
\text { the outlet (e.g. 'PipeXX(in)) }\end{array}$ \\
\hline $\mathrm{K}$ & $\begin{array}{l}\text { Form loss coefficients at the } \\
\text { outlets. If loss coefficients are } \\
\text { different for forward and reverse } \\
\text { flow, then use the volume junction } \\
\text { component. }\end{array}$ \\
\hline
\end{tabular}

\subsection{Outlet}

The outlet [Outlet] component provides a backpressure boundary condition to the outlet of a pipe component. An example would be a pressure sink for a relief valve. There is an option for a reversible outlet with flow at the outlet conditions from the outlet component into the pipe component.

\begin{tabular}{|c|c|c|}
\hline $\begin{array}{l}\text { Input File Parameters } \\
\text { (Note: Required are bolded) }\end{array}$ & $\begin{array}{c}\text { Parameter Values } \\
\text { (Note: Defaults are bolded) }\end{array}$ & Description \\
\hline$[. /$ name $]$ & Unique name & $\begin{array}{l}\text { Designates sub-block component } \\
\text { name }\end{array}$ \\
\hline type & Outlet & Designates component is an outlet \\
\hline input & & $\begin{array}{l}\text { Name of the 1D component at the } \\
\text { inlet that is connected to the }\end{array}$ \\
\hline
\end{tabular}




\begin{tabular}{|c|c|c|}
\hline & & $\begin{array}{l}\text { backpressure boundary condition } \\
\text { (e.g. 'PipeXX(out)) }\end{array}$ \\
\hline$p$ & & Pressure for single-phase \\
\hline p_liquid & & Pressure for the liquid phase \\
\hline p_vapor & & Pressure for the vapor phase \\
\hline reversible & false & $\begin{array}{l}\text { 'true' for a reversible outlet } \\
\text { boundary condition }\end{array}$ \\
\hline
\end{tabular}

\subsection{Pipe}

The pipe [Pipe] component is the fundamental 1D component for modeling a volume of fluid in space. A pipe component connects to only one other $1 \mathrm{D}$ component at each end of the pipe via one of several junction components.

\begin{tabular}{|c|c|c|}
\hline $\begin{array}{l}\text { Input File Parameters } \\
\text { (Note: Required are bolded) }\end{array}$ & $\begin{array}{c}\text { Parameter Values } \\
\text { (Note: Defaults are bolded) }\end{array}$ & Description \\
\hline$[. /$ name $]$ & Unique name & $\begin{array}{l}\text { Designates sub-block component } \\
\text { name }\end{array}$ \\
\hline type & Pipe & Designates component is a pipe \\
\hline A & & $\begin{array}{l}\text { Area can be a constant, or variable } \\
\text { along the length of the pipe using a } \\
\text { function sub-block }\end{array}$ \\
\hline$f p$ & & Name of fluid properties \\
\hline length & & Total length along the main axis \\
\hline n_elems & & Number of cells along the main axis \\
\hline orientation & & Orientation vector $(\mathrm{x}, \mathrm{y}, \mathrm{z})$ \\
\hline position & & Origin $(x, y, z)$ \\
\hline$D_{-} h$ & & Hydraulic diameter \\
\hline $\mathrm{Hw}$ & & $\begin{array}{l}\text { Optional user-specified single-phase } \\
\text { convective heat transfer coefficient. } \\
\text { Normally this is not specified and } \\
\text { the closures (boiling curve) are } \\
\text { used. }\end{array}$ \\
\hline $\mathrm{Hw}$ _liquid & & $\begin{array}{l}\text { Optional user-specified liquid-phase } \\
\text { convective heat transfer coefficient. } \\
\text { Normally this is not specified and }\end{array}$ \\
\hline
\end{tabular}




\begin{tabular}{|c|c|c|}
\hline & & $\begin{array}{l}\text { the closures (boiling curve) are } \\
\text { used. }\end{array}$ \\
\hline Hw_vapor & & $\begin{array}{l}\text { Optional user-specified vapor-phase } \\
\text { convective heat transfer coefficient. } \\
\text { Normally this is not specified and } \\
\text { the closures (boiling curve) are } \\
\text { used. }\end{array}$ \\
\hline K_2phase_mult_liquid & & $\begin{array}{l}\text { Two-phase form loss multiplier for } \\
\text { liquid }\end{array}$ \\
\hline K_2phase_mult_vapor & & $\begin{array}{l}\text { Two-phase form loss multiplier for } \\
\text { vapor }\end{array}$ \\
\hline K_prime & & $\begin{array}{l}\text { Form loss coefficient per unit length } \\
\text { applicable for both forward and } \\
\text { reverse flow }\end{array}$ \\
\hline P_hf & & Heat structure heated perimeter \\
\hline PoD & 1 & $\begin{array}{l}\text { Pitch to diameter ratio for fuel rod } \\
\text { lattice }\end{array}$ \\
\hline T_wall & & Wall temperature \\
\hline$f$ & & Wall friction \\
\hline f_2phase_mult_liquid & & $\begin{array}{l}\text { Two-phase friction multiplier for } \\
\text { liquid phase }\end{array}$ \\
\hline f_2phase_mult_vapor & & $\begin{array}{l}\text { Two-phase friction multiplier for } \\
\text { vapor phase }\end{array}$ \\
\hline f_interface & & $\begin{array}{l}\text { Interface (interphase) friction } \\
\text { between liquid and vapor. A user- } \\
\text { specified value will replace the value } \\
\text { provided by the closure. }\end{array}$ \\
\hline heat_transfer_geom & PIPE & $\begin{array}{l}\text { Convective heat transfer based on a } \\
\text { pipe }\end{array}$ \\
\hline initial_T & & $\begin{array}{l}\text { Initial fluid temperature for single- } \\
\text { phase }\end{array}$ \\
\hline initial_T_liquid & & $\begin{array}{l}\text { Initial fluid temperature for the } \\
\text { liquid phase }\end{array}$ \\
\hline initial_T_vapor & & $\begin{array}{l}\text { Initial fluid temperature for the } \\
\text { vapor phase }\end{array}$ \\
\hline initial_alpha_vapor & & Initial vapor volume fraction \\
\hline initial_p & & Initial pressure for single-phase \\
\hline initial_p_liquid & & Initial pressure for the liquid phase \\
\hline initial_p_vapor & & Initial pressure for the vapor phase \\
\hline
\end{tabular}




\begin{tabular}{|l|l|l|}
\hline initial_vel & & Initial velocity for single-phase \\
\hline initial_vel_liquid & & Initial velocity for the liquid phase \\
\hline initial_vel_vapor & $\mathbf{O N O}^{\prime}$ & Initial velocity for the vapor phase \\
\hline offset & 9_wall & $\begin{array}{l}\text { Offset of the origin for post- } \\
\text { processing visualization }\end{array}$ \\
\hline roughness & $\begin{array}{l}\text { User-spedified wall heat flux. } \\
\text { Normally this is not specified and } \\
\text { the closures (boiling curve) are } \\
\text { used. }\end{array}$ \\
\hline
\end{tabular}

\subsection{Pipe With Heat Structure}

The pipe with heat structure [PipeWithHeatStructure] component is the pipe component with a heat structure attached. The parameters are a combination of the parameters used for the pipe and heat structure components, with the same limitations.

\begin{tabular}{|c|c|c|}
\hline $\begin{array}{l}\text { Input File Parameters } \\
\text { (Note: Required are bolded) }\end{array}$ & $\begin{array}{c}\text { Parameter Values } \\
\text { (Note: Defaults are bolded) }\end{array}$ & Description \\
\hline$[. /$ name $]$ & Unique name & $\begin{array}{l}\text { Designates sub-block component } \\
\text { name }\end{array}$ \\
\hline type & PipeWithHeatStructure & $\begin{array}{l}\text { Designates component is a pipe with } \\
\text { heat structure }\end{array}$ \\
\hline A & & $\begin{array}{l}\text { Area can be a constant, or variable } \\
\text { along the length of the pipe using a } \\
\text { function sub-block }\end{array}$ \\
\hline elem_number_of_hs & & $\begin{array}{l}\text { Number of heat structure cells along } \\
\text { the main axis }\end{array}$ \\
\hline$f p$ & & Name of fluid properties \\
\hline HS_BC_type & adiabatic & $\begin{array}{l}\text { Heat structure surface boundary } \\
\text { condition type. 1) 'adiabatic'; 2) } \\
\text { 'constant_temperature' (uses } \\
\text { parameter 'T'), 3) convective (uses } \\
\text { parameters 'h_amb' and 'T_amb') }\end{array}$ \\
\hline hs_type & PLATE & 'cylinder' or 'plate' \\
\hline initial_Ts & & Initial heat structure temperature \\
\hline length & & $\begin{array}{l}\text { Length of the pipe along the main } \\
\text { axis }\end{array}$ \\
\hline material_hs & & Material names used in the heat \\
\hline
\end{tabular}




\begin{tabular}{|c|c|c|}
\hline & & structure \\
\hline n_elems & & $\begin{array}{l}\text { Number of fluid cells along the main } \\
\text { axis }\end{array}$ \\
\hline orientation & & Orientation vector $(x, y, z)$ \\
\hline position & & Origin of the pipe $(x, y, z)$ \\
\hline radius_i & & The inner radius of the pipe wall \\
\hline width_of_hs & & Thickness of the heat structure \\
\hline D_h & & Hydraulic diameter \\
\hline dim_hs & 2 & $\begin{array}{l}\text { Dimension of the mesh used for the } \\
\text { heat structure ' } 2 \text { ' }=2 D ;{ }^{\prime} 1 \text { ' }=1 D\end{array}$ \\
\hline f & & Wall friction for single-phase \\
\hline f_2phase_mult_liquid & & $\begin{array}{l}\text { Two-phase friction multiplier for } \\
\text { liquid }\end{array}$ \\
\hline f_2phase_mult_vapor & & $\begin{array}{l}\text { Two-phase friction multiplier for } \\
\text { liquid }\end{array}$ \\
\hline f_interface & & Interface (inter-phase) friction \\
\hline h_amb & 0.01 & $\begin{array}{l}\text { Convective heat transfer coefficient } \\
\text { from outer surface to ambient. } \\
\text { Used for 'HS_BC_type' = } \\
\text { 'convective'. }\end{array}$ \\
\hline heat_source_liquid & & Volumetric heat source in liquid \\
\hline heat_source_solid & 0 & Volumetric heat source in solid \\
\hline heat_transfer_geom & PIPE & $\begin{array}{l}\text { Convective heat transfer based on a } \\
\text { pipe }\end{array}$ \\
\hline $\mathrm{Hw}$ & & $\begin{array}{l}\text { Optional user-specified single-phase } \\
\text { convective heat transfer coefficient. } \\
\text { Normally this is not specified and } \\
\text { the closures (boiling curve) are } \\
\text { used. }\end{array}$ \\
\hline Hw_liquid & & $\begin{array}{l}\text { Optional user-specified liquid-phase } \\
\text { convective heat transfer coefficient. } \\
\text { Normally this is not specified and } \\
\text { the closures (boiling curve) are } \\
\text { used. }\end{array}$ \\
\hline Hw_vapor & & $\begin{array}{l}\text { Optional user-specified vapor-phase } \\
\text { convective heat transfer coefficient. } \\
\text { Normally this is not specified and } \\
\text { the closures (boiling curve) are }\end{array}$ \\
\hline
\end{tabular}




\begin{tabular}{|c|c|c|}
\hline & & used. \\
\hline initial_T & & Initial temperature for single-phase \\
\hline initial_T_liquid & & $\begin{array}{l}\text { Initial temperature for the liquid } \\
\text { phase }\end{array}$ \\
\hline initial_T_vapor & & $\begin{array}{l}\text { Initial temperature for the vapor } \\
\text { phase }\end{array}$ \\
\hline initial_alpha_vapor & & Initial vapor volume fraction \\
\hline initial_p & & Initial pressure for single-phase \\
\hline initial_p_liquid & & Initial pressure for the liquid phase \\
\hline initial_p_vapor & & Initial pressure for the vapor phase \\
\hline initial_vel & & Initial velocity for single-phase \\
\hline initial_vel_liquid & & Initial velocity for the liquid phase \\
\hline initial_vel_vapor & & Initial velocity for the vapor phase \\
\hline K_2phase_mult_liquid & & $\begin{array}{l}\text { Two-phase form loss multiplier for } \\
\text { liquid }\end{array}$ \\
\hline K_2phase_mult_vapor & & $\begin{array}{l}\text { Two-phase form loss multiplier for } \\
\text { vapor }\end{array}$ \\
\hline K_prime & & $\begin{array}{l}\text { Form loss coefficient per unit length } \\
\text { applicable for both forward and } \\
\text { reverse flow }\end{array}$ \\
\hline offset & '0 00 0' & $\begin{array}{l}\text { Offset of the origin for post- } \\
\text { processing visualization }\end{array}$ \\
\hline P_hf & & Heat flux perimeter \\
\hline q_wall & & $\begin{array}{l}\text { User-spedified wall heat flux. } \\
\text { Normally this is not specified and } \\
\text { the closures (boiling curve) are } \\
\text { used. }\end{array}$ \\
\hline roughness & 0 & Roughness \\
\hline$T$ & 600 & $\begin{array}{l}\text { Fixed ambient temperature } \\
\text { boundary condition. Used for } \\
\text { 'HS_BC_type' = 'convective'. }\end{array}$ \\
\hline T_amb & 300 & Ambient temperature \\
\hline T_wall & & Wall temperature \\
\hline
\end{tabular}




\subsection{Point Kinetics}

The point kinetics [PointKinetics] component solves the point kinetics equations to determine the change in reactor power. Moderator density or temperature reactivity feedback, and fuel temperature (Doppler) reactivity feedback are included via the [ReactivityFeedback] component. An additional reactivity component, such as control rod reactivity as a function of time can be included.

\begin{tabular}{|c|c|c|}
\hline $\begin{array}{l}\text { Input File Parameters } \\
\text { (Note: Required are bolded) }\end{array}$ & $\begin{array}{c}\text { Parameter Values } \\
\text { (Note: Defaults are bolded) }\end{array}$ & Description \\
\hline$[. /$ name $]$ & Unique name & $\begin{array}{l}\text { Designates sub-block component } \\
\text { name }\end{array}$ \\
\hline type & PointKinetics & $\begin{array}{l}\text { Designates a point kinetics } \\
\text { component }\end{array}$ \\
\hline initial_power & & Initial reactor power \\
\hline ANS_standard & 2005 & $\begin{array}{l}\text { The year of the ANSI/ANS } 5.1 \text { decay } \\
\text { heat standard. Options include } \\
1979,1994 \text {, and } 2005 \text {. }\end{array}$ \\
\hline F_U239 & 1 & $\begin{array}{l}\text { U-239 atoms produced by neutron } \\
\text { capture in U-238 per fission }\end{array}$ \\
\hline F_alpha & '0.970.0300' & $\begin{array}{l}\text { Fraction of fissions from U-235, U- } \\
238 \text {, and Pu-239 for } 1979 \text { ANS } \\
\text { standard; Fractions of fissions from } \\
\text { U-235, U-238, Pu-239, and Pu-241 } \\
\text { for } 1994 \text { and } 2005 \text { ANS standards }\end{array}$ \\
\hline F_gamma & 1 & Multiplier on reactor power \\
\hline$Q$ & 200 & $\begin{array}{l}\text { Total energy in MeV generated per } \\
\text { fission }\end{array}$ \\
\hline beta_over_lambda & 200 & $\begin{array}{l}\text { Delayed neutron fraction divided by } \\
\text { prompt neutron lifetime }\end{array}$ \\
\hline eta_Np239 & 0.419 & $\begin{array}{l}\text { Np-239 decay energy in MeV. The } \\
\text { default is from the ANS standard. }\end{array}$ \\
\hline eta_U239 & 0.474 & $\begin{array}{l}\text { U-239 decay energy in MeV. The } \\
\text { default is from the ANS standard }\end{array}$ \\
\hline$f \_i$ & $\begin{array}{l}\text { '0.038 } 0.2130 .1880 .407 \\
0.1280 .026 \text { ' }\end{array}$ & $\begin{array}{l}\text { Fraction of delayed neutrons per } \\
\text { group. Default values are for } \\
\text { Groups } 1 \text { to } 6 \text { in six-group model. }\end{array}$ \\
\hline feedback_components & & $\begin{array}{l}\text { User-specified name of the } \\
\text { reactivity feedback component }\end{array}$ \\
\hline feedback_reactivity & 0 & $\begin{array}{l}\text { Fuel (Doppler) and moderator } \\
\text { density reactivity feedback }\end{array}$ \\
\hline fission_per_fissile & 1 & Number of fissions per fissile atom \\
\hline lam_Np239 & 3.41e-06 & Np-239 decay constant \\
\hline
\end{tabular}




\begin{tabular}{|c|c|c|}
\hline lam_U239 & 0.000491 & U-239 decay constant \\
\hline lambda & $\begin{array}{l}\text { '0.01270.03170.1150.311 } \\
1.43 .87 '\end{array}$ & $\begin{array}{l}\text { Decay constants for delayed } \\
\text { neutron groups. Default values are } \\
\text { for Groups } 1 \text { to } 6 \text { in six-group } \\
\text { model. }\end{array}$ \\
\hline num_eq_FP & 23 & $\begin{array}{l}\text { Number of fission product } \\
\text { equations. The default is from the } \\
\text { ANS standard. }\end{array}$ \\
\hline num_eq_isotope & 4 & $\begin{array}{l}\text { Number of isotopes tracked. The } \\
\text { default value of ' } 4 \text { ' is for the ANS } \\
1994 \text { and } 2005 \text { standards. The } 1979 \\
\text { ANS standard uses a value of ' } 3 \text { '. }\end{array}$ \\
\hline num_eq_precursor & 6 & $\begin{array}{l}\text { Number of delayed neutron } \\
\text { precursor equations. The default } \\
\text { value ' } 6 \text { ' is for the common form of } \\
\text { the point kinetics equation. }\end{array}$ \\
\hline operating_time & 52 & $\begin{array}{l}\text { Reactor operating time before } \\
\text { shutdown in weeks }\end{array}$ \\
\hline reactivity_func & & $\begin{array}{l}\text { Name of the function that can be } \\
\text { used to include a reactivity vs. time } \\
\text { component of the total reactivity. } \\
\text { An example would be reactivity due } \\
\text { to control rod insertion as a function } \\
\text { of time. }\end{array}$ \\
\hline rho & 0 & $\begin{array}{l}\text { The initial reactivity. For a steady- } \\
\text { state reactor the default value of ' } 0 \text { ' } \\
\text { is applicable. }\end{array}$ \\
\hline
\end{tabular}

\subsection{Prescribed Reactor Power}

The prescribed reactor power [PrescribedReactorPower] component provides a constand value of reactor power, or a function name that returns the reactor power as a function of time.

\begin{tabular}{|c|c|c|}
\hline $\begin{array}{l}\text { Input File Parameters } \\
\text { (Note: Required are bolded) }\end{array}$ & $\begin{array}{c}\text { Parameter Values } \\
\text { (Note: Defaults are bolded) }\end{array}$ & Description \\
\hline$[. /$ name $]$ & Unique name & $\begin{array}{l}\text { Designates sub-block component } \\
\text { name }\end{array}$ \\
\hline type & PrescribedReactorPower & $\begin{array}{l}\text { Designates a prescribed reactor } \\
\text { power component }\end{array}$ \\
\hline function & & $\begin{array}{l}\text { A constant numerical value, or a } \\
\text { user-specified function name that } \\
\text { returns the reactor power as a } \\
\text { function of time. }\end{array}$ \\
\hline
\end{tabular}




\subsection{Pump}

The pump [Pump] component is a junction that increases the pressure (head) by a user-specified value, or by connection to a turbine component that provides shaft work.

\begin{tabular}{|l|l|l|}
\hline \multicolumn{1}{|c|}{ Input File Parameters } & \multicolumn{1}{|c|}{ Parameter Values } & \multicolumn{1}{c|}{ Description } \\
(Note: Required are bolded) & (Note: Defaults are bolded) & $\begin{array}{l}\text { Designates sub-block component } \\
\text { name }\end{array}$ \\
\hline type & Unique name & Designates component is a pump \\
\hline A_ref & Pump & Area \\
\hline fp & & Name of fluid properties \\
\hline initial_p & & Initial pressure \\
\hline inputs & & $\begin{array}{l}\text { Names of the 1D components at the } \\
\text { inlet (e.g. 'PipeXX(out)) }\end{array}$ \\
\hline K_reverse & $\begin{array}{l}\text { Reverse flow form loss coefficients } \\
\text { at the inlet and at the outlet }\end{array}$ \\
\hline outputs & $\begin{array}{l}\text { Names of the 1D components at the } \\
\text { outlet (e.g. 'PipeXX(in)) }\end{array}$ \\
\hline driving_component & $\begin{array}{l}\text { Turbine component name to } \\
\text { provide shaft work }\end{array}$ \\
\hline head & $\begin{array}{l}\text { User-specified constant value of } \\
\text { pump head }\end{array}$ \\
\hline
\end{tabular}

\subsection{Reactivity Feedback}

The reactivity feedback [ReactivityFeedback] component calculates the reactivity feedback due to a change in moderator density (using a table of pairs of values) or using a moderator temperature coefficient of reactivity, and due to a change in the fuel temperature (using a table of pairs of values) or using a fuel temperature (Doppler) coefficient of reactivity. The resulting change in reactivity is then used in the point kinetics component.

\begin{tabular}{|c|c|c|}
\hline $\begin{array}{l}\text { Input File Parameters } \\
\text { (Note: Required are bolded) }\end{array}$ & $\begin{array}{c}\text { Parameter Values } \\
\text { (Note: Defaults are bolded) }\end{array}$ & Description \\
\hline$[. /$ name $]$ & Unique name & $\begin{array}{l}\text { Designates sub-block component } \\
\text { name }\end{array}$ \\
\hline type & ReactivityFeedback & $\begin{array}{l}\text { Designates a reactivity feedback } \\
\text { component }\end{array}$ \\
\hline core_channel & & $\begin{array}{l}\text { User-specified name of the core } \\
\text { channel component that provides } \\
\text { the moderator density and } \\
\text { temperature }\end{array}$ \\
\hline
\end{tabular}




\begin{tabular}{|c|c|}
\hline fuel_block & $\begin{array}{l}\text { In the core channel component, the } \\
\text { user-specified name of the heat } \\
\text { structure material region (e.g. 'fuel') } \\
\text { that provides the fuel temperature }\end{array}$ \\
\hline fuel_temperature & $\begin{array}{l}\text { Fuel material temperatures (axial } \\
\text { cell average values) used as the } \\
\text { independent parameter in a table of } \\
\text { fuel temperature reactivity }\end{array}$ \\
\hline fuel_reactivity & $\begin{array}{l}\text { Fuel temperature (Doppler) } \\
\text { reactivity values from a table of fuel } \\
\text { temperature reactivity }\end{array}$ \\
\hline fuel_temp_coefficient & $\begin{array}{l}\text { Fuel temperature (Doppler) } \\
\text { coefficient of reactivity (constant } \\
\text { value) that is multiplied by a } \\
\text { volumetric average fuel } \\
\text { temperature to obtain the change in } \\
\text { reactivity. }\end{array}$ \\
\hline fuel_weighting_factor & $\begin{array}{l}\text { Weighting factors applied to each } \\
\text { axial cell of the fuel material from } \\
\text { bottom to top, and applied to the } \\
\text { table of fuel temperature reactivity } \\
\text { vs. fuel temperature. Normally } \\
\text { these sum to } 1.0 \text {. }\end{array}$ \\
\hline mod_density & $\begin{array}{l}\text { Moderator (coolant channel) } \\
\text { densities (axial cell average values) } \\
\text { used as the independent parameter } \\
\text { in a table of moderator density } \\
\text { reactivity }\end{array}$ \\
\hline mod_reactivity & $\begin{array}{l}\text { Moderator (coolant channel) } \\
\text { density reactivity values from a } \\
\text { table of moderator (coolant } \\
\text { channel) density reactivity }\end{array}$ \\
\hline mod_temp_coefficient & $\begin{array}{l}\text { Moderator (coolant channel) } \\
\text { temperature coefficient of reactivity } \\
\text { (constant value) that is multiplied by } \\
\text { a volumetric average moderator } \\
\text { (coolant channel) temperature to } \\
\text { obtain the change in reactivity. }\end{array}$ \\
\hline mod_weighting_factor & $\begin{array}{l}\text { Weighting factors applied to each } \\
\text { axial cell of the moderator (coolant } \\
\text { channel) from bottom to top, and } \\
\text { applied to the table of moderator } \\
\text { density reactivity vs. moderator } \\
\text { density. Normally these sum to } 1.0 \text {. }\end{array}$ \\
\hline
\end{tabular}




\subsection{Simple Junction}

The simple junction [SimpleJunction] component is a junction that is only applicable when the two connecting pipes have the same area. This is the only junction that currently can model two-phase flow.

\begin{tabular}{|l|l|l|}
\hline \multicolumn{1}{|c|}{ Input File Parameters } & \multicolumn{1}{|c|}{ Parameter Values } & \multicolumn{1}{c|}{ Description } \\
\hline [./note: Required are bolded) & (Note: Defaults are bolded) & $\begin{array}{l}\text { Designates sub-block component } \\
\text { name }\end{array}$ \\
\hline type & Unique name & $\begin{array}{l}\text { Designates component is a simple } \\
\text { junction }\end{array}$ \\
\hline inputs & SimpleJunction & $\begin{array}{l}\text { Name of the 1D component at the } \\
\text { inlet (e.g. 'PipeXX(out)) }\end{array}$ \\
\hline outputs & $\begin{array}{l}\text { Name of the 1D component at the } \\
\text { outlet (e.g. 'PipeXX(in)) }\end{array}$ \\
\hline
\end{tabular}

\subsection{Solid Wall}

The solid wall [SolidWall] component is a junction used as the boundary condition for a dead-ended pipe component. Therefore there is no flow circulating through the pipe, however the mass in the pipe can change due to coolant expansion or contraction.

\begin{tabular}{|c|c|c|}
\hline $\begin{array}{l}\text { Input File Parameters } \\
\text { (Note: Required are bolded) }\end{array}$ & $\begin{array}{c}\text { Parameter Values } \\
\text { (Note: Defaults are bolded) }\end{array}$ & Description \\
\hline$[. /$ name $]$ & Unique name & $\begin{array}{l}\text { Designates sub-block component } \\
\text { name }\end{array}$ \\
\hline type & SolidWall & $\begin{array}{l}\text { Designates component is a solid } \\
\text { wall }\end{array}$ \\
\hline input & & $\begin{array}{l}\text { Name of the 1D component at the } \\
\text { inlet (e.g. 'PipeXX(out)) }\end{array}$ \\
\hline
\end{tabular}

\subsection{Turbine}

The turbine [Turbine] component is a simplified turbine junction component applicable to a Terry turbine, and not for a large power generation turbine.

\begin{tabular}{|l|l|l|}
\hline \multicolumn{1}{|c|}{ Input File Parameters } & \multicolumn{1}{|c|}{ Parameter Values } & \multicolumn{1}{c|}{ Description } \\
(Note: Required are bolded) & \multicolumn{1}{c|}{ (Note: Defaults are bolded) } & $\begin{array}{l}\text { Designates sub-block component } \\
\text { name }\end{array}$ \\
\hline type & Unique name & Designates component is a turbine \\
\hline fp & Turbine & Name of fluid properties \\
\hline initial_T & & Initial temperature \\
\hline
\end{tabular}




\begin{tabular}{|l|l|l|}
\hline \multicolumn{1}{|c|}{} & & \\
\hline initial_p & Initial pressure \\
\hline inputs & $\begin{array}{l}\text { Name of the 1D component at the } \\
\text { inlet (e.g. 'PipeXX(out)) }\end{array}$ \\
\hline max_mass_flow_rate & \begin{tabular}{l} 
Nominal maximum mass flow rate \\
\hline outputs
\end{tabular} & $\begin{array}{l}\text { Name of the 1D component at the } \\
\text { outlet (e.g. 'PipeXX(in)) }\end{array}$ \\
\hline p0_design & $\begin{array}{l}\text { Nominal design inlet stagnation } \\
\text { pressure }\end{array}$ \\
\hline pressure_ratio_design & $\begin{array}{l}\text { Ratio of pressures at inlet and } \\
\text { outlet for design conditions }\end{array}$ \\
\hline T0_design & $\begin{array}{l}\text { Nominal design inlet stagnation } \\
\text { temperature }\end{array}$ \\
\hline turbine_efficiency & Turbine thermal efficiency \\
\hline
\end{tabular}

\subsection{Valve}

The valve [Valve] component is a junction component connecting two pipe components that opens or closes at a specified time with a specified stroke time.

\begin{tabular}{|c|c|c|}
\hline $\begin{array}{l}\text { Input File Parameters } \\
\text { (Note: Required are bolded) }\end{array}$ & $\begin{array}{c}\text { Parameter Values } \\
\text { (Note: Defaults are bolded) }\end{array}$ & Description \\
\hline$[. /$ name $]$ & Unique name & $\begin{array}{l}\text { Designates sub-block component } \\
\text { name }\end{array}$ \\
\hline type & Valve & Designates component is a valve \\
\hline A_ref & & Area \\
\hline center & & Geometric center position $(x, y, z)$ \\
\hline initial_status & OPEN & $\begin{array}{l}\text { Initial position of the valve 'open' or } \\
\text { 'close' (closed) }\end{array}$ \\
\hline inputs & & $\begin{array}{l}\text { Name of the 1D component at the } \\
\text { inlet (e.g. 'PipeXX(out)) }\end{array}$ \\
\hline K & & $\begin{array}{l}\text { Forward flow form loss coefficients } \\
\text { at the inlet and at the outlet }\end{array}$ \\
\hline outputs & & $\begin{array}{l}\text { Name of the 1D component at the } \\
\text { outlet (e.g. 'PipeXX(in)) }\end{array}$ \\
\hline response_time & & Valve stroke time \\
\hline trigger_time & & $\begin{array}{l}\text { Simulation time the valve is } \\
\text { actuated to change position }\end{array}$ \\
\hline volume & & Volume \\
\hline
\end{tabular}




\begin{tabular}{|l|l|l|}
\hline & & \\
\hline K_reverse & & $\begin{array}{l}\text { Reverse flow form loss coefficients } \\
\text { at the inlet and at the outlet }\end{array}$ \\
\hline initial_T & $\mathbf{3 0 0}$ & Initial temperature \\
\hline initial_alpha_vapor & $\mathbf{1}$ & Initial vapor volume fraction \\
\hline initial_p & $\mathbf{1 0 0 0 0 0}$ & Initial pressure \\
\hline initial_vel & $\mathbf{0}$ & Initial velocity \\
\hline
\end{tabular}

\subsection{Volume Junction}

The volume junction [VolumeJunction] component is a junction component with volume with a unique capability to connect multiple pipe components, which is necessary when flow streams are split or merged. The current model is limited to single-phase conditions. Typical applications would be to model a plenum or a header.

\begin{tabular}{|c|c|c|}
\hline $\begin{array}{l}\text { Input File Parameters } \\
\text { (Note: Required are bolded) }\end{array}$ & $\begin{array}{c}\text { Parameter Values } \\
\text { (Note: Defaults are bolded) }\end{array}$ & Description \\
\hline$[. /$ name $]$ & Unique name & $\begin{array}{l}\text { Designates sub-block component } \\
\text { name }\end{array}$ \\
\hline type & VolumeJunction & $\begin{array}{l}\text { Designates component is a volume } \\
\text { junction }\end{array}$ \\
\hline A_ref & & Reference area \\
\hline center & & Geometric center $(x, y, z)$ \\
\hline inputs & & $\begin{array}{l}\text { Names of the 1D components at the } \\
\text { inlet (e.g. 'PipeXX(out)) }\end{array}$ \\
\hline K & & $\begin{array}{l}\text { Forward flow form loss coefficients } \\
\text { at the inlets and at the outlets }\end{array}$ \\
\hline outputs & & $\begin{array}{l}\text { Names of the 1D components at the } \\
\text { outlet (e.g. 'PipeXX(in)) }\end{array}$ \\
\hline volume & & Volume \\
\hline K_reverse & & $\begin{array}{l}\text { Reverse flow form loss coefficients } \\
\text { at the inlets and at the outlets }\end{array}$ \\
\hline initial_t & 300 & Initial temperature \\
\hline initial_alpha_vapor & 1 & Initial vapor volume fraction \\
\hline initial_p & 100000 & Initial pressure \\
\hline
\end{tabular}




\subsection{Wet Well}

The wet well [WetWell] component is a simplified junction component with a specified gas (e.g. air or nitrogen) over a liquid water pool in a rectangular (cubic) volume representation. The major design features of a BWR wet well suppression pool are included. An example application is to condense the exhaust steam from a Terry turbine. The model is not suitable for large steam flowrates such as a LOCA blowdown.

\begin{tabular}{|c|c|c|}
\hline $\begin{array}{l}\text { Input File Parameters } \\
\text { (Note: Required are bolded) }\end{array}$ & $\begin{array}{c}\text { Parameter Values } \\
\text { (Note: Defaults are } \\
\text { bolded) }\end{array}$ & Description \\
\hline [./name] & Unique name & Designates sub-block component name \\
\hline type & WetWell & Designates component is a BWR wet well \\
\hline Ac & & Average cross sectional area \\
\hline alpha_s & & $\begin{array}{l}\text { Effective heat transfer coefficient for the } \\
\text { gas to water pool interfacial area }\end{array}$ \\
\hline cooling_rate & & $\begin{array}{l}\text { Heat removal rate boundary condition } \\
\text { from an immersed heat exchanger }\end{array}$ \\
\hline fp_nc_gas & & $\begin{array}{l}\text { Name of fluid properties for the non- } \\
\text { condensible gas }\end{array}$ \\
\hline fp_vapor & & Name of fluid properties for vapor \\
\hline fp_water & & Name of fluid properties for water \\
\hline initial_Lw & & Initial water level \\
\hline initial_T & & Initial gas and water temperature \\
\hline initial_p_gas & & Initial gas pressure \\
\hline inputs & & $\begin{array}{l}\text { Steam sources to the wet well (e.g. } \\
\text { turbine exhaust steam) }\end{array}$ \\
\hline Lt & & Total effective height of the wet well \\
\hline outputs & & $\begin{array}{l}\text { Dry well that is connected to gas venting } \\
\text { line (e.g. an outlet component) }\end{array}$ \\
\hline z_in & & $\begin{array}{l}\text { Inlet steam pipe discharge elevation } \\
\text { above the pool bottom }\end{array}$ \\
\hline z_out & & $\begin{array}{l}\text { Outlet water pipe inlet elevation above } \\
\text { the pool bottom }\end{array}$ \\
\hline K_i & 1 & $\begin{array}{l}\text { Forward flow form loss coefficient for } \\
\text { steam inlet pipe }\end{array}$ \\
\hline K_ir & 0.5 & Reverse flow form loss coefficient for \\
\hline
\end{tabular}




\begin{tabular}{|l|l|l|}
\hline & & steam inlet pipe \\
\hline K_o & $\mathbf{0 . 5}$ & $\begin{array}{l}\text { Forward flow form loss coefficient for } \\
\text { water outlet pipe }\end{array}$ \\
\hline K_or & $\mathbf{0 . 5}$ & $\begin{array}{l}\text { Reverse flow form loss coefficient for } \\
\text { water outlet pipe }\end{array}$ \\
\hline K_v & $\mathbf{0 . 5}$ & $\begin{array}{l}\text { Forward flow form loss coefficient for gas } \\
\text { venting line to dry well }\end{array}$ \\
\hline K_vr & $\mathbf{1}$ & $\begin{array}{l}\text { Reverse flow form loss coefficient for gas } \\
\text { venting line to drywell }\end{array}$ \\
\hline number_of_steam_lines & $\mathbf{1}$ & Number of steam injection lines \\
\hline
\end{tabular}

